Wirtschaftswissenschaftliche

Fakultät

\title{
Towards a More Nuanced Understanding of How International Pooling of Authority May Affect the Perceived Legitimacy of Global Governance
}


Towards a More Nuanced Understanding of How International Pooling of Authority May

\title{
Affect the Perceived Legitimacy of Global Governance
}

Brilé Anderson *, Thomas Bernauer ${ }^{+}$, Aya Kachi ”

September 2017

* OECD, Climate, Biodiversity and Water Division in the Environmental Directorate

+ ETH Zurich, Institute of Science, Technology and Policy, corresponding author: thbe0520@ethz.ch

“ University of Basel, Faculty of Business and Economics

\begin{abstract}
:
Recent instances of political backlash against global governance efforts as well as conventional wisdom suggest that there is a link between shifting authority from the domestic to the global level, on the one hand, and the legitimacy of global governance institutions as perceived by citizens and other stakeholders on the other. We thus investigate whether and how increasing the authority of a global governance institution affects citizens' legitimacy perceptions, using a population-based survey experiment in Germany and the United States ( $\mathrm{N}=1600$ each). The empirical focus is on climate change, a costly and paradigmatic global governance effort. The results show that certain shifts of political authority, such as changes to majority decision making at the international level and automatic implementation of international decisions domestically, do not significantly affect “average" citizens' legitimacy perceptions of global governance institutions. This result is not due to citizens' incapacity to understand the implications of increasing authority, namely, that increasing authority results in a loss of control over climate policy in Germany and the United States. Rather, legitimacy perceptions appear to be shaped by citizens' perceptions of procedural and performance quality of such efforts as well as by their level of cognitive mobilization, namely their interest in international politics. In brief, we find that citizens relate perceived procedural and performance quality of global governance with their evaluation of its legitimacy, but that subtle shifts of authority from the domestic to the global level do not per se affect citizens’ legitimacy perceptions.
\end{abstract}

\section{Acknowledgements:}

The research for this paper was funded by the ERC Advanced Grant 'Sources of Legitimacy in Global Environmental Governance’ (Grant: 295456) and supported by ETH Zürich. We are grateful for comments by Michael Zürn, Jonas Tallberg, Zorzeta Bakaki, Mike Hudecheck, Vally Koubi, Liam McGrath, Quynh Nguyen, Irina Shaymerdenova, and Mike Tomz on earlier versions of this paper. 


\section{Introduction}

Many observers of international politics link the authority of a global governance institution with its legitimacy as perceived by citizens and other stakeholders. In constructing this link, they usually surmise that as the authority of a global governance institution increases, perceptions of its legitimacy decline unless the institution continues to meet citizens' and stakeholders’ procedural and performance standards (Zürn, Binder, and Ecker-Erdhardt Zürn 2012; 2015; Tallberg and Zürn (this volume). A contemporary example of this hypothesized link is Brexit, where in June 2016, 52 percent of Britons voted to leave the EU. One common post hoc explanation of this event is that Brexit was catalyzed by the mounting frustration of Britons with Brussels' influence over British politics and law, particularly in regards to immigration policy and its perceived impact on the British economy. Despite the ubiquity of this authority-legitimacy argument, it remains open to debate whether the loss of the EU's legitimacy amongst Britons in fact occurred as a direct result of the EU's increasing authority, or because of other factors, such as elite cues. In this paper, we delve deeper into this presumed link between the authority of a global governance institution and its legitimacy in order to better understand the formation of citizens' legitimacy perceptions of such institutions. By global governance institution, we mean a formal, multilateral and organizational or administrative arrangement, such as an international organization, as well as private, bilateral or informal pacts. We investigate to what extent and how the authority of global governance institutions affects citizens’ legitimacy perceptions if at all.

The existing literature offers limited insights into the link between the authority of global governance institutions and citizens’ legitimacy perceptions concerning such institutions. Prior work on the formation of citizens' legitimacy perceptions tends to measure concepts related to legitimacy such as citizens’ support, confidence or trust, but not legitimacy directly (Gibson and Caldeira 1995; Norris 2000; Hessami 2011; Voeten 2013; Dellmuth and Tallberg 2015). In addition, previous 
research on the effects of authority on citizens' legitimacy perceptions uses observational study designs, making it challenging to parse out causal effects of authority on legitimacy perceptions from other factors, such as heuristics (Della Porta et al. 2006; Levi and Murphy 2006; Dellmuth and Tallberg this volume; Dingwerth, Schmidtke, and Weise this volume). As a result, it remains open whether citizens even understand the implications of transferring authority to a global governance institution and if such transfer, in turn, affect their legitimacy perceptions.

We contribute to this literature in at least three ways. First, we seek to disentangle competing theories on the formation of citizens' legitimacy perceptions. The most prominent theory, in contrast to the "link" hypothesis, is that ordinary citizens have underdeveloped attitudes towards global governance institutions because they are either incapable or uninterested in evaluating the institutions' authority. Instead, citizens use heuristics, such as communication from domestic and international elites, to develop their legitimacy perceptions, often bypassing fact-based evaluations of an institution's authority (Dellmuth and Tallberg, this volume). Our experimental study thus assesses whether increasing the authority of an institution has any direct effects on citizens' legitimacy perceptions. We also look into whether citizens understand the implications of varying levels of authority, and how they form their legitimacy perceptions under these conditions. We thus seek to assess the empirical relevance of two competing explanations of citizens' legitimacy belief formation: (1) that citizens are in fact ignorant and incapable of assessing the authority of global governance institutions; or (2) that shifts of authority actually do or do not influence individuals' legitimacy perceptions directly.

Second, our study sheds light on potential differences in the authority-legitimacy link as formed by different types of citizens. Since individual-level characteristics are likely to matter for citizens’ legitimacy perceptions (see Hooghe and Marks 2005; Edwards 2009; Hooghe and Marks 2009; Johnson 2011; Ecker-Erhardt 2012; Voeten 2013; Chalmers and Dellmuth 2015; Dellmuth and Tallberg 2015; Schlipphak 2015), the effect of authority on legitimacy perceptions should also vary 
by individuals' characteristics (Zürn and Tallberg, this volume). Building on the aforementioned "incapable citizens" argument, we theorize that the authority of a global governance institution should affect citizens' legitimacy perceptions more directly and to a larger extent if citizens are more cognitively mobilized (i.e. those more interested in international politics).

Our third contribution to the existing literature is that we examine the authority-legitimacy link based on an experimental, rather than an observational study design. It is widely argued that many legitimation efforts by international organizations are necessary precisely because of their increasing authority (which supposedly diminishes perceived legitimacy amongst citizens). To assess the presumed causality between authority and legitimacy, an experimental approach with interventions associated with varying level of authority (see Section 3.1) is useful. Building on the typology by Hooghe and Marks (2015), we conceptualize authority on two dimensions: voting rules in international negotiations to create a climate change agreement (consensus or majority voting), and the domestic implementation procedures (automatic implementation at the domestic level or implementation after ratification by the national legislature). This results in four stylized climate governance frameworks (2x2 design) with differing levels of authority, which are randomly assigned to study participants. The dependent variable captures perceived legitimacy of the climate governance framework, a paradigmatic global governance effort that possesses relatively little authority at present. Our experiment was embedded in a survey with nationally representative samples from Germany and the United States ( $\mathrm{N}=1600$ each).

The results show that even important shifts of authority, such as majority decision making at the international level and automatic implementation of international decisions domestically, do not significantly and directly affect citizens' legitimacy perceptions on average. They also show that this insignificant effect is not due to citizens' inability to assess the authority of the climate governance framework. In fact, citizens clearly understand the implications of increased authority; namely, that it results in a loss of national control over climate policy. However, we find that amongst cognitively 
mobilized individuals (i.e. those who are more interested in international politics and hence are more likely to be sensitive to nuanced institutional differences), increased authority increases perceived legitimacy. We also find that legitimacy perceptions are significantly correlated with citizens' assessments of procedural and performance quality, though our experimental manipulations of authority do not significantly affect citizens' perceptions of performance and procedural quality. This finding may at least partially explain why variation in authority has no direct effect on citizens' legitimacy perceptions. If increased authority had affected perceptions of procedural and performance quality, then we could have observed a corresponding effect on citizens' legitimacy perceptions. Our results hold when measuring perceived legitimacy in different ways, and when reducing the sample to participants who answered comprehension questions correctly and thus clearly understood the treatments.

Our results have interesting implications for the climate governance framework and global governance institutions more broadly. They suggest that there is greater leeway than commonly assumed for shifting authority to global governance institutions without risk of domestic public backlash. They also suggest that legitimation efforts by international organization are necessary particularly with respect to citizens who are less familiar with and less interested in international politics.

In the next section, we elaborate on the authority-legitimacy link. We then describe the study design, followed by the empirical findings, and a discussion and conclusion section.

\section{The Authority-Legitimacy Link from a Public Opinion Perspective}

Many authors note that global governance institutions have been acquiring more and more authority over the past decades (Blake and Payton 2015, Hooghe and Marks 2015; Zürn 2015). This means that authority originally located within countries is being pooled internationally and delegated 
by states to such institutions (Hooghe and Marks 2015). Delegation, in this context, refers to states transferring agenda setting, decision-making, and implementation authority to global governance institutions, while pooling refers to changes in voting rules, such as shifting from consensus to majority voting in global governance institutions or reducing domestic implementation hurdles for international agreements (Hooghe and Marks 2015).

Increases in the authority of global governance institutions have gone hand in hand with mounting concerns from observers and academics over the legitimacy of these institutions (Koppell 2008; Li 2003; Wolf 2007). We define legitimacy as the belief by constituents and observers that the authority of a global governance institution is being appropriately exercised and thus meets their procedural and performance standards (Gibson and Caldeira 1995; Bodansky 1999; Bernstein 2011; Bernauer and Gampfer 2013; Voeten 2013; Dellmuth and Tallberg 2015). One frequent criticism of the increasing authority of global governance institutions concerns procedural shortcomings, namely, the "democratic deficit" in terms of limited or deficient participation, accountability, and representation (Grant and Keohane 2005; Hobolt 2012; Keohane and Nye 2003; Anderson and Slaughter 2005; Wilkinson and Hughes 2002). Other observers have criticized the performance of such institutions, for example, their failure to deliver effective solutions or distributional fairness. What remains unclear is to what extent citizens' legitimacy perceptions are affected by these shifts of authority.

Existing work on the link between authority and citizens' legitimacy perceptions uses observational data, often in aggregated form, which makes it difficult to assess whether authority affects legitimacy perceptions or citizens simply rely on elite cues (see Gabel and Scheve 2007; Dellmuth and Tallber this volume) or other heuristics to inform their legitimacy perceptions. Examples include the European Union (see Hooghe and Marks 2005; McLaren 2002), the World Trade Organization (Esty 2002), and the World Economic Forum (Della Porta et al. 2006; Levi and 
Murphy 2006). For example, Hooghe and Marks (2009) note a shift in public attitudes from “permissive consensus” to a “constraining dissensus” towards the European Union as authority shifted from market integration to an increasingly complex system of governance dealing with a plethora of policy-areas. This is argued to have caused a loss of public trust and increased dissatisfaction with the European Union (Eichenberg and Dalton 2007; and Blondel et al. 1998). These results serve as a starting point. However, their empirical limitations preclude any definitive conclusions on how citizens link authority and legitimacy if at all.

Dellmuth and Tallberg (this volume) among others argue that citizens lack the necessary time and capacity to understand the features and functions of global governance institutions, which limits their ability to draw conclusions regarding legitimacy. ${ }^{1}$ Many scholars in fact argue that citizens are rationally ignorant (Downs 1984) or even irrational with respect to politics (Caplan 2001; Lupia 2015). They are apathetic to spending time and effort to acquire information about policy issues or participate actively in political decisions (Downs 1984). This may be particularly true if citizens perceive elites as acting in their best interest, or if policy issues are complex and hard to understand (Hibbing and Theiss-Morse 2002), which may be the case for various global governance issues (Gallup International 2005). Therefore, it is widely presumed that "ordinary” citizens form their opinions and legitimacy beliefs based on cues or frames they receive from elites and the media (Dellmuth and Tallberg 2015; Schlipphak 2015; Johnson 2011; Chong and Druckman 2007; Dellmuth and Tallberg this volume; Schneider, Schmidtke and Nullmeier this volume; Tallberg and Zürn this volume). Based on this reasoning, we should not expect any direct effect of authority on citizens’ legitimacy perceptions.

However, the absence of a direct effect of authority on legitimacy perceptions (which remains to be demonstrated empirically) may be difficult to interpret. Is it due to citizens’ ignorance

\footnotetext{
${ }^{1}$ See Dellmuth and Tallberg this volume; Schmidtke this volume; and Tallberg and Zürn this volume.
} 
with respect to global governance or their incapacity to evaluate the authority of these institutions? Or could it be that individuals are capable of assessing the authority-legitimacy link, as circumstantial evidence suggests (see Hooghe and Marks 2005), but that shifts of authority do in fact not affect their legitimacy perceptions? Our analysis will shed more light on this issue. If the former is true, that citizens truly cannot grasp global governance, then we should also expect insignificant relationships between: (1) perceived authority and actual authority, (2) perceived legitimacy and perceptions of procedural and performance quality, and (3) perceived authority and perceived legitimacy. That reason is that if citizens are ignorant or incapable of understanding global governance institutions, then they will randomly judge, guess, or apply a heuristic such as their trust or confidence in national institutions to form perceptions of global governance institutions' procedural or performance quality as well as their authority. This will result in insignificant relationships. If the latter is true, meaning that citizens understand global governance, but shifts of authority still do not affect their legitimacy perceptions, then we should expect to find a significant and positive correlation between: (1) citizens’ perceived authority and the actual authority of a global governance institution, (2) a significant and positive correlation between citizens' legitimacy perceptions and their perceptions of procedural and performance quality, and (3) a significant correlation between perceived authority and perceived legitimacy. This leads to the following main hypothesis:

H1: Increases in authority of global governance institutions are unlikely to have a direct overall effect on citizens’ legitimacy perceptions.

Though, as hypothesized, the overall direct effect is likely to be insignificant, particular types of citizens are perhaps more likely to link authority and legitimacy. Notably, even if the bulk of citizens were incapable of independently assessing the authority-legitimacy link, the need for cues by elites to that end is likely to decline as education, political astuteness, and interest of citizen increase (Inglehart 1970; Shively 1979). Access to information is likely to produce a qualitative change in the 
political sophistication of citizenry (Inglehart 1977). Moreover, global governance institutions are increasingly engaged in campaigns aimed at promoting themselves to the general public and other stakeholders (Rauh and Zürn this volume; Tallberg and Zürn this volume). Because of this increased access to information and cognitive mobilization, more citizens can grasp the complexities of global governance and formulate their own legitimacy perceptions. In other words, citizens are likely to possess, to varying degrees, the skills and resources necessary to become politically engaged without dependence on external cues (Dalton 1984). Those who are highly mobilized are those who possess both the skills and motivation to grapple with the complexities of global governance on their own, and as a result, be able to evaluate the authority of a global governance institution. Thus, we expect that:

H2: Increases in authority of global governance institutions are more likely to affect the legitimacy perceptions of those who are cognitively mobilized.

Similarly, we expect that those who are highly concerned and interested in the specific issue a global governance institution is dealing with will be more motivated to grapple with these complexities and understand the intricacies of global governance independently. As noted above, accessing information has become much easier in recent decades; thus we expect that such individuals will have the interest and desire to understand the authority and structure of the respective global governance institution. Therefore, we expect that:

H3: Increases in authority of global governance institutions are more likely to affect the legitimacy perceptions of those who are highly interested or concerned about the issue the respective global governance institution is dealing with (in our case, this is climate change).

Whether the link between authority and legitimacy is a tradeoff or mutually reinforcing amongst cognitively mobilized or highly concerned individuals remains open in the context of climate governance. We cannot see a compelling theoretical reason to expect a uniformly negative or 
positive effect and suspect that the direction of the effect depends on the specific policy context. In climate policy, many observers have diagnosed rather low legitimacy, whereas pooling and delegation have been relatively weak for the time being (Vihma 2011). Many authors attribute this presumed legitimacy loss to poor performance of the climate governance framework in delivering effective solutions to the problem, whereas others have also criticized procedural aspects of the system (Falk and Strauss 2001; Held and Koenig-Archibugi 2005; Scholte 2007; Dimitrov 2010; Lidskog and Elander 2010; Doherty and Wolak 2012; Bernauer and Gampfer 2013; Hickmann 2016). From a policy perspective, it will be interesting to find out whether increasing the authority of the climate governance framework is likely to affect perceived legitimacy positively or negatively, or have no effect.

\section{Study Design}

We use an experimental design to investigate the causal effect of increased authority of global governance institutions, specifically, the climate governance framework, on citizens' legitimacy perceptions. Though in reality the authority of the global climate governance framework is fixed, an experimental approach enables us to study the implications of institutional features reflecting varying degrees of authority in a systematic way. The remainder of this section starts with a brief discussion of the climate governance framework and its relevance. We then describe the experimental treatments (i.e., levels of authority), the response variable (i.e., perceived legitimacy), the survey design, and the statistical approach. 


\subsection{Global Climate Governance}

We focus on the climate governance framework for two reasons. First, climate change is a global problem. Greenhouse gas (GHG) emissions from everywhere on Earth accumulate in the global atmosphere and affect everyone, albeit to different degrees. Solving this problem thus requires action worldwide in terms of mitigation (i.e., reducing GHG emissions) and adaptation to climatic changes. The nature of this challenge raises interesting questions about the authority-legitimacy link in global governance, in the sense that pooling of authority could potentially deliver the most effective solution but could result in a loss of legitimacy given prior examples, such as the EU (Hooghe and Marks 2005) or WTO (Esty 2001).

Second, effective climate change governance requires costly behavioral changes down to the level of individual citizens (Semenza et al. 2008). As noted by observers to the negotiations of the 2015 Paris Agreement, "Climate change policy is almost entirely about domestic policy, and domestic policy is mostly driven by domestic politics” (Council of Foreign Relations 2015). To the extent that the authority of the climate governance framework increases and policies emanating from this framework reach ever deeper into the domains of local and national political authority, perceived legitimacy is likely to play an important role (Holcombe 2006; Bernstein 2011). Thus, perceived legitimacy matters greatly in this policy area, particularly in democratic countries.

The climate governance framework, which is organized primarily through the UNFCCC, seeks to overcome the collective action problem in global climate change mitigation (Bernauer 2013). Its purpose is to help curb GHG emissions in order to avoid major negative socio-economic and ecological consequences that would result if temperatures rose by more than 1.5 to 2 degrees Celsius.

In 1997, the Kyoto Protocol set modest legally binding GHG emissions reduction targets for industrialized countries. Negotiations on a follow-up Protocol for the time period after the Kyoto Protocol, which ended in 2012, failed and negotiations retracted into a governance effort based on 
self-selected, nonbinding emission reduction targets under the 2015 Paris Agreement. The latter approach can be characterized as a pledge-and-review system or internationally coordinated unilateralism. Current estimates hold that global warming will exceed 2 degrees even if all existing pledges were fulfilled. ${ }^{2}$ This means that more ambitious policies are required to prevent dangerous levels of global warming.

Policymaking in this area has been accompanied by contentious debates over how to best organize the governance effort. The poles of the debate emphasize authoritative target setting and decision-making at the global level on the one side and decentralized bottom-up efforts on the other. In fact, some scholars have questioned whether the existing climate governance framework is even necessary to solve the climate change problem, given the variety of decentralized sub- and non-state governance frameworks and actors (Keohane and Victor 2011; Bulkeley and Newell 2015). However, as Hickmann (2016) notes, even though national governments and international institutions are not the only relevant actors in the global response to climate change, the principles, norms, and rules established in the UNFCCC climate governance framework are important for setting the agenda in climate policy and informing the initiatives launched at transnational, subnational and non-governmental levels. Moreover, even if authority is shifting away from the global climate governance framework back towards national and local levels, observers point out that the collective action problem must ultimately be resolved via globally agreed on binding targets (Bernauer 2013; Rogelj, Meinhausen, and Knutti. 2012). In light of this, we are interested in what a renewed shift of authority towards the global level would entail for legitimacy, and how much authority could be shifted without a loss of legitimacy.

Empirically, we focus on public opinion in Germany and the United States. Germany, the largest economy in Europe, advocates ambitious climate policies, whereas the US, the world's largest GHG emitter in historical terms, did not join the 1997 Kyoto Protocol and has no coherent federal climate

2 http://climateactiontracker.org/ 
policy in place. Moreover, for the last half century, the German public has been exposed to supranational governance in the EU, while the US public has not. We are interested in whether our empirical findings are similar or different across these two very different political contexts.

In the survey, we do not explicitly refer to the UNFCCC. Instead, we use the term "Global Climate Conference”. Using a fictional institution resembling the real governance framework allows us to vary levels of authority and avoid priming effects inherent in associating the negotiations with the UN, which on its own may evoke polarized reactions. In the survey, participants first read an introduction to climate change followed by an introduction to a Global Climate Conference.

\section{[Page 1]}

We burn large amounts of coal, oil and gas when producing energy and in transportation. When we burn these fossil fuels, we emit carbon dioxide $\left(\mathrm{CO}_{2}\right)$ into the atmosphere. Growing amounts of carbon dioxide $\left(\mathrm{CO}_{2}\right)$ in the atmosphere cause the global temperature to rise. This is commonly referred to as climate change or global warming. To prevent further temperature increases, governments from around the world are meeting to design a worldwide strategy.

\section{[Page 2]}

Specifically, governments meet annually at the Global Climate Conference, which includes 190 countries along with [the United States/Germany]. Their aim is to negotiate an international agreement to reduce carbon dioxide $\left(\mathrm{CO}_{2}\right)$ emissions worldwide. This meeting is also known as the Conference of the Parties to the Framework Convention on Climate Change.

Negotiations at the Global Climate Conference focus on two issues:

- How much should worldwide carbon dioxide $\left(\mathrm{CO}_{2}\right)$ emissions be reduced?

- How much should each country reduce its carbon dioxide $\left(\mathrm{CO}_{2}\right)$ emissions to achieve the worldwide goal?

\subsection{Treatments}

The key explanatory variable in our experiment is authority. We conceptualize authority on two dimensions: voting procedure at the international bargaining stage (consensus or majoritarian voting) and domestic ratification requirements (automatic implementation or implementation only after approval by the national legislature). These two dimensions allow us to generate experimentally 
manipulated variation of authority in global governance using the typology by Hooghe and Marks (2015) (see Figure 1). Hooghe and Marks (2015) define two facets of authority: pooling and delegation. We concentrate on pooling, which concerns the rules under which states make decisions and the procedure through which those decisions are implemented at the domestic level. According to this conceptualization, the authority of the climate governance framework is fairly limited as it currently stands. Consensus voting and implementation only after approval by the respective country's national legislature requires the least pooling of authority. Majoritarian voting and automatic implementation lies at the other end of the spectrum and involves a high degree of pooling. In between these two levels of delegation fall the other two conditions: ConsensusAutomatic and Majority-Legislature (see Figure 1). In our experiment, the status quo (i.e., Consensus-Legislature) serves as the baseline. Table 1 shows the wording of the four treatment conditions. Survey participants were randomly assigned to one of the four combinations after having read the introductory text above.

\section{INSERT FIGURE 1}

\section{INSERT TABLE 1}

We included three comprehension questions and a manipulation check. The comprehension questions capture whether survey participants (1) understood the purpose of the Global Climate Conference as well as (2) the voting and (3) domestic implementation procedure to which they were assigned. In the empirical analysis, we assess the robustness of our findings by excluding participants who incorrectly responded to one or more of the comprehension questions on their second attempt.

The manipulation check helps us understand whether the treatment conditions were effective in manipulating participants’ perceptions of authority. By implication, it also provides information on whether participants understood the consequences of a particular voting rule and implementation arrangement. We asked participants: Do you think this process of deciding whether and how much 
[the United States/Germany] must reduce its carbon dioxide emissions gives [the United States/Germany] too little or too much control over this policy? (No control, too little control, sufficient control, too much control).

The results indicate that participants perceived the pooling of authority as intended. In terms of domestic ratification requirements, participants from both countries perceived ratification by the legislature as providing significantly more control over climate policy than automatic implementation. In regards to the international voting procedure, only US participants perceived the consensus rule as providing significantly more control by the American government than majority voting. By and large, these results confirm that participants perceived the experimentally induced variation in authority as intended and understood the implications of increasing authority. Figure 2 shows the probability of a participant selecting no control in response to the manipulation check. The probability of doing so after exposure to the Consensus-Legislature treatment is significantly lower than the Majority-Automatic treatment for the US and German samples. The Consensus-Automatic treatment falls in-between the extremes, and the effect of the Majority-Legislature treatment is not significantly different from the Consensus-Legislature treatment. The probability plots for the response categories too little control, sufficient control, and too much control can be found in SI-1 (Supplementary Information Section 1).

INSERT FIGURE 2

\subsection{Dependent Variable}

Since no widely accepted survey items exist to measure legitimacy perceptions of global governance institutions, we build on the conceptual and theoretical literature on legitimacy to construct three different measures. This approach serves to assess the internal validity and robustness of our results. 
Tallberg and Zürn (this volume) define legitimacy as the belief that authority is being appropriately exercised, which in turn, causes a continued deference to authority. We use two survey items to gauge these two facets of legitimacy in this definition, appropriateness and deference. ${ }^{3} \mathrm{We}$ asked survey participants whether they agree, somewhat agree, somewhat disagree, or disagree with I think the Global Climate Conference serves an important role in society (APPROPRIATE) and The Global Climate Conference should continue to make decisions in the future (DEFERENCE). If participants agree or somewhat agree with these statements, we interpret them as the Global Climate Conference being perceived as legitimate, while disagree or somewhat disagree means that participants perceive the Global Climate Conference as illegitimate. ${ }^{4}$ It is important to emphasize that this is distinct from authority, which is the legal right to make decisions in an area. Legitimacy implies that an individual believes that an institution should continue to make decisions.

These two measures, in isolation, capture a narrow conceptualization of legitimacy. A broader conceptualization of legitimacy would be the perception that the actions of an institution are appropriate within some socially constructed system of norms, values, and beliefs (Suchman 1995, Tallberg and Zürn this volume). APPROPRIATE and DEFERENCE fail to capture an individual's social affinity with an institution. This interpretation is referred to as "substance-grounded" legitimacy, that is, legitimacy beliefs that result from individuals perceiving the goals or purpose of an institution as inherently desirable (Scott 2013). To measure this broader conceptualization, we added three more items. We asked survey participants whether they agree, somewhat agree, somewhat disagree, or disagree with the following three statements, in addition to DEFERENCE and APPROPRIATE:

\footnotetext{
${ }^{3}$ Other studies measure related concepts such as confidence or trust as proxies for legitimacy. We argue that these are necessary conditions of legitimacy but not sufficient. Measuring only these concepts can present a misleading picture. For example, it is possible to be confident in an institution to perform its duties, e.g., Stalin's Communist Regime, but not view its authority as being appropriately exercised, i.e., legitimate.

${ }^{4}$ We opted for an ordinal scale for these two questions instead of a binary (Agree/Disagree) based on participant feedback from a pilot survey at the end of 2014. In the 2014 pilot survey, we randomized binary and ordinal response categories between participants. Several participants who received the binary response option commented that they were unable to express nuanced opinions, while we received no comments from those who received the ordinal scale. This is why we decided to use the ordinal response category in the present survey.
} 
- The principles of the Global Climate Conference match my own.

- I sympathize with the goals of the Global Climate Conference.

- I believe the Global Climate Conference is necessary.

We randomized the order of the five questions between participants. For robustness checks, we aggregated these three additional items together with APPROPRIATE and DEFERENCE using item response theory (for details see SI-2). This aggregate measure of all five items is referred to as 5ITEM in the robustness checks.

It is worth noting that these dependent variable items focus on legitimacy perceptions with respect to how climate policy-making should unfold, rather than on climate policy preferences per set. That is, while climate change deniers are likely to find global climate policy-making illegitimate almost by definition, those supporting at least some steps towards mitigating GHG emissions are likely to differ strongly in how policies to that end should be established and implemented.

\subsection{Survey Design}

The survey was designed by the authors and fielded by YouGov to its online panels in Germany and the US between the $12^{\text {th }}$ and $22^{\text {nd }}$ February 2016. The respondents were matched to a specific sampling frame in order to approximate a sample that is representative of the German and US populations ( $\mathrm{N=1600} \mathrm{each).} \mathrm{For} \mathrm{example,} \mathrm{in} \mathrm{Germany,} \mathrm{YouGov} \mathrm{interviewed} 1718$ respondents and then matched them by gender, age, and education, to a sampling frame, reducing the number to 1600 in the final dataset (for specifics see SI-3).

The survey started with a brief description of climate change and the purpose of the climate governance framework referred to as the Global Climate Conference, followed by a description of the voting procedure as well as domestic implementation requirements. After each of these descriptions, participants received a comprehension check item. If the answer was incorrect, they 
were sent back to the prior description/treatment. After their second attempt, participants could proceed regardless of whether the response was correct. Table 2 summarizes, by treatment group, the proportion of participants who answered the three comprehension questions correctly by their second attempt. In both countries, 3 percent of the sample failed to correctly identify the purpose of the climate governance framework (first comprehension question) twice, 9 percent misunderstood the voting rule (second comprehension question) twice, and 13 percent misunderstood the ratification requirements twice (third comprehension question). Overall, 20.6 percent and 15.4 percent of American and German respondents, respectively, failed to answer one or more of the questions correctly by their second try. In the robustness checks, we run analyses on the reduced sample, which only includes participants who answered all three comprehension questions correctly by their second attempt.

\section{INSERT TABLE 2}

Around 15 percent of the participants, in both countries, failed to answer all three comprehension check questions correctly after both attempts across all treatment groups. However, in the two treatments involving the automatic implementation of the climate agreement in the US, nearly 25 percent failed to answer correctly by the second try (see Table 2). One possible reason is that this treatment seemed too unrealistic to participants. We used data from the following survey item to assess this possibility: Now that you have read the description at the beginning of the survey, how well do you understand what the Global Climate Conference is and how it works? (Very well, well, to some extent, a bit, not at all). We tested for significant differences in the distribution of responses to this item across treatments in the German and US samples. This would indicate whether the automatic implementation treatment was regarded as unrealistic or overly confusing from the viewpoint of US participants. However, we did not observe significant differences in the distribution of responses to this item across treatments in either sample. 
After the treatments and comprehension questions, we summarized the treatments in a flow chart to ensure participants understood the voting rule of the climate governance framework and the domestic implementation procedure. Then we measured participants’ perceived legitimacy of the climate governance framework (i.e., dependent variable). ${ }^{5}$

Participants then received four blocks of questions measuring their climate change concern, knowledge on climate change, self-reported interest in international politics, and understanding of international politics. We randomized the order of these blocks of questions as well as the questions within each block between participants. The survey ended with a set of demographic questions (the wording of all items is shown in SI-7).

\subsection{Statistical Approach}

For the two main dependent variables, APPROPRIATE and DEFERENCE, we used ordinal logistic regressions and estimate the predicted probabilities of agreeing and disagreeing with APPROPRIATE and DEFERENCE after each treatment. We calculate the differences between the predicted probabilities of the status quo (Consensus-Legislature) and each of the other treatments (Consensus-Automatic, Majority-Legislature, Majority-Automatic), for example, $\operatorname{Pr}$ (Agree|Consensus-Legislature) - Pr(Agree|Majority-Legislature). We bootstrapped to calculate the standard errors of these differences by resampling data with replacement $(\mathrm{N}=3200)$ over 1000 iterations. ${ }^{67}$

\footnotetext{
${ }^{5}$ We randomized the order of the five legitimacy items and response scales between participants, which were followed by the manipulation check.

${ }^{6}$ Bootstrapping is a way of estimating statistical parameters from the sample by resampling with replacement. Like other non-parametric approaches, bootstrapping does not make any assumptions about the distribution of the sample. The main assumption behind bootstrapping is that the sample distribution is a reasonably good approximation of the population distribution. This is a reasonable assumption in our case because YouGov provided weighted samples of German and American populations. It is for this reason that we chose bootstrapping over other simulation methods that generate new data as a means of estimating these standard errors. In addition, other simulation techniques would have required assumptions about the distribution of the data, which we prefer to avoid.
} 
To estimate the robustness of results using the 5-ITEM measure, which is continuous, we use an OLS regression to calculate the mean predicted values on the 5-ITEM scale for each treatment. We calculated the difference in means for each treatment compared to the status quo (i.e., Consensus-Legislature). We then bootstrap to calculate the standard errors in the same manner as above.

\section{Results}

We start by reporting descriptive statistics for the dependent variable followed by the main results. We then engage in a series of robustness checks focusing on the additional 5-ITEM measure and the reduced sample that excludes respondents who did not correctly answer all comprehension questions by their second attempt.

\subsection{Legitimacy Perceptions}

Figures 3 and 4 show the distributions of responses on the two dependent variables, APPROPRIATE and DEFERENCE, respectively, irrespective of treatment. The distributions of the entire sample (i.e., including all treatments) shown in Figures 3 and 4 are left-skewed, meaning there could be ceiling effects. Figure 5 shows the distribution of scores on the combined 5-ITEM measure for the entire sample that we use for robustness checks. In Figure 5, there is a peak in the German sample at around 0 , which indicates an ambivalent perception of legitimacy, and 1 , which indicates a high level of perceived legitimacy. The shape is slightly different for the US sample, where there is a peak around -2, indicating a low level of perceived legitimacy, 0 , and 1.

\footnotetext{
${ }^{7}$ There is some debate over how much iteration is necessary. We started with 10,000 and shifted to 1000 after initial results were similar.
} 


\subsection{Effects of Authority on Legitimacy Perceptions}

For APPROPRIATE and DEFERENCE, we observe no significant differences in the probability of agreeing or disagreeing between the status quo (Consensus-Legislature) and the other three treatment groups for the German and US samples (including all participants). Thus, there are no significant differences in legitimacy perceptions across treatments. Figures 6 and 7 show the histogram plots of the differences in predicted probabilities of agreeing with APPROPRIATE between the Majority-Automatic and Consensus-Legislature treatments for the full samples. QQ plots of 1000 iterations show that the distribution is close to normal (see Figures SI-4.1 and 4.2 in SI4). Therefore, we calculate the 95 percent confidence intervals using the normal distribution. The difference in predicted probabilities of agreeing with APPROPRIATE, i.e., perceiving the global climate governance framework as legitimate, in the US and Germany between ConsensusLegislature (baseline condition) and Majority-Automatic treatments is $(-0.13,0.05)$ and $(-0.03,0.15)$, respectively, with 95 percent confidence. Both confidence intervals include zero; therefore, we cannot reject the null hypothesis, that the authority of the climate governance framework does not affect citizens' legitimacy perceptions. The confidence intervals and significance for other treatments can be found in SI-4.

\section{INSERT FIGURE 6 and 7}

The results thus far show that, contrary to a widespread presumption, increasing the authority of the climate governance framework does not per se undermine its perceived legitimacy. The manipulation and comprehension questions show that participants understand the implications of different decision and implementation rules. However, we cannot find empirical evidence for a 
tradeoff between authority and legitimacy, in the sense of one coming at the expense of the other, or for an amplifying effect, in the sense of one increasing the other.

It is possible that subsets of participants perceive authority differently in the same treatment, which could then lead to effects cancelling each other out and causing insignificant results. For example, participants who consider that their government has no control over climate policy under the Consensus-Legislature condition might cancel out the effect of those who perceive their government as having too much control or sufficient control under Consensus-Legislature treatment. Table 3 shows participants' perceptions of authority in each treatment, in terms of the total number of participants from each country and the percentage. For example, 13 participants or 3 percent of the German sample believed Germany had no control in the Consensus-Legislature treatment. There are only a small number of individuals who failed to perceive treatments as intended. For example, 3 percent and 8 percent of Germans and US respondents receiving the Majority-Automatic treatment, respectively, perceived the Majority-Automatic treatment as leaving their respective countries too much control over climate policy.

\section{INSERT TABLE 3}

Due to the relatively small numbers in a few of the sub-groups, we were unable to use bootstrapping. We ran ordinal logistic regressions on APPROPRIATE and DEFERENCE, interacting our treatments with the manipulation check item, i.e., perceived authority. The interaction effect between perceived authority and treatments is insignificant (see SI-5 (a) for Table SI-5.1 of results). Therefore, we can rule out the concern that effects are cancelling each other out.

It is important to note that in the analysis above we find that citizens' perceptions of authority are significantly correlated with legitimacy (see Table SI-5.1). In the German sample, those who perceive the climate governance framework as giving Germany no control or too much control over climate policy tend to perceive this framework as significantly less legitimate, regardless of 
treatment, than those who perceive the framework as providing too little control or sufficient control. In the US sample, those who perceive the climate governance framework as leaving the US with no control over climate policy perceive the framework as significantly less legitimate than those who perceive it as providing too little control, sufficient control, or too much. Importantly, neither result is a linear relationship. Rather, we find a more nuanced relationship between participants' perceptions of authority and legitimacy. In the German sample, there seems to be an inverted-U shaped relationship between the perception of authority and legitimacy, while in the US sample, it seems that the climate governance framework is regarded as legitimate as long as the US retains a minimum amount of control. Perhaps this difference is due to Germany being embedded in a supranational institution, the European Union, for around half a century, whereas the US never joined any such institution. That is, Germans might recognize the pitfalls of having "too much control” over policy and benefits of relinquishing some control to a supranational institution, while US citizens lack such experience. Even though the relationship between perceived legitimacy and perceived authority is counter to expectations, it does indicate the citizens understand global governance and make these assessments.

One other explanation for the null result could be that the effects of participants with different political ideologies cancel each other out. Norris (2000), for instance, finds that left-leaning ideology is associated with cosmopolitanism. Thus, the opposing effects for liberals and conservatives could be masking treatment effects on perceived legitimacy. To clarify this issue, we carried out ordinal logistic regressions on APPROPRIATENESS and DEFERENCE for the full sample, and included interaction effects between political ideology and authority of the climate governance framework (see SI-5 (b) for details on measurement, Tables SI-5.2 and SI-5.3 for results). The results show no significant interaction effects. Therefore, we can rule out this possibility. However, we do find similar results to Norris (2000) for the US sample. The more right-leaning a study participant is the less legitimate she/he finds the climate governance framework. 
As discussed in the theory section, cognitive mobilization and climate concern might also moderate the effect of authority on legitimacy. We address each of these possibilities in turn.

We measured cognitive mobilization by asking participants: How interested are you in international politics? (Extremely interested, very interested, somewhat interested, not at all interested). We then used a similar approach as above (i.e., bootstrapping on differences in predicted probabilities) amongst those who are extremely interested and not at all interested. The results are inconsistent. For individuals who are extremely interested and in the US sample, there is a significant difference in the probability of agreeing with DEFERENCE between the Consensus-Legislature and Majority-Automatic treatments $(-0.70,-0.13$, with 95 percent confidence). Similarly, there is a significant difference in the probability of disagreeing with DEFERENCE $(0.002,0.33$, with 95 percent confidence). This means that US participants who are more cognitively mobilized perceive pooling more authority in the climate governance framework as more legitimate. However, there is no significant difference in the probability of agreeing with APPROPRIATE between the Consensus-Legislature and Majority-Automatic conditions for more cognitively mobilized individuals in the US sample. For the other treatments, we find insignificant differences in perceived legitimacy between the baseline (Consensus-Legislature) and other treatment conditions for either measure of legitimacy amongst cognitive mobilized individuals in the full samples from both countries (for confidence intervals see SI-4 (a)).

Climate change concern is measured using item wordings from the PEW's Index of Climate Concern (Pew Research Center 2015). This measure is an additive index comprised of the following items:

- In your view, is global climate change a very serious problem, somewhat serious, not too serious or not a problem? (4-very serious problem, 3-somewhat serious, 2-not too, 1-serious or not a problem). 
- Do you think global climate change is harming people around the world now, will harm people in the next few years, will not harm people for many years or will never harm people? (4-Harming people around the world now, 3-Will harm people in the next few years, 2-Will not harm people for many years, 1-Will never harm people).

- How concerned are you, if at all, that global climate change will harm you personally at some point in your lifetime? Are you very concerned, somewhat concerned, not too concerned or not at all concerned? (4-very concerned, 3-somewhat concerned, 2-not too concerned, 1- not at all concerned).

Scores range from 3 (no concern) to 12 (high concern).

We bootstrapped differences in predicted probabilities of agreeing and disagreeing with our dependent variables for highly concerned individuals (score of 12) and those with low levels of climate change concern (score of 3). For the full samples, we find insignificant differences in perceived legitimacy between the baseline (Consensus-Legislature) and the other treatment conditions for either measure of perceived legitimacy amongst those who are very concerned and not at all concerned about climate change (see SI - 4(c) Tables 4.6 - 4.9). In addition, we conducted ordinal regressions with APPROPRIATE and DEFERENCE as the dependent variables, for the full samples and interacting climate change concern with levels of authority (i.e. treatment groups). These relationships are statistically insignificant. However, climate change concern is a significant predictor of perceived legitimacy: as concern increases so does the perceived legitimacy of the climate governance framework independent of treatments. This again suggests that prior attitudes towards climate change risks and policy are more important drivers of perceived legitimacy than authority levels. We will return to this issue further below. In the supplementary information (SI-8) we discuss a series of robustness checks, all of which end up supporting the main results presented here. 


\subsection{Factoring In Procedural and Performance Assessment}

Should we interpret the lack of an effect of authority on legitimacy as evidence that citizens cannot understand how political decisions are made when it comes to climate governance? We believe that this conclusion would be premature and requires further analysis. As a first step, we examine treatment effects on individuals' perceptions of procedure and performance in global climate governance, and whether these perceptions are associated with perceived legitimacy. The “citizens are ignorant” claim, in order to be empirically supported, would require demonstration of an insignificant relationship between: (1) perceived authority and actual authority, (2) perceived legitimacy and perceptions of procedural and performance quality, as well as (3) perceived authority and perceived legitimacy.

For this analysis, we use survey items gauging perceptions of the climate governance framework's procedure and performance (see SI-7). As noted in Section 2.1, critics of global governance commonly point to a democratic deficit in terms of deficient participation, accountability, and representation (Grant and Keohane 2005; Hobolt 2012; Norris 2000; Slaughter 2005; Wilkinson and Hughes 2002). We measured perceptions of the democratic quality of the climate governance framework using: The Global Climate Conference is undemocratic (agree, somewhat agree, somewhat disagree, disagree). Another procedural concern in global governance is infringement on national sovereignty. We thus asked participants: No country should be pressured into reducing its carbon dioxide $\left(\mathrm{CO}_{2}\right)$ emissions if it does not want to (agree, somewhat agree, somewhat disagree, disagree). Lastly, to measure individuals’ perceptions of the climate governance framework's performance, we asked: It does not matter how negotiations are conducted and what the voting rules are, the Global Climate Conference is too ineffective to stop climate change (agree, somewhat agree, somewhat disagree, disagree). 
We carried out ordinal logistic regressions using the three items as dependent variables, with the treatments serving as the main explanatory variables. We find an insignificant relationship between authority levels and participants’ perceptions of procedure as well as performance of global climate governance. The results are the same for the full and the reduced samples (for details, see SI$6)$.

We continued by estimating ordinal logistic regressions with these three items as explanatory variables and legitimacy measures as dependent variables (APPROPRIATE, DEFERENCE, 5-ITEM measure). Table 4 shows the results for the full samples. The results remain the same for the reduced samples from Germany and the US. It turns out that individuals' perceptions of the procedure and performance of the global climate governance framework are significantly associated with perceived legitimacy. People who perceive the global climate governance framework as more "democratic" and "effective" perceive it as more legitimate. Lastly, people who believe that the climate governance framework will pressure their country perceive it as less legitimate. In other words, our results indicate that citizens relate their perceptions of process and performance quality with their evaluation of legitimacy. However, the level of authority of the global climate governance framework does not seem to significantly affect these perceptions.

\section{INSERT TABLE 4}

We also asked survey participants follow-up questions to better understand why they view the Global Climate Conference as democratic or undemocratic. In the full sample, 872 participants selected agree or somewhat agree to the statement, The Global Climate Conference is undemocratic, while 1591 participants answered disagree or somewhat disagree. 737 respondents skipped this question. If participants answered agree or somewhat agree, then they were asked: The Global Climate Conference is undemocratic because ... while those who answered disagree or somewhat disagree were asked The Global Climate Conference is democratic because... We then showed 
participants a list of reasons and asked them to click all that applied if any. The options were identical for the two groups. Table 5 and 6 show the proportions of participants who selected specific reasons. The most common reasons for those who perceived the Global Climate Conference as undemocratic included countries in negotiations are undemocratic followed by negotiations are dominated by business interests. For participants who believed the Global Climate Conference is democratic, 65 percent selected Voting rule is democratic followed by Implementation procedure is democratic.

INSERT TABLE 5 AND 6

No one reason explains why the Global Climate Conference was perceived as undemocratic or democratic. What we can conclude from this is that individuals have different procedural and performance standards; therefore, the same attributes can illicit different reactions. Searching for universally legitimate criteria, such as a "perfect" voting rule would thus be bound to fail. Pooling greater authority is neither a blessing nor a curse. It seems to depend on the individual whether this is perceived as legitimate or illegitimate. In summary, while perceptions of procedural and performance quality are significantly correlated with legitimacy, the criteria that inform these perceptions of procedural and performance quality vary extensively between individuals.

\section{Discussion}

Contemporary campaigns by populist political movements on the left and right, as well as specific instances of political backlash, such as the widespread opposition to TTIP, the EU, the WTO, and other international institutions suggest that shifting political authority from the domestic to the international level could come at the expense of legitimacy. In this paper, we examined whether changes in authority affect the legitimacy perceptions of citizens in the context of climate 
governance, using population-based survey experiments fielded in Germany and the US.

The results cast doubt on a link between the authority of the global climate governance framework and citizens' legitimacy perceptions. Nuanced shifts in authority, such as changes towards majority decision making at the international level and automatic implementation of international decisions domestically, do not significantly affect citizens’ legitimacy perceptions. It is important to emphasize that this result is not due to citizens' lack of understanding of the implications of changes in authority. In fact, citizens do understand that their government loses control over climate policy as international pooling of authority increases. Moreover, legitimacy perceptions are significantly correlated with citizens' assessments of procedural and performance quality. But it appears that shifts in authority as such do not affect these perceptions, which in turn explains the insignificant effect of variation in international authority on perceived legitimacy. The results suggest, however, that the authority of the climate governance framework affects legitimacy perceptions amongst cognitively mobilized individuals, and that this relationship is mutually reinforcing. As the authority of the climate governance framework increases, so does its legitimacy, showing that increasing authority does not necessarily come at the expense of legitimacy.

To put our results into the broader context of legitimacy of global governance institutions, we find very limited support for a direct effect of changes in authority on legitimacy, but identify a direct effect of perceptions of procedural quality and performance. This implies that as long as shifts of authority do not negatively affect citizens' perceptions of procedural quality and performance there should not be a corresponding effect on legitimacy. Overall, these findings suggest that there is considerable room for increasing the authority of global governance institutions, provided this can be done in ways that ascertain high procedural and output performance quality.

Future research could vary the policy area as part of experimental treatment conditions. It would be interesting to discern differences in effects increasing authority levels of global governance 
in areas such as immigration, taxation, trade, banking regulation, or security might have on perceived legitimacy by specific types of citizens. Conventional wisdom, at least from the perspective of debates on the EU and controversy on how far European integration should go, is that this should be the case in the EU, but systematic empirical evidence on this claim is currently lacking.

It is possible that citizens hold strong priors on the issue of climate governance and associated agreements. If survey participants hold such strong priors, nuances such as the properties of decision and domestic implementation rules may seem less relevant and may be overlooked when citizens form their legitimacy perceptions (see Hyde, Kelley, and Neilson this volume). Indeed, when regressing our survey participants' climate concern on the three measures of legitimacy, we found a significant relationship. Overall, it is possible that these priors have made it hard for the authority shift to "cut through".

What do our findings mean for policy making? In light of the points just made, they suggest that rather subtle shifts of authority from national to global governance institutions, in themselves, are unlikely to create a political backlash and result in a loss of legitimacy. However, if these shifts are popularized as “negative” by elites or the media, such as in the case of the United Kingdom's role in the EU, and these critiques are salient to citizens, shifting authority could induce a backlash. That is, shifts in authority might not per se affect legitimacy, though policymakers could still frame these shifts positively or negatively and thus affect perceived legitimacy (see Dellmuth and Tallberg, this volume).

With respect to global climate policy in particular, and from the perspective of our findings, the current trend towards decreasing authority of the global climate governance framework under the 2015 Paris Agreement might be unwarranted. Most citizens do not seem to mind increasing the authority of the global climate governance framework. And for those that do, increases in authority seem to enhance their legitimacy perceptions. 


\section{References}

Anderson, Kenneth, and Anne-Marie Slaughter. 2005. Squaring the circle? Reconciling sovereignty and global governance through global government networks. Harvard Law Review 118(4):12551312.

Bernauer, Thomas. 2013. Climate change politics. Annual Review of Political Science 16:421-448.

Bernauer, Thomas and Robert Gampfer. 2013. Effects of civil society involvement on popular legitimacy of global environmental governance. Global Environmental Change 23(2):439-449.

Bernstein, Steven. 2011. Legitimacy in intergovernmental and non-state global governance. Review of International Political Economy 18(1):17-51.

Blake, Daniel J., and Autumn Lockwood Payton. 2015. Balancing design objectives: Analyzing new data on voting rules in intergovernmental organizations. The Review of International Organizations 10(3): 377-402.

Blondel, Jean, Richard Sinnott, and Palle Svensson. 1998. People and Parliament in the European Union: participation, democracy, and legitimacy. Oxford: Oxford University Press.

Bodansky, Daniel. 1999. The Legitimacy of International Governance: A Coming Challenge for International Environmental Law? American Journal of International Law 93(3): 596-624.

Bulkeley, Harriet, and Peter Newell. 2015. Governing climate change. NewYork, NY: Routledge.

Caplan, Bryan. 2001. Rational irrationality and the microfoundations of political failure. Public Choice 107(3-4): 311-331.

Chalmers, Adam W., and Lisa M. Dellmuth. 2015. Fiscal redistribution and public support for European integration. European Union Politics 16(3): 386-407.

Chong, Dennis, and James N. Druckman. 2007. Framing theory. Annual Review Political Science 10: 103-126.

Council of Foreign Relations, 2015. Two Cheers for the Paris Agreement on Climate Change (December 12). Available at <http://blogs.cfr.org/levi/2015/12/12/two-cheers-for-the-parisagreement-on-climate-change/ > . Accessed 2 August 2016

Dalton, Russell J. 1984. Cognitive mobilization and partisan dealignment in advanced industrial democracies. The Journal of Politics 46 (1): 264-284.

Della Porta, Donatella, Massimiliano Andretta, Lorenzo Mosca, and Herbert Reiter. 2006. Globalization from below: Transnational activists and protest networks. London: University of Minnesota Press.

Dellmuth, Lisa Maria, and Jonas Tallberg. 2015. The social legitimacy of international organisations: Interest representation, institutional performance, and confidence extrapolation in the United Nations. Review of International Studies 41(3): 451-475. 
Dellmuth, Lisa Maria and Jonas Tallberg. This issue. Elite Communication and Popular Legitimacy in Global Governance.

Dingwerth, Klaus, Hennig Schmidtke, and Weise Weise. This issue. Speaking Democracy: Why International Organizations Adopt a Democratic Rhetoric.

Dimitrov, Radoslav S. 2010. Inside Copenhagen: The State of Climate Governance. Global Environmental politics 10(2): 18-24.

Doherty, David, and Jennifer Wolak. 2012. When do the ends justify the means? Evaluating procedural fairness. Political Behavior 34(2): 301-323.

Downs, Anthony. 1984. An economic theory of political action in a democracy. The Political Economy: Readings in the politics and economics of American public policy, edited by Thomas Ferguson and Joel Rogers, 12-26. Armonk, NY: M. E. Sharpe Publishers.

Edwards, Martin S. 2009. Public support for the international economic organizations: Evidence from developing countries. The Review of International Organizations 4(2): 185-209.

Ecker-Ehrhardt, Matthais and Wessels, Berhard. 2013. Input-oder Output-Politisierung internationaler Organisationen. Der kritische Blick der Bürger auf Demokratie und Leistung. Gesellschaftliche Politisierung und internationale Institutionen, edited by Mike Zürn and Matthais Ecker-Ehrhardt. Berlin: Suhrkamp Verlag Berlin.

Ecker-Ehrhardt, Matthias. 2012. Cosmopolitan politicization: How perceptions of interdependence foster citizens' expectations in international institutions. European Journal of International Relations 18(3): 481-508.

Eichenberg, Richard C., and Russell J. Dalton. 2007. Post-Maastricht blues: The transformation of citizen support for European integration, 1973-2004. Acta politica 42(2): 128-152.

Esty, Daniel C. 2002. The World Trade Organization's legitimacy crisis. World Trade Review 1(1): 7-22.

Falk, Richard, and Andrew Strauss. 2001. Toward global parliament. Foreign Affairs. January/Febuary: 212-220.

Gabel, Matthew, and Kenneth Scheve. 2007. Estimating the Effect of Elite Communications on Public Opinion Using Instrumental Variables. American Journal of Political Science. 51(4): 10131028.

Gallup International Association. 2005. Voice of the People. ICPSR04636-v1. Zürich: Gallup International Association.

Gibson, James L., and Gregory A. Caldeira. 1995. The Legitimacy of the Court of Justice in the European Union: Models of Institutional Support. American Political Science Review 89(2): 356376. 
Grant, Ruth W., and Robert O. Keohane. 2005. Accountability and abuses of power in world politics. American political science review 99(1): 29-43.

Held, David and Koenig-Archibugi, Mathias, eds. 2005. Global governance and public accountability. Oxford, UK: Blackwell Publishing.

Hessami, Zohal. 2011. What Determines Trust in International Organizations? An Empirical Analysis for the IMF, the World Bank, and the WTO. Working Paper 44. Konstanz, Germany: Department of Economics, University of Konstanz.

Hibbing, John R., and Elizabeth Theiss-Morse. 2002. Stealth democracy: Americans' beliefs about how government should work. Cambridge: Cambridge University Press.

Hickmann, Thomas. 2016. Rethinking Authority in Global Climate Governance: How Transnational Climate Initiatives Relate to the International Climate Regime. New York, NY: Routledge.

Hobolt, Sara B. 2012. Public opinion and integration. In The Oxford Handbook of the European Union, edited by Erik Jones, Anand Menon, and Stephen Weatherill. Oxford: Oxford University Press.

Holcombe, Randall G. 2006. Should We Have Acted Thirty Years Ago to Prevent Global Climate Change?. The Independent Review 11(2): 283.

Hooghe, Liesbet, and Gary Marks. 2005. Calculation, community and cues public opinion on European integration.European Union Politics 6(4): 419-443.

Hooghe, Liesbet, and Gary Marks. 2009. A postfunctionalist theory of European integration: From permissive consensus to constraining dissensus. British Journal of Political Science 39(1): 1-23.

Hooghe, Liesbet, and Gary Marks. 2015. Delegation and pooling in international organizations. The Review of International Organizations 10(3): 305-328.

Hyde, Susan, Judith Kelley, and Daniel Nielson. This issue. The Sources of Perceived Legitimacy for Election Observation Organizations: Three Experiments on Non- Governmental Organizations.

Inglehart, Ronald. 1970. Cognitive mobilization and European identity. Comparative Politics 3(1): 45-70.

Inglehart, Ronald. 1977. The silent revolution: Changing values and political styles among Western publics. Vancouver. Princeton University Press.

Johnson, Tana. 2011. Guilt by association: The link between states' influence and the legitimacy of intergovernmental organizations. The Review of International Organizations 6(1): 57-84.

Keohane, Robert O. and Joseph S. Nye. 2003. Redefining accountability for global governance. In Governance in a global economy: political authority in transition, edited by Miles Kahler and David A. Lake, 386-411. New Haven, CT: Princeton University Press. 
Keohane, Robert O., and David G. Victor. 2011. The regime complex for climate change. Perspectives on politics 9(1): 7-23.

Koppell, Jonathan GS. 2008. Global governance organizations: Legitimacy and authority in conflict. Journal of Public Administration Research and Theory 18(2): 177-203.

Levi, Margaret, and Gillian H. Murphy. 2006. Coalitions of contention: The case of the WTO protests in Seattle. Political Studies 54(4): 651-670.

Li, Kui-Wai. 2003. Capitalist Development and Economism in East Asia: The Rise of Hong Kong, Singapore, Taiwan and South Korea. New York, NY: Routledge.

Lidskog, Rolf, and Ingemar Elander. 2010. Addressing climate change democratically. Multi- level governance, transnational networks and governmental structures. Sustainable Development 18(1): 32-41.

Lupia, Arthur. 2015. Uninformed: Why People Seem to Know So Little about Politics and What We Can Do about It. New York, NY: Oxford University Press.

McLaren, Lauren M. 2002. Public support for the European Union: cost/benefit analysis or perceived cultural threat? The Journal of Politics 64(2): 551-566.

Norris, Pippa. 2000. Global governance and cosmopolitan citizens. In Governance in a globalizing world, edited by Joseph S. Nye Jr. and John D. Donahue, 155-177. Harrisburg, VA: Brookings Institution Press.

Pew Research Center. November 2015. Global Concern about Climate Change, Broad Support for Limiting Emissions. Available at < http://www.pewglobal.org/2015/11/05/global-concern-aboutclimate-change-broad-support-for-limiting-emissions/ >. Accessed 2 August 2016

Rauh, Christian and Michael Zürn. This issue. Legitimation and Delegitimation of Global Economic Governance? Civil Society Evaluations of the IMF, the World Bank, and the WTO in the International Press.

Rogelj, Joeri, Malte Meinshausen, and Reto Knutti. 2012. Global warming under old and new scenarios using IPCC climate sensitivity range estimates. Nature climate change 2(4): 248-253

Shively, Phillips. 1979. The development of party identification among adults: Exploration of a functional model. American Political Science Review 73.04: 1039-1054.

Schlipphak, Bernd. 2015. Measuring attitudes toward regional organizations outside Europe. The Review of International Organizations 10(3): 351-375.

Scholte, Jan Aart. Civil society and legitimation of global governance. 2007. Journal of Civil Society 3 (3): 305-326.

Schneider, Steffen, Henning Schmidtke, and Frank Nullmeier. This issue. From Permissive Consensus to Constraining Dissensus? Elite Discourse on the Legitimacy of International Organizations.

Scott, Richard. 2013. Institutions and organizations: Ideas, interests, and identities. London:Sage 
Publications.

Semenza, Jan C., Daniel J. Wilson, Jeremy Parra, Brian D. Bontempo, Melissa Hart, David J. Sailor, and Linda A. George. 2008. Public perception and behavior change in relationship to hot weather and air pollution. Environmental Research 107(3): 401-411.

Slaughter, Anne-Marie. 2005. Winning Back the World’s Trust. Global Agenda:1-5.

Suchman, Mark C. 1995. Managing legitimacy: Strategic and institutional approaches. Academy of management review 20(3): 571-610.

Tallberg, Jonas and Michael Zürn. This issue. Legitimacy and Legitimation in International Organizations.

Vihma, Antto. 2011. A climate of consensus: The UNFCCC faces challenges of legitimacy and effectiveness. Briefing Paper 75. Helsinki, Finland: Finnish Institute for International Affairs.

Voeten, Erik. 2013. Public Opinion and the Legitimacy of International Courts. Theoretical Inquiries in Law 14(2): 411-436.

Wilkinson, Rorden, and Stephen Hughes, eds. 2002. Global governance: Critical perspectives. Abindgon (Oxon): Psychology Press.

Wolf, Klaus Dieter. 2007. 11 Private actors and the legitimacy of governance beyond the state. in: Governance and Democracy: Comparing national, European and international experiences, edited by Arthur Benz and Yannis Papadopoulos, 200 - 227. Oxford: Taylor and Francis Group.

Zürn, Michael. 2015. Beyond Anarchy: Authority and Rule in Global Governance. Politische Vierteljahresschrift 56(2): 319-333.

Zürn, Michael, Martin Binder, and Matthias Ecker-Ehrhardt. 2012. International Authority and Its Politicization. International Theory 4(1): 69-106. 


\section{International Voting Rule}

\begin{tabular}{l}
\hline Majority \\
\hline At the meeting, countries negotiate their \\
positions and draft a proposed agreement. Once \\
countries complete these negotiations, they will \\
vote for or against a proposed agreement. As \\
mentioned before, the proposed agreement \\
focuses on two issues:
\end{tabular}

- How much should worldwide carbon dioxide (CO2) emissions be reduced?

- How much should each country reduce its carbon dioxide (CO2) emissions to achieve the worldwide goal?

The voting rule is as follows:

- If more than half of the participating countries (the majority) vote in favor of the proposed agreement, then the proposed agreement will pass and negotiations will end even if [the United States/Germany] voted against.

- If more than half of the participating countries vote against the proposed agreement, then the proposed agreement will not pass even if [the United States/Germany] voted in favor. In that case, there is no agreement and countries will resume negotiations next year.

\section{Consensus}

At the meeting, countries negotiate their positions and draft a proposed agreement. Once countries complete these negotiations, they will vote for or against a proposed agreement. As mentioned before, the proposed agreement focuses on two issues:

- How much should worldwide carbon dioxide (CO2) emissions be reduced?

- How much should each country reduce its carbon dioxide (CO2) emissions to achieve the worldwide goal?

The voting rule is the following:

- If all participating countries (unanimity) vote in favor of the proposed agreement, then the proposed agreement will pass and negotiations will end as long as [the United States/Germany] also votes in favor.

- If any participating country votes against the proposed agreement, then the proposed agreement will not pass even if [the United States/Germany] voted in favor. In that case, there is no agreement and countries will resume negotiations next year.

\section{Domestic Ratification Procedure}

\begin{tabular}{|c|c|}
\hline Automatic Implementation & Legislature \\
\hline $\begin{array}{l}\text { Once international negotiations end and if an } \\
\text { agreement passes, the agreement needs to be } \\
\text { implemented within participating countries (at } \\
\text { the domestic level). Imagine that all countries } \\
\text { participating in the Global Climate Conference, } \\
\text { including [the United States/Germany], decided } \\
\text { before the negotiations to automatically } \\
\text { implement an agreement if one is passed. This } \\
\text { means that if the Conference passes an } \\
\text { agreement, [the United States/Germany] must } \\
\text { reduce its carbon dioxide (CO2) emissions by the } \\
\text { amount specified in that agreement. However, if } \\
\text { the Conference does not pass an agreement, [the }\end{array}$ & $\begin{array}{l}\text { Once international negotiations end and if an } \\
\text { agreement passes, the agreement needs to be } \\
\text { implemented within participating countries (at } \\
\text { the domestic level). Imagine that all countries } \\
\text { participating in the Global Climate Conference, } \\
\text { including the United States, decided before the } \\
\text { negotiations to implement an agreement reached } \\
\text { by the Conference only after their respective } \\
\text { parliament/legislature back home has approved } \\
\text { the agreement as well. This means that if } \\
\text { [Congress/ Bundestag or Bundesrat] approves } \\
\text { the agreement, [the United States/Germany] must } \\
\text { reduce its carbon dioxide (CO2) emissions by the }\end{array}$ \\
\hline
\end{tabular}


United States/Germany] has no obligation to reduce its carbon dioxide (CO2) emissions. amount specified in that agreement. However, if [Congress/ Bundestag or Bundesrat] does not approve the agreement, [the United States/Germany] has no obligation to reduce its carbon (CO2) emissions.

Table 1: Treatments in the English survey. German translations can be found in SI-7 (Supplementary Information Section 7). Participants were randomly assigned to either the Majority or Consensus treatment and then randomly assigned to the Automatic Implementation or Legislature treatment.

\begin{tabular}{|l|l|l|l|l|}
\hline & $\begin{array}{l}\text { Consensus- } \\
\text { Legislature }\end{array}$ & $\begin{array}{l}\text { Consensus- } \\
\text { Automatic }\end{array}$ & $\begin{array}{l}\text { Majority- } \\
\text { Automatic }\end{array}$ & $\begin{array}{l}\text { Majority- } \\
\text { Legislature }\end{array}$ \\
\hline Germany & $404(0.90)$ & $406(0.83)$ & $390(0.82)$ & $400(0.84)$ \\
\hline USA & $403(0.86)$ & $386(0.73)$ & $406(0.74)$ & $405(0.84)$ \\
\hline
\end{tabular}

Table 2: Number of participants in each group. The percentage in brackets indicates the number of participants who answered all three comprehension questions correctly by their second attempt.

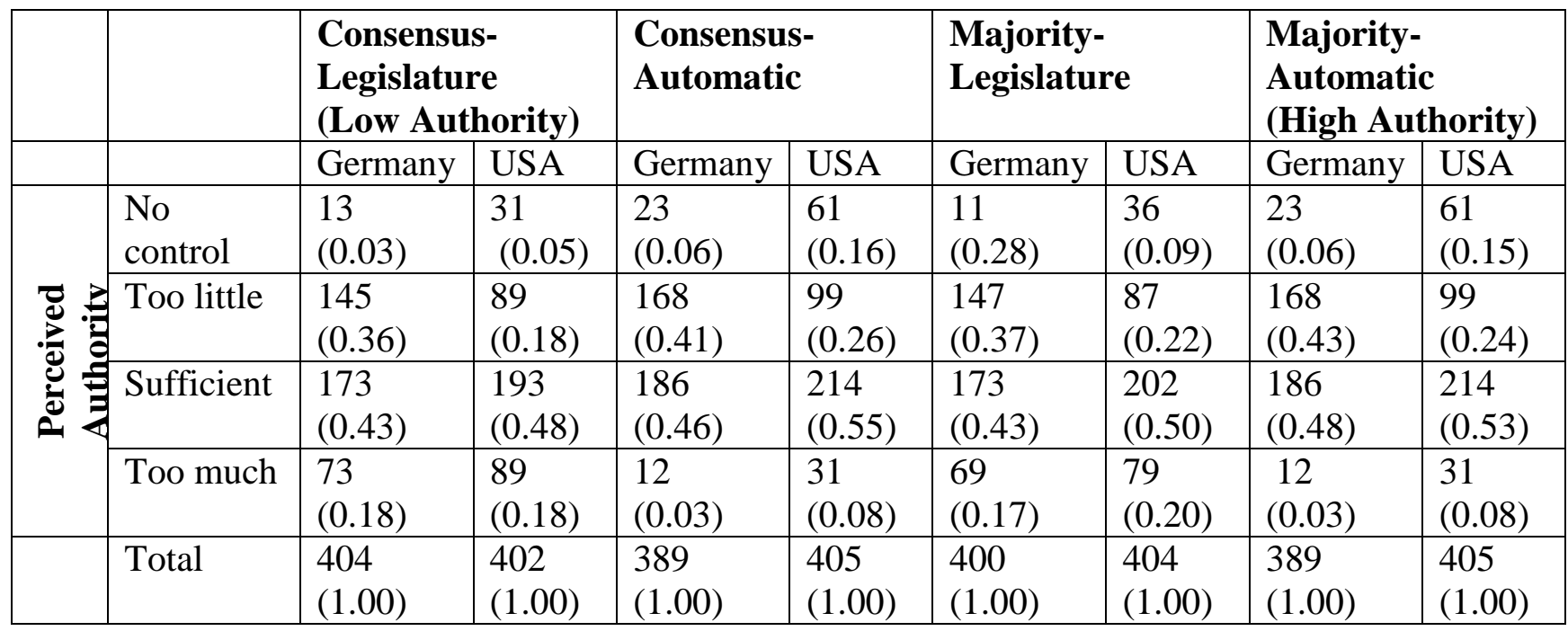

Table 3: How participants in each treatment perceive authority. The vertical column lists the answer categories to the manipulation check question: do you think this process of deciding whether and how much [the United States/Germany] must reduce its carbon dioxide emissions gives [the United States/Germany] too little or too much control over this policy? The whole number is the total number of participants from each country in each treatment by how they perceive authority, and the number in parentheses is the percentage.

\section{APPROPRIATE DEFERENCE}

\section{5-ITEM}

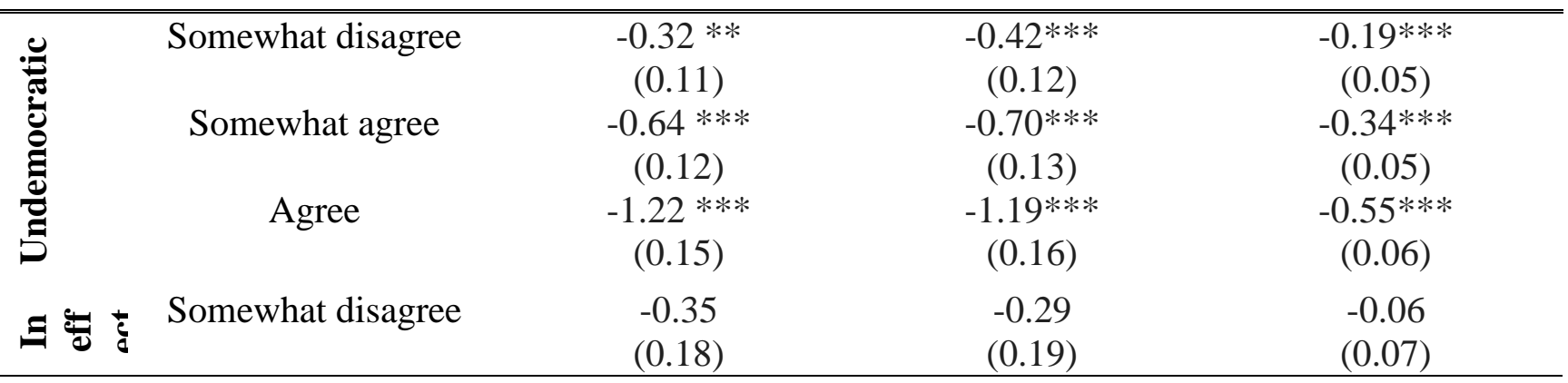




\begin{tabular}{|c|c|c|c|c|}
\hline \multirow{14}{*}{ 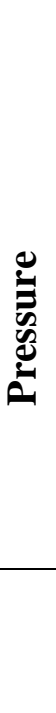 } & Somewhat agree & $\begin{array}{c}-0.47 * * \\
(0.17)\end{array}$ & $\begin{array}{l}-0.43^{*} \\
(0.18)\end{array}$ & $\begin{array}{l}-0.10 \\
(0.07)\end{array}$ \\
\hline & \multirow[t]{2}{*}{ Agree } & $-1.20 * * *$ & $-1.08 * * *$ & $-0.40 * * *$ \\
\hline & & $(0.18)$ & $(0.19)$ & $(0.07)$ \\
\hline & \multirow[t]{2}{*}{ Somewhat disagree } & $-0.50 * * *$ & $-0.61 * * *$ & $-0.23 * * *$ \\
\hline & & $(0.12)$ & $(0.13)$ & $(0.05)$ \\
\hline & \multirow[t]{2}{*}{ Somewhat agree } & $-0.67 * * *$ & $-0.99 * * *$ & $-0.42 * * *$ \\
\hline & & $(0.13)$ & $(0.14)$ & $(0.06)$ \\
\hline & \multirow[t]{2}{*}{ Agree } & $-1.65 * * *$ & $-1.84 * * *$ & $-0.82 * * *$ \\
\hline & & $(0.15)$ & $(0.15)$ & $(0.06)$ \\
\hline & \multirow[t]{2}{*}{ USA } & $-0.07 * * *$ & $-0.73 * * *$ & $-0.23 * * *$ \\
\hline & & $(0.09)$ & $(0.09)$ & $(0.04)$ \\
\hline & $\mathbf{N}$ & $2119^{8}$ & 2119 & 2119 \\
\hline & Link & logit & logit & \\
\hline & AIC & 4630.04 & 4292.11 & 5481.32 \\
\hline
\end{tabular}

Table 4: Effects of perceived procedural quality and performance on legitimacy. ${ }^{* * *} \mathrm{p}<0.001,{ }^{* *} \mathrm{p}<0.01,{ }^{*} \mathrm{p}<0.05$. We used an ordinal logistic regression to calculate the results for APPROPRIATE and DEFERENCE. The coefficients cannot be interpreted directly. We use OLS regression to calculate the results for the 5-ITEM variable. This is why there is a link function for APPROPRIATE and DEFERENCE and not for the 5-ITEM measure.

\begin{tabular}{|l|l|l|}
\hline & Selected & Not selected \\
\hline Voting rule is undemocratic & 0.26 & 0.74 \\
\hline $\begin{array}{l}\text { Implementation procedure is } \\
\text { undemocratic }\end{array}$ & 0.36 & 0.64 \\
\hline $\begin{array}{l}\text { Countries in negotiations are } \\
\text { undemocratic }\end{array}$ & 0.41 & 0.59 \\
\hline $\begin{array}{l}\text { Negotiations are dominated by } \\
\text { business interests }\end{array}$ & 0.39 & 0.61 \\
\hline
\end{tabular}

Table 5: Reasons why survey participants view the Global Climate Conference as undemocratic

\begin{tabular}{|l|l|l|}
\hline & Selected & Not selected \\
\hline Voting rule is democratic & 0.65 & 0.35 \\
\hline $\begin{array}{l}\text { Implementation procedure is } \\
\text { democratic }\end{array}$ & 0.41 & 0.59 \\
\hline $\begin{array}{l}\text { Countries in negotiations are } \\
\text { democratic }\end{array}$ & 0.29 & 0.71 \\
\hline Negotiations are dominated by & 0.17 & 0.93 \\
\hline
\end{tabular}

\footnotetext{
${ }^{8}$ These questions were at the end of the survey and optional for participants, which is why 1081 participants did not respond. We conducted ANOVA analyses to check for significant differences between those who did and did not respond to these three questions. Those who are somewhat, very, or extremely interested were more likely to respond to these questions, while those who are not interested were more likely to skip. In addition, males were more likely to respond than females. There were no significant differences between those who did and did not respond in regards to treatments, climate concern, country or age.
} 
business interests

Table 6: Reasons why survey participants view the Global Climate Conference as democratic 


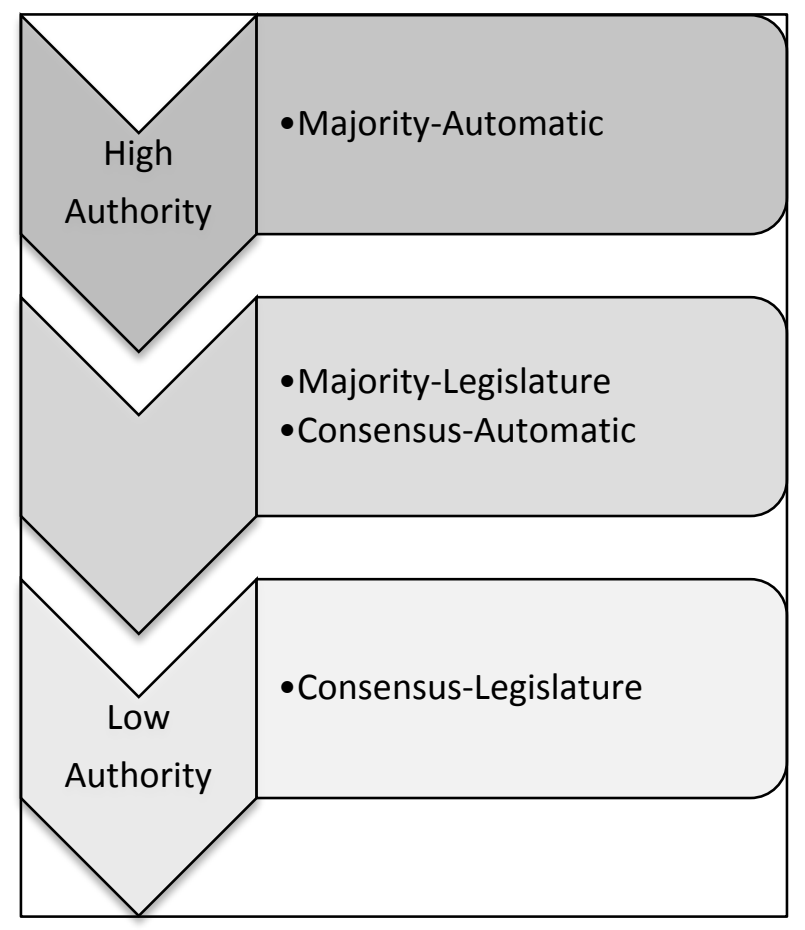

Figure 1: Treatments by levels of authority

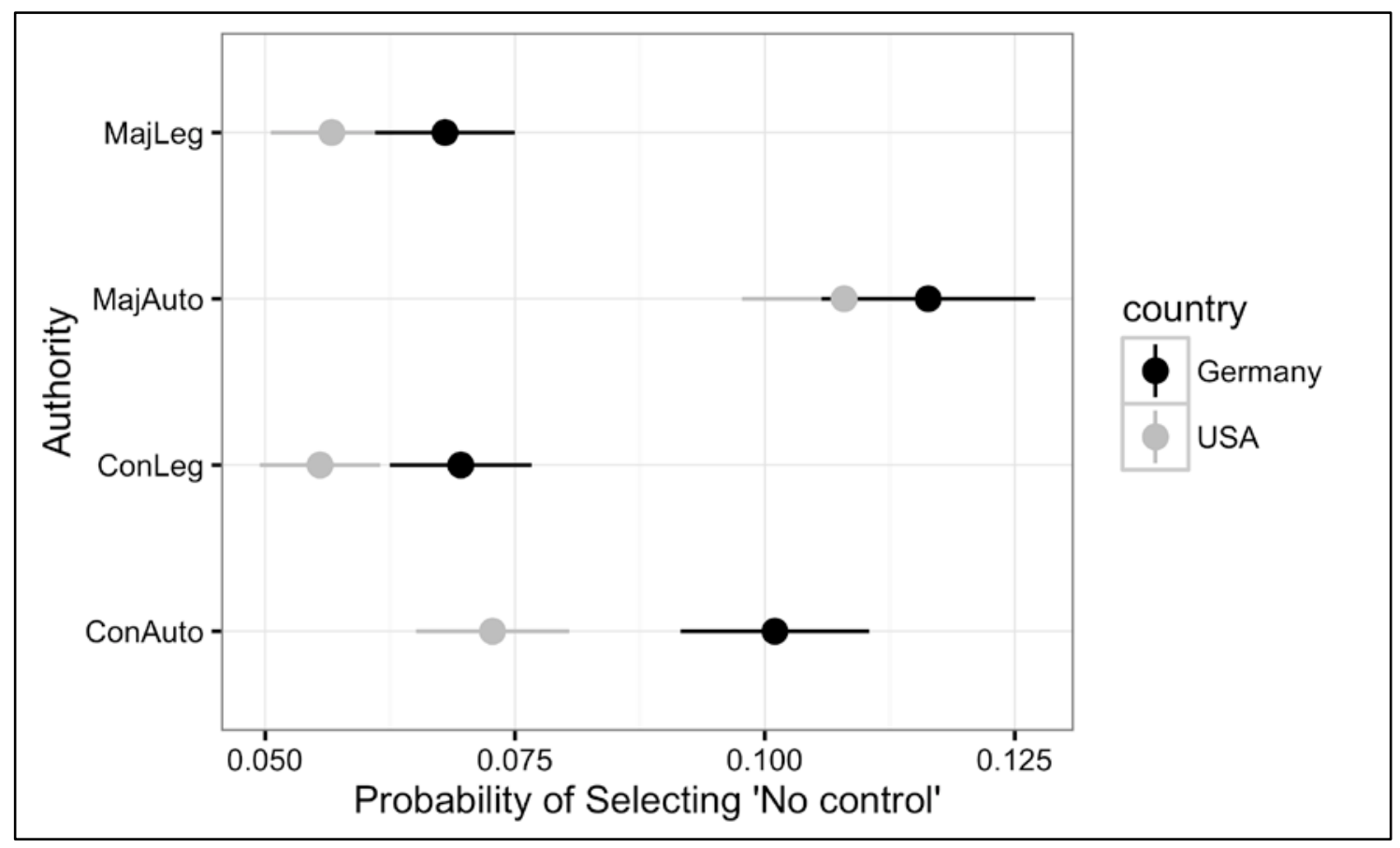

Figure 2: Probability of selecting no control in response to the manipulation check. We conducted an ordinal logistic regression using manipulation check as the dependent variable and the treatments as well as country as the independent variables. We then estimated the predicted probabilities of selecting no control under the different treatments for each country. See SI-1 for the predicted probabilities of selecting the other answer categories. 


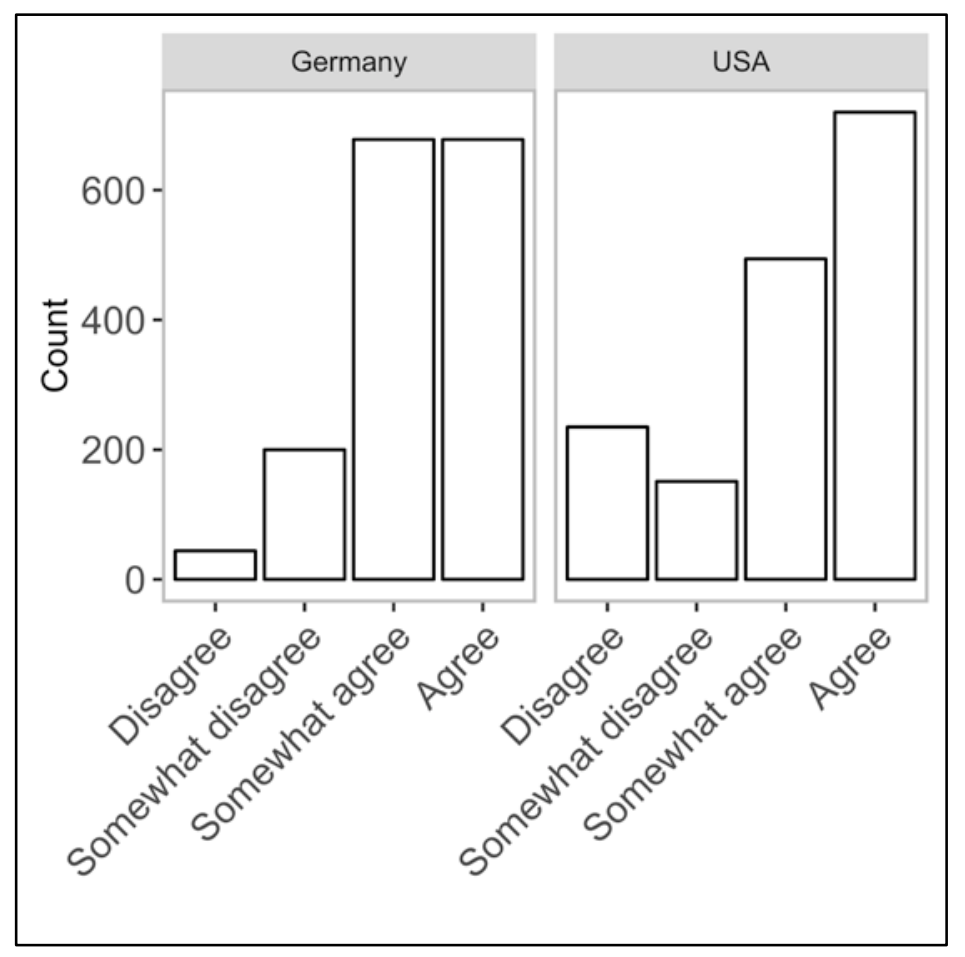

Figure 3: Distribution of responses to APPROPRIATE for German and American samples

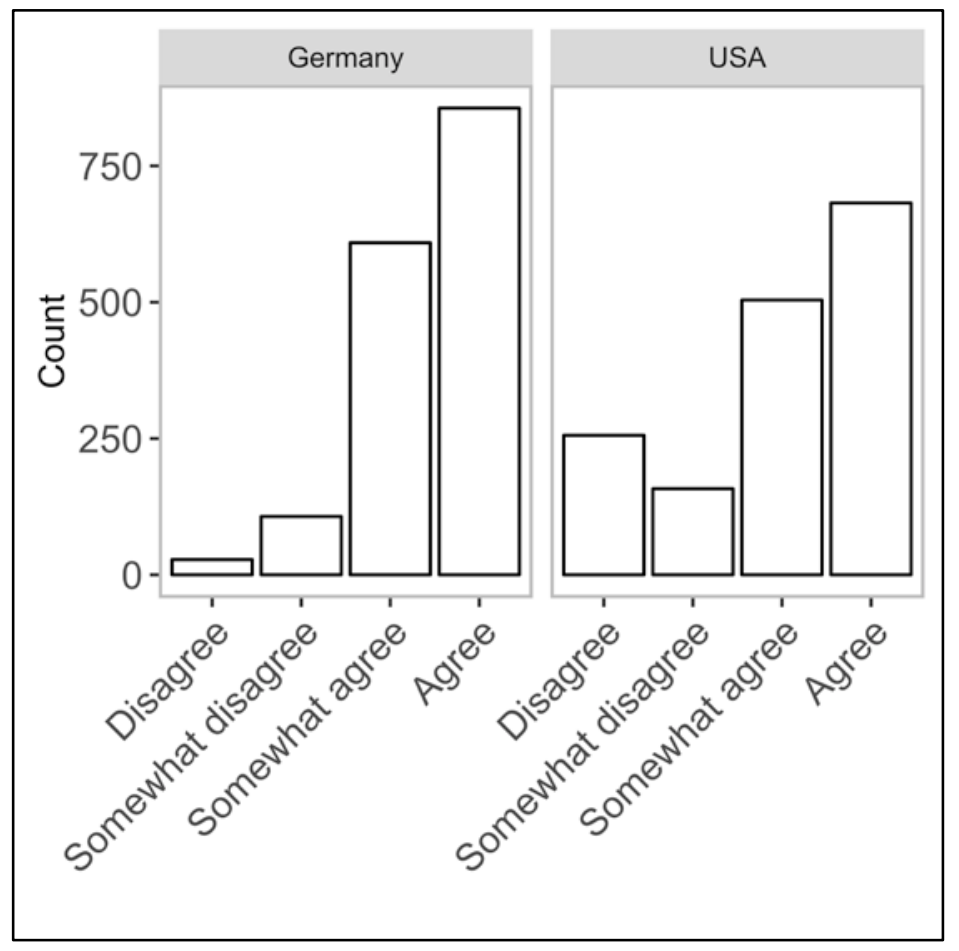

Figure 4: Distribution of responses to DEFERENCE for German and American samples. 


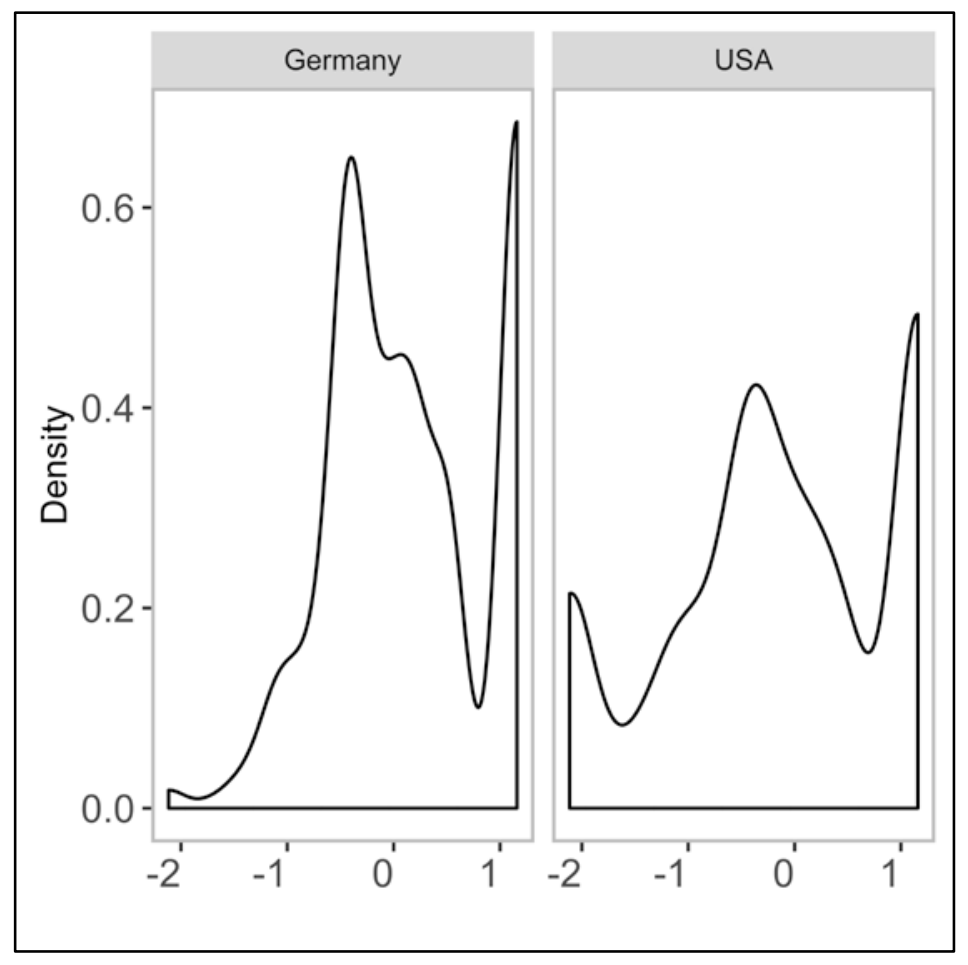

Figure 5: Distribution of 5-ITEM legitimacy measure for German and American samples. Negative values indicate low levels of perceived legitimacy while positive indicate high levels. 


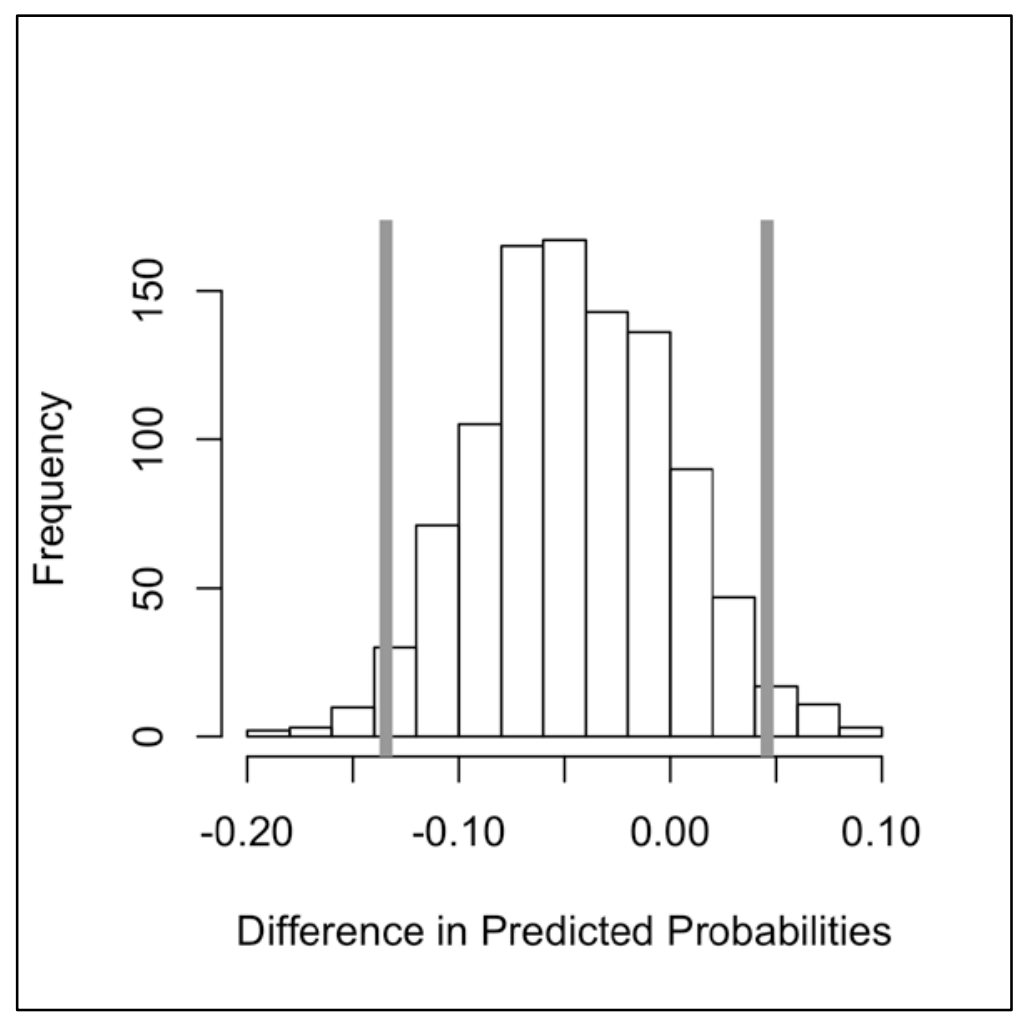

Figure 6: Difference in probability of agreeing between Consensus-Legislature (i.e., status quo) and Majority-Automatic (i.e., high pooling of authority) over 1000 iterations for the full American sample

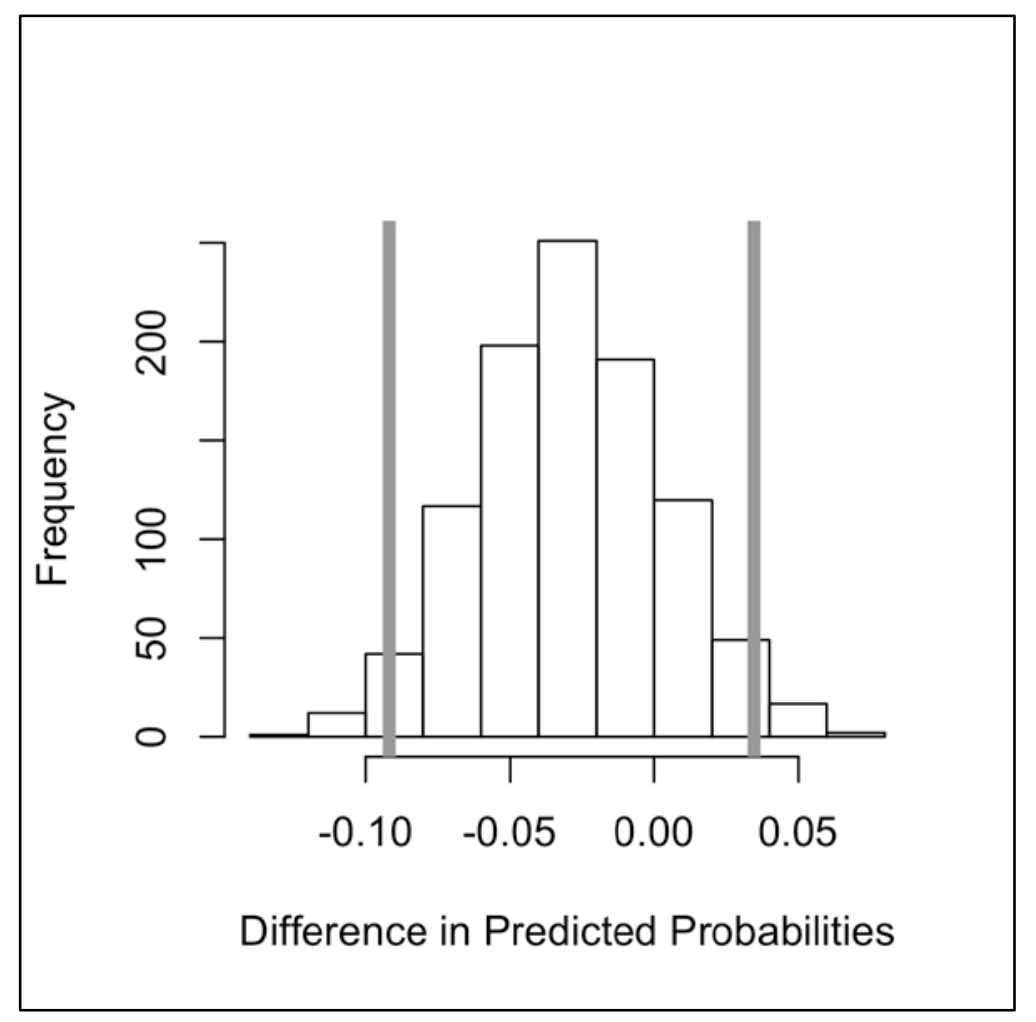

Figure 7: Difference in predicted probability of agreeing between Consensus-Legislature (i.e., status quo) and MajorityAutomatic (i.e., high pooling of authority) over 1000 iterations for the full German sample 


\section{Supplementary Information}

Does International Pooling of Authority Undermine the Legitimacy of Global Governance?

\section{Table of Contents:}

SI-1 Manipulation Check Probability Plots

SI-2 5-ITEM Dependent Variable: IRT Results

SI-3 Construction of US Sample

SI-4 Main Effects

SI-4 (a) Moderating Effects: Cognitive Mobilization

SI - 4 (b) Alternative measures of cognitively mobilization: Education

SI-5 (a) Interaction of Authority and Perceived Authority

SI-5 (b) Interaction between Authority and Political Ideology

SI-6 Other factors influencing legitimacy perceptions

SI-7 Survey Questions

SI-8 Robustness checks 
To understand if participants perceived the continuum of authority as intended, we asked: Do you think this process of deciding whether and how much [the United States/Germany] must reduce its carbon dioxide emissions gives [the United States/Germany] too little or too much control over this policy? (No control, too little control, sufficient control, too much control). The probability of American and German participants in the full samples selecting too little, sufficient, and too much" control are below in Table SI-1.1, SI-1.2, and SI-1.3, respectively. The probability of participants selecting no control is in the Section 3.2.

Participants in Germany and the USA are significantly more likely to select too little control after the Majority-Automatic treatment than the Consensus-Legislature treatment. Likewise, participants are significantly more likely to select sufficient or too much control after the Consensus-Legislature than Majority-Automatic treatment in both countries. The results are less clear for Majority-Legislature and Consensus-Automatic treatments. The differences in probability of selecting too little, sufficient, or too much control are insignificant for Majority-Legislature and Consensus-Legislature treatments in Germany and the United States. The probability of selecting too little control is significantly higher for the Consensus-Automatic treatment compared to Consensus-Legislature treatment and significantly lower compared to the Majority-Automatic treatment for the American sample. Results are similar for the German sample, but there is no significant difference in the probability of selecting too little control for Consensus-Automatic and Majority-Automatic. There are similar results for the probability of selecting sufficient and too much control. For these reasons, we can conclude that participants, at a minimum, understood the extremes of the continuum of authority.

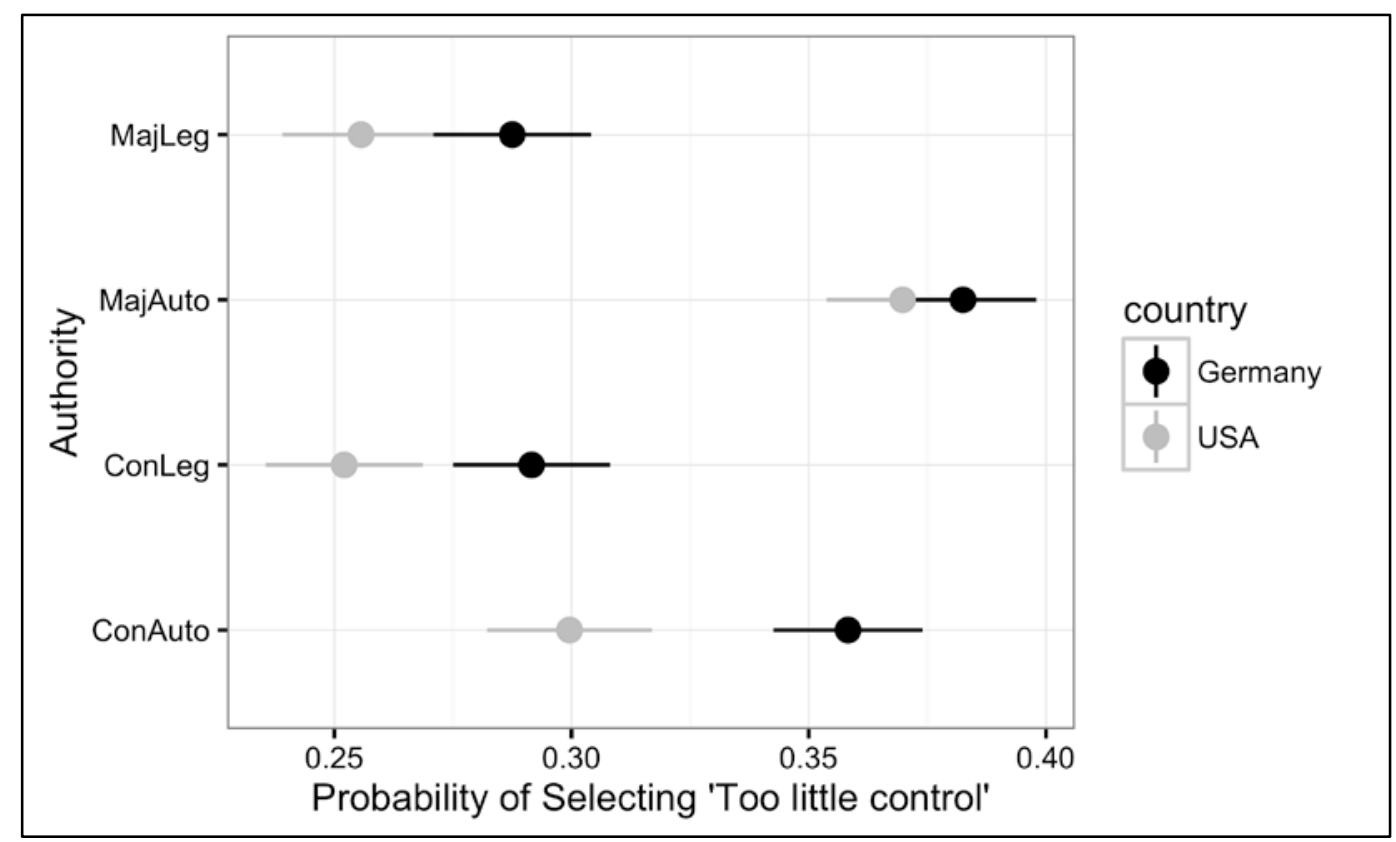

Table SI-1.1: The probability of German and American participants in the full sample selecting too little control. 


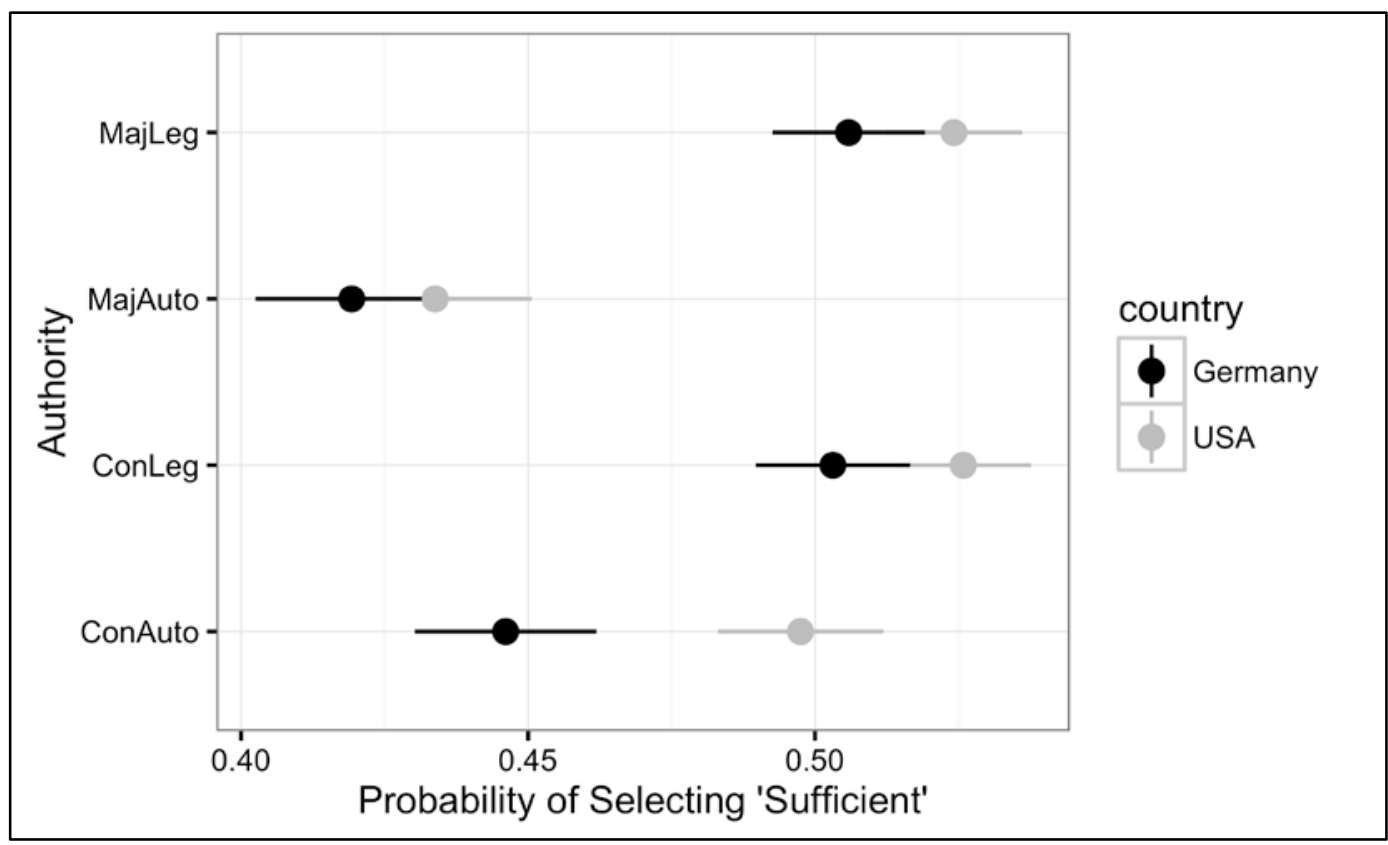

Table SI-1.2: The probability of German and American participants in the full sample selecting sufficient control.

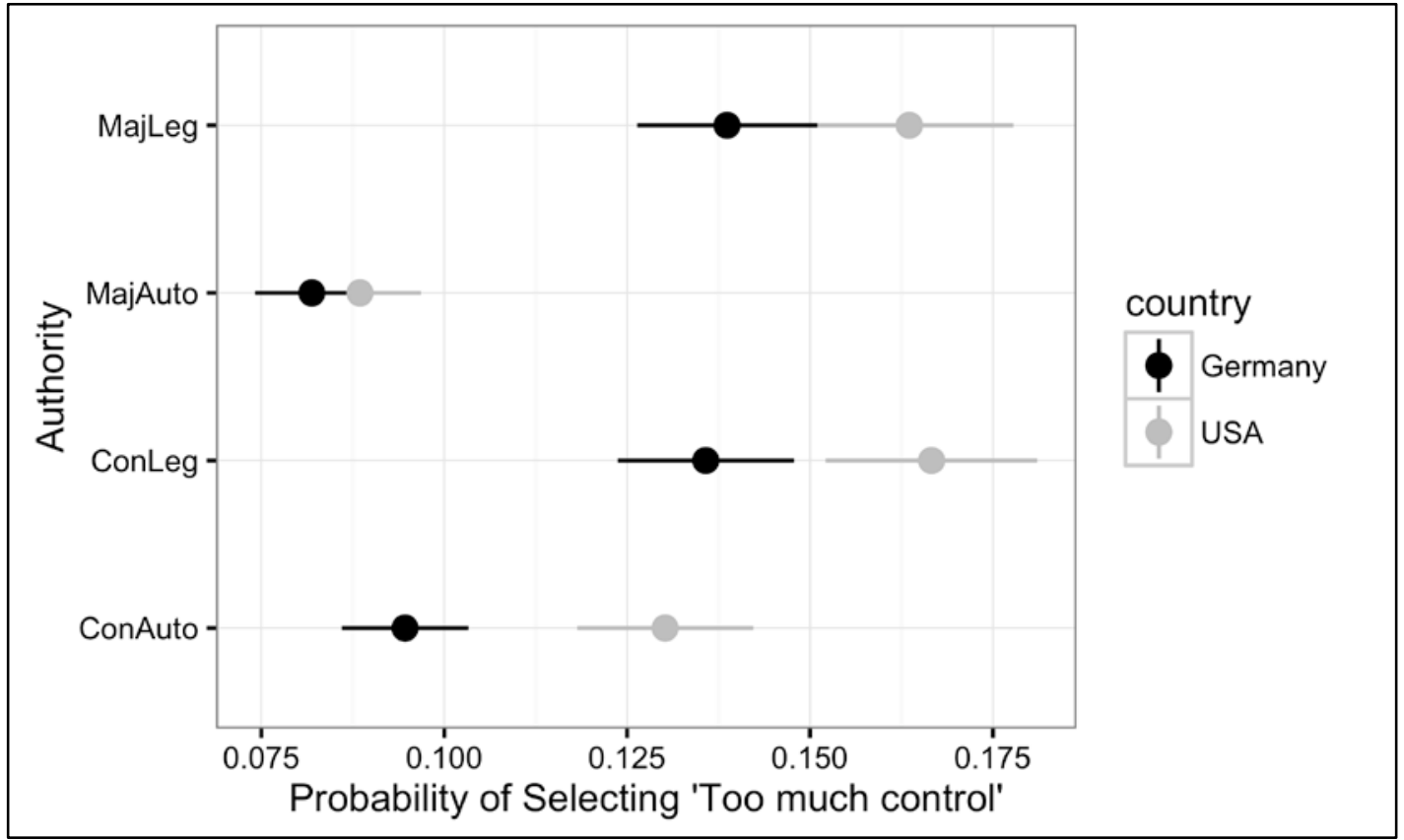

Table SI-1.3: The probability of German and American participants in the full sample selecting too much control. 
We calculated individuals' legitimacy perceptions using Item Response Theory (IRT). Specifically, we used a Generalized Partial Credit Model because of the ordinal nature of the data. In IRT, an individual's score represents the magnitude of the latent trait of the individual, which in this study, is their legitimacy perception of the climate governance framework. A benefit of IRT is it allows items to contribute differently to the latent trait unlike other aggregation techniques.

First, we need to confirm that our items measure one latent trait. Results from the IRT show that 85 percent of the variance is explained by one dimension. The factor loadings are:

\begin{tabular}{|l|c|}
\hline & Factor 1 \\
\hline $\begin{array}{l}\text { The principles of the Global Climate } \\
\text { Conference match my own. }\end{array}$ & 0.908 \\
\hline $\begin{array}{l}\text { I sympathize with the goals of the Global } \\
\text { Climate Conference. }\end{array}$ & 0.893 \\
\hline $\begin{array}{l}\text { I believe the Global Climate Conference is } \\
\text { necessary. }\end{array}$ & 0.965 \\
\hline $\begin{array}{l}\text { I think the GCC serves an important role in } \\
\text { society. }\end{array}$ & 0.900 \\
\hline $\begin{array}{l}\text { The GCC should continue to make decisions in } \\
\text { the future. }\end{array}$ & 0.955 \\
\hline SS Loadings & $\mathbf{4 . 2 7 6}$ \\
\hline Proportion of Variance & $\mathbf{0 . 8 5 5}$ \\
\hline
\end{tabular}

Table SI-2.1 Factor loadings from the GPCM

GPCM also calculates difficulty and discrimination parameters. The number of discrimination parameters is $M-1$ where $M$ is equal to the number of answer categories. Using the difficulty parameters, we can identify which items are contributing most to scoring the latent trait.

\begin{tabular}{|l|c|c|c|c|}
\hline & $\begin{array}{c}\text { Discrimination } \\
\text { Parameter }\end{array}$ & $\begin{array}{c}\text { Difficulty } \\
\text { Parameter 1 }\end{array}$ & $\begin{array}{c}\text { Difficulty } \\
\text { Parameter 2 }\end{array}$ & $\begin{array}{c}\text { Difficulty } \\
\text { Parameter 3 }\end{array}$ \\
\hline $\begin{array}{l}\text { The principles of the } \\
\text { Global Climate } \\
\text { Conference match my } \\
\text { own. }\end{array}$ & 3.679 & 4.938 & 8.124 & 6.84 \\
\hline $\begin{array}{l}\text { I sympathize with the } \\
\text { goals of the Global } \\
\text { Climate Conference. }\end{array}$ & 3.384 & 4.814 & 8.45 & 8.284 \\
\hline $\begin{array}{l}\text { I believe the Global } \\
\text { Climate Conference is } \\
\text { necessary. }\end{array}$ & 6.254 & 8.409 & 14.274 & 15.074 \\
\hline $\begin{array}{l}\text { I think the GCC serves } \\
\text { an important role in } \\
\text { society. }\end{array}$ & 3.518 & 4.875 & 8.056 & 7.551 \\
\hline $\begin{array}{l}\text { The GCC should } \\
\text { continue to make } \\
\text { decisions in the future. }\end{array}$ & 3.518 & 5.494 & 12.519 & 12.358 \\
\hline
\end{tabular}

Table SI-2.2 Parameter Estimates 
SI-3 Construction of US Sample

\section{United States}

YouGov interviewed 1847 respondents who were then matched down to a sample of 1600 to produce the final dataset. The respondents were matched to a sampling frame on gender, age, race, education, party identification, ideology, and political interest. The frame was constructed by stratified sampling from the full 2010 American Community Survey (ACS) sample with selection within strata by weighted sampling with replacements (using the person weights on the public use file). Data on voter registration status and turnout were matched to this frame using the November 2010 Current Population Survey. Data on interest in politics and party identification were then matched to this frame from the 2007 Pew Religious Life Survey. The matched cases were weighted to the sampling frame using propensity scores. The matched cases and the frame were combined and a logistic regression was estimated for inclusion in the frame. The propensity score function included age, gender, race/ethnicity, years of education, and ideology. The propensity scores were grouped into deciles of the estimated propensity score in the frame and post-stratified according to these deciles. 


\section{SI-4 Main Effects}

Tables SI-4.1 and SI-4.2 detail the bootstrap results discussed in Section 4.1. We calculated ordinal logistic regressions for APPROPRIATE and DEFERENCE and using these estimates, we calculated the difference in $\operatorname{Pr}$ (Agree) and $\operatorname{Pr}$ (Disagree) between treatments and the status quo (Consensus-Legislature) for the full and reduced samples (i.e., participants who answered all comprehension questions correctly by the second attempt). Table S1-4.1 and S1-4.2 are the results for USA and Germany, respectively. We calculated the confidence intervals of these differences using bootstrapping and use the normal distribution to estimate significance. The 5-ITEM model was estimated using OLS. After which, we calculated the difference in means between treatments and the status quo. We used bootstrapping to calculate the standard errors of this difference, and compared to the confidence intervals to a normal distribution.

\begin{tabular}{|l|c|l|l|l|l|l|}
\hline & & \multicolumn{2}{|c|}{ APPROPRIATE } & \multicolumn{2}{c|}{ DEFERENCE } & 5-ITEM \\
\hline & & $\begin{array}{l}\text { Difference } \\
\text { Pr(Agree) }\end{array}$ & $\begin{array}{l}\text { Difference } \\
\text { Pr(Disagree) }\end{array}$ & $\begin{array}{l}\text { Difference } \\
\text { Pr(Agree) }\end{array}$ & $\begin{array}{l}\text { Difference } \\
\text { Pr(Disagree) }\end{array}$ & $\begin{array}{l}\text { Mean } \\
\text { Difference }\end{array}$ \\
\hline ConLeg- & Full & $(-0.14,0.05)$ & $(-0.02,0.05)$ & $(-0.15,0.03)$ & $(-0.01,0.07)$ & $(-0.31,0.06)$ \\
MajAuto & Reduced & $(-0.13,0.04)$ & $(-0.02,0.05)$ & $(-0.14,0.04)$ & $(-0.02,0.07)$ & $(-0.31,0.05)$ \\
\hline ConLeg- & Full & $(-0.11,0.07)$ & $(-0.01,0.05)$ & $(-0.11,0.03)$ & $(-0.02,0.05)$ & $(-0.25,0.11)$ \\
MajLeg & Reduced & $(-0.11,0.05)$ & $(-0.02,0.05)$ & $(-0.11,0.04)$ & $(-0.02,0.06)$ & $(-0.23,0.14)$ \\
\hline ConLeg- & Full & $(-0.05,0.09)$ & $(-0.06,0.02)$ & $(-0.08,0.06)$ & $(-0.04,0.04)$ & $(-0.11,0.24)$ \\
ConAuto & Reduced & $(-0.07,0.09)$ & $(-0.06,0.03)$ & $(-0.08,0.08)$ & $(-0.06,0.04)$ & $(-0.15,0.24)$ \\
\hline
\end{tabular}

Table SI-4.1: Bootstrap results for USA, 1000 replications, 95 percent confidence intervals compared to a normal distribution

\begin{tabular}{|l|l|l|l|l|l|l|}
\hline & & \multicolumn{2}{|c|}{ APPROPRIATE } & \multicolumn{2}{c|}{ DEFERENCE } & 5-ITEM \\
\hline & & $\begin{array}{l}\text { Difference } \\
\text { Pr(Agree) }\end{array}$ & $\begin{array}{l}\text { Difference } \\
\text { Pr(Disagree) }\end{array}$ & $\begin{array}{l}\text { Difference } \\
\text { Pr(Agree) }\end{array}$ & $\begin{array}{l}\text { Difference } \\
\text { Pr(Disagree) }\end{array}$ & $\begin{array}{l}\text { Mean } \\
\text { Difference }\end{array}$ \\
\hline ConLeg- & Full & $(-0.09,0.04)$ & $(-0.01,0.03)$ & $(-0.04,0.09)$ & $(-0.02,0.01)$ & $(-0.09,0.14)$ \\
MajAuto & Reduced & $(-0.09,0.05)$ & $(-0.01,0.03)$ & $(-0.03,0.11)$ & $(-0.03,0.01)$ & $(-0.08,0.17)$ \\
\hline ConLeg- & Full & $(-0.03,0.07)$ & $(-0.02,0.01)$ & $(-0.02,0.09)$ & $(-0.02,0.01)$ & $(-0.10,0.12)$ \\
MajLeg & Reduced & $(-0.02,0.10)$ & $(-0.03,0.01)$ & $(-0.01,0.12)$ & $(-0.03,0.00)$ & $(-0.06,0.18)$ \\
\hline ConLeg- & Full & $(-0.12,0.00)$ & $(-0.00,0.04)$ & $(-0.08,0.05)$ & $(-0.01,0.02)$ & $(-0.16,0.07)$ \\
ConAuto & Reduced & $(-0.13,0.01)$ & $(-0.00,0.04)$ & $(-0.09,0.06)$ & $(-0.01,0.02)$ & $(-0.16,0.08)$ \\
\hline
\end{tabular}

Table SI-4.2: Bootstrap results for Germany, 1000 replications, 95 percent confidence intervals compared to a normal distribution 


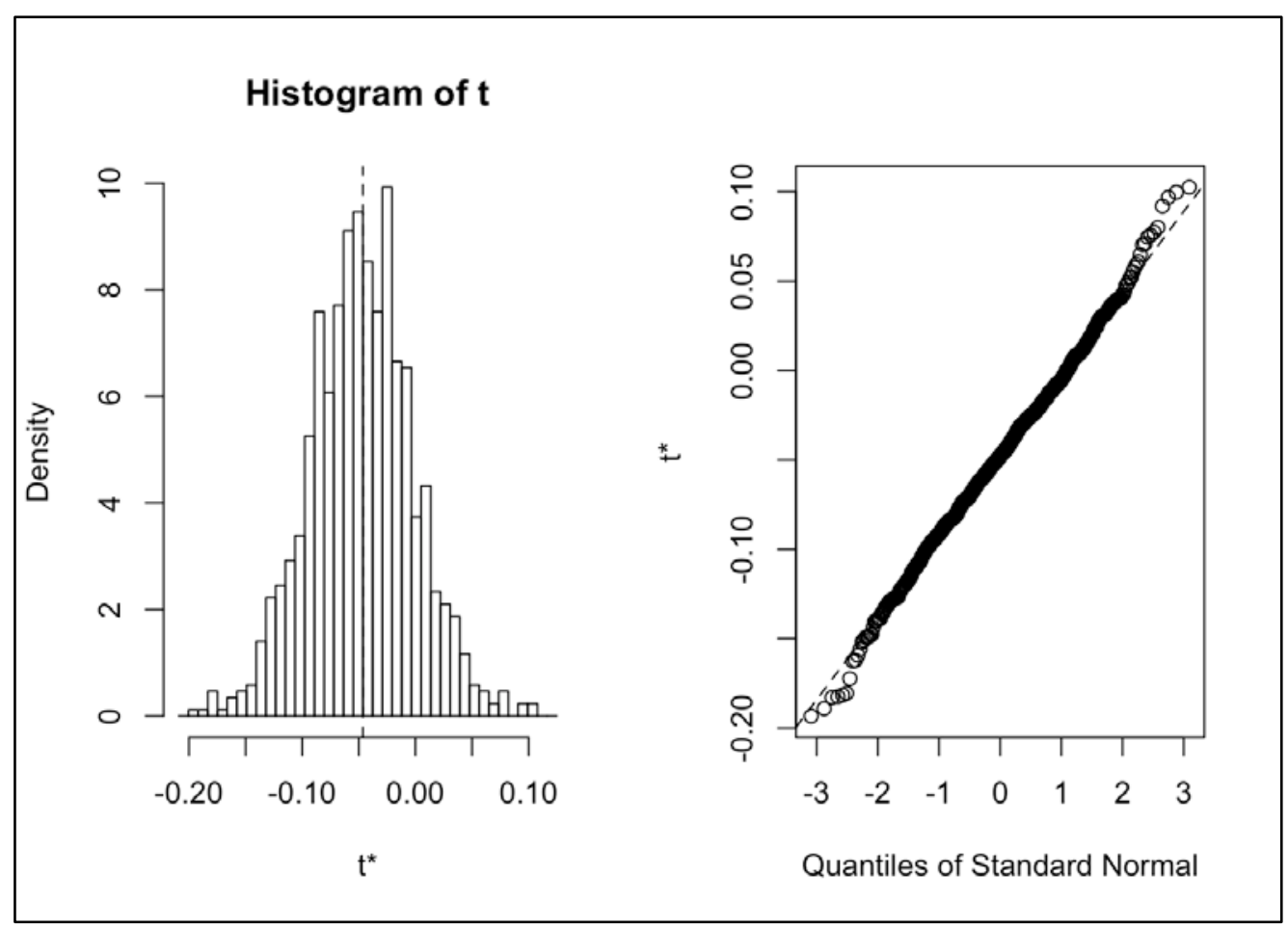

Figure SI-4.1 United States Full Sample: The left side is the distributions of differences in the probability of agree with APPROPRIATENESS between Consensus-Legislature and MajorityAutomatic. The right side is a QQplot comparing the standard errors to the quantiles of a normal distribution.

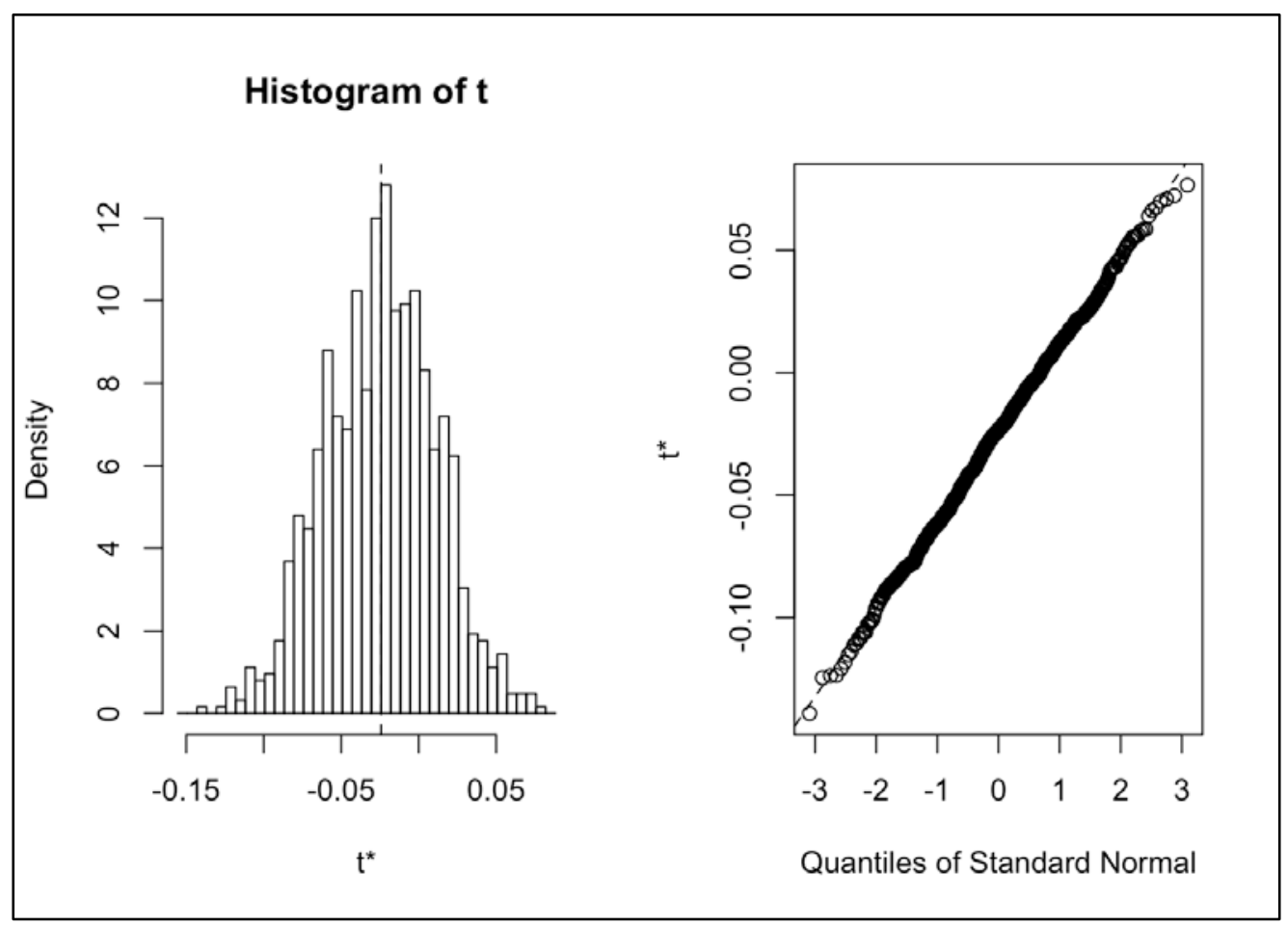

Figure SI-4.2 Germany Full Sample: The left side is the distributions of differences in the probability of agree with APPROPRIATENESS between Consensus-Legislature and MajorityAutomatic. The right side is a QQplot comparing the standard errors to the quantiles of a normal distribution. 
SI-4 (a) Moderating Effects: Cognitive Mobilization

\begin{tabular}{|l|c|l|l|l|l|l|}
\hline & & \multicolumn{2}{|c|}{ APPROPRATE } & \multicolumn{2}{c|}{ DEFERENCE } & \multicolumn{1}{c|}{ 5-ITEM } \\
\hline & & $\begin{array}{l}\text { Difference } \\
\text { Pr(Agree) }\end{array}$ & $\begin{array}{l}\text { Difference } \\
\text { Pr(Disagree) }\end{array}$ & $\begin{array}{l}\text { Difference } \\
\text { Pr(Agree) }\end{array}$ & $\begin{array}{l}\text { Difference } \\
\text { Pr(Disagree) }\end{array}$ & $\begin{array}{l}\text { Mean } \\
\text { Difference }\end{array}$ \\
\hline ConLeg- & Full & $(-0.59,0.03)$ & $(-0.06,0.21)$ & $\mathbf{( - 0 . 7 0 , - 0 . 1 3 )}$ & $\mathbf{( 0 . 0 0 2 , ~ 0 . 3 3 )}$ & $\mathbf{( - 1 . 2 9 , - 0 . 0 7 )}$ \\
MajAuto & Reduced & $(-0.62,0.04)$ & $(-0.06,0.25)$ & $\mathbf{( - 0 . 7 0 , - 0 . 1 0 )}$ & $\mathbf{( 0 . 0 3 , 0 . 3 9 )}$ & $\mathbf{( - 1 . 3 1 , - 0 . 0 3 )}$ \\
\hline ConLeg- & Full & $(-0.31,0.28)$ & $(-0.15,0.16)$ & $(-0.37,0.14)$ & $(-0.11,0.26)$ & $(-0.82,0.36)$ \\
MajLeg & Reduced & $(-0.25,0.31)$ & $(-0.22,0.17)$ & $(-0.30,0.16)$ & $(-0.14,0.28)$ & $(-0.74,0.50)$ \\
\hline ConLeg- & Full & $(-0.32,0.29)$ & $(-0.16,0.16)$ & $(-0.36,0.19)$ & $(-0.14,0.27)$ & $(-0.70,0.46)$ \\
ConAuto & Reduced & $(-0.31,0.33)$ & $(-0.20,0.21)$ & $(-0.26,0.24)$ & $(-0.23,0.27)$ & $(-0.66,0.59)$ \\
\hline
\end{tabular}

Table SI-4.1: Bootstrap results for participants who are extremely interested in international politics from the USA, 1000 replications, 95 percent confidence intervals compared to a normal distribution

\begin{tabular}{|l|c|c|c|l|l|l|}
\hline & & \multicolumn{2}{|c|}{ APPROPRIATE } & \multicolumn{2}{c|}{ DEFERENCE } & \multicolumn{1}{c|}{ 5-ITEM } \\
\hline & & $\begin{array}{l}\text { Difference } \\
\text { Pr(Agree) }\end{array}$ & $\begin{array}{l}\text { Difference } \\
\text { Pr(Disagree) }\end{array}$ & $\begin{array}{l}\text { Difference } \\
\text { Pr(Agree) }\end{array}$ & $\begin{array}{l}\text { Difference } \\
\text { Pr(Disagree) }\end{array}$ & $\begin{array}{l}\text { Mean } \\
\text { Difference }\end{array}$ \\
\hline ConLeg- & Full & $(-0.21,0.17)$ & $(-0.08,0.09)$ & $(-0.16,0.20)$ & $(-0.10,0.08)$ & $(-0.37,0.50)$ \\
MajAuto & Reduced & $(-0.21,0.19)$ & $(-0.08,0.09)$ & $(-0.16,0.26)$ & $(-0.10,0.08)$ & $(-0.27,0.57)$ \\
\hline ConLeg- & Full & $(-0.16,0.21)$ & $(-0.11,0.08)$ & $(-0.16,0.21)$ & $(-0.11,0.07)$ & $(-0.40,0.48)$ \\
MajLeg & Reduced & $(-0.15,0.24)$ & $(-0.12,0.08)$ & $(-0.15,0.24)$ & $(-0.15,0.06)$ & $(-0.35,0.64)$ \\
\hline ConLeg- & Full & $(-0.11,0.21)$ & $(-0.11,0.05)$ & $(-0.15,0.20)$ & $(-0.10,0.07)$ & $(-0.23,0.53)$ \\
ConAuto & Reduced & $(-0.15,0.24)$ & $(-0.12,0.07)$ & $(-0.14,0.29)$ & $(-0.16,0.07)$ & $(-0.15,0.70)$ \\
\hline
\end{tabular}

Table SI-4.2: Bootstrap results for participants who are not at all interested in international politics from the USA, 1000 replications, 95 percent confidence intervals compared to a normal distribution

\begin{tabular}{|l|c|l|l|l|l|l|}
\hline & & \multicolumn{2}{|c|}{ APPROPRIATE } & \multicolumn{2}{c|}{ DEFERENCE } & 5-ITEM \\
\hline & & $\begin{array}{l}\text { Difference } \\
\text { Pr(Agree) }\end{array}$ & $\begin{array}{l}\text { Difference } \\
\text { Pr(Disagree) }\end{array}$ & $\begin{array}{l}\text { Difference } \\
\text { Pr(Agree) }\end{array}$ & $\begin{array}{l}\text { Difference } \\
\text { Pr(Disagree) }\end{array}$ & $\begin{array}{l}\text { Mean } \\
\text { Difference }\end{array}$ \\
\hline ConLeg- & Full & $(-0.51,0.05)$ & $(-0.03,0.15)$ & $(-0.38,0.19)$ & $(-0.05,0.09)$ & $(-0.60,0.44)$ \\
MajAuto & Reduced & $(-0.53,0.11)$ & $(-0.04,0.16)$ & $(-0.42,0.21)$ & $(-0.05,0.09)$ & $(-0.69,0.45)$ \\
\hline ConLeg- & Full & $(-0.46,0.12)$ & $(-0.04,0.14)$ & $(-0.27,0.25)$ & $(-0.06,0.07)$ & $(-0.53,0.45)$ \\
MajLeg & Reduced & $(-0.48,0.16)$ & $(-0.06,0.15)$ & $(-0.21,0.35)$ & $(-0.09,0.05)$ & $(-0.47,0.60)$ \\
\hline ConLeg- & Full & $(-0.30,0.24)$ & $(-0.10,0.12)$ & $(-0.45,0.13)$ & $(-0.04,0.10)$ & $(-0.52,0.52)$ \\
ConAuto & Reduced & $(-0.30,0.34)$ & $(-0.13,0.12)$ & $(-0.42,0.20$ & $(-0.05,0.09)$ & $(-0.49,0.54)$ \\
\hline
\end{tabular}

Table SI-4.3: Bootstrap results for participants who are extremely interested in international politics from Germany, 1000 replications, 95 percent confidence intervals compared to a normal distribution

\begin{tabular}{|l|c|l|l|l|l|l|}
\hline & & \multicolumn{2}{|c|}{ APPROPRIATE } & \multicolumn{2}{c|}{ DEFERENCE } & \multicolumn{1}{c|}{ 5-ITEM } \\
\hline & & $\begin{array}{l}\text { Difference } \\
\text { Pr(Agree) }\end{array}$ & $\begin{array}{l}\text { Difference } \\
\text { Pr(Disagree) }\end{array}$ & $\begin{array}{l}\text { Difference } \\
\text { Pr(Agree) }\end{array}$ & $\begin{array}{l}\text { Difference } \\
\text { Pr(Disagree) }\end{array}$ & $\begin{array}{l}\text { Mean } \\
\text { Difference }\end{array}$ \\
\hline ConLeg- & Full & $(-0.43,0.48)$ & $(-0.24,0.22)$ & $(-0.05,0.78)$ & $(-0.26,0.10)$ & $(-0.23,1.57)$ \\
MajAuto & Reduced & $(-0.41,0.57)$ & $(-0.25,0.22)$ & $(-0.12,0.77)$ & $(-0.22,0.13)$ & $(-0.26,1.66)$ \\
\hline ConLeg- & Full & $(-0.58,0.31)$ & $(-0.15,0.22)$ & $(-0.22,0.54)$ & $(-0.13,0.07)$ & $(-0.53,0.45)$ \\
MajLeg & Reduced & $(-0.64,0.33)$ & $(-0.13,0.19)$ & $(-0.17,0.57)$ & $(-0.12,0.06)$ & $(-0.47,0.60)$ \\
\hline ConLeg- & Full & $(-0.38,0.46)$ & $(-0.24,0.21)$ & $(-0.43,0.36)$ & $(-0.08,0.09)$ & $(-0.60,1.15)$ \\
ConAuto & Reduced & $(-0.42,0.57)$ & $(-0.24,0.21)$ & $(-0.36,0.33)$ & $(-0.06,0.07)$ & $(-0.59,1.26)$ \\
\hline
\end{tabular}

Table SI-4.4: Bootstrap results for participants who are not at all interested in international politics from Germany, 1000 replications, 95 percent confidence intervals compared to a normal distribution 
SI - 4 (b) Alternative measures of cognitively mobilization: Education

Education is a frequently used as a measure of cognitive mobilization. The German and American education systems differ substantially. Therefore, YouGov uses different questions in each country. For the American sample, we used: What is the highest level of education you have completed? (Did not graduate from high school, High school graduate, Some college, but no degree (yet), 2-year college degree, 4-year college degree, Postgraduate degree (MA, MBA, MD, JD, PhD, etc.)) . For the German sample, we used: When did you stop schooling? (15 or younger, 16, 17-18, 19, 20 or older, still studying, I can't remember). 


\begin{tabular}{|c|c|c|c|c|c|c|}
\hline & \multicolumn{2}{|c|}{ APPROPRIATE } & \multicolumn{2}{|c|}{ DEFERENCE } & \multicolumn{2}{|c|}{ 5-ITEM } \\
\hline & Full & Reduced & Full & Reduced & Full & Reduced \\
\hline Majority & $\begin{array}{c}0.09 \\
0.211\end{array}$ & $\begin{array}{ll}0.11 \\
0.23)\end{array}$ & $\begin{array}{c}-0.01 \\
-0.01\end{array}$ & $\begin{array}{ll}0.07 \\
0.07)\end{array}$ & $\begin{array}{ll}0.06 \\
0.089\end{array}$ & $\begin{array}{ll}0.10 \\
0.144\end{array}$ \\
\hline Automatic & $-0.44 *$ & $\begin{array}{l}(0.25) \\
-0.37\end{array}$ & $-0.47 *$ & $\begin{array}{l}(0.22) \\
-0.38\end{array}$ & $-0.26 *$ & $\begin{array}{l}(0.14) \\
-0.19\end{array}$ \\
\hline & (0.20) & $(0.23)$ & $(0.20)$ & $(0.23)$ & (0.12) & $(0.14)$ \\
\hline No high school & $\begin{array}{c}-0.34 \\
-0.43)\end{array}$ & $\begin{array}{l}-0.53 \\
-0.48)\end{array}$ & -0.17 & $\begin{array}{l}-0.29 \\
(0.49)\end{array}$ & $\begin{array}{r}-0.15 \\
(0.12)\end{array}$ & $\begin{array}{r}-0.15 \\
-0.311\end{array}$ \\
\hline $\begin{array}{c}\text { Some college (no } \\
\text { degree) }\end{array}$ & $\begin{array}{c}0.02 \\
(0.25)\end{array}$ & $\begin{array}{c}0.06 \\
(0.28)\end{array}$ & $\begin{array}{l}-0.17 \\
(0.25)\end{array}$ & $\begin{array}{l}-0.06 \\
(0.28)\end{array}$ & $\begin{array}{l}-0.07 \\
(0.26)\end{array}$ & $\begin{array}{c}0.00 \\
(0.17)\end{array}$ \\
\hline 2-year college & $\begin{array}{l}-0.05 \\
(0.33)\end{array}$ & $\begin{array}{c}0.07 \\
(0.39)\end{array}$ & $\begin{array}{l}-0.20 \\
(0.33)\end{array}$ & $\begin{array}{l}-0.13 \\
(0.38)\end{array}$ & $\begin{array}{l}-0.07 \\
(0.14)\end{array}$ & $\begin{array}{c}0.01 \\
(0.23)\end{array}$ \\
\hline 4-year college & 0.30 & 0.29 & -0.03 & 0.02 & 0.20 & 0.22 \\
\hline & $(0.26)$ & $(0.30)$ & $(0.26)$ & $(0.29)$ & $(0.19)$ & $(0.17)$ \\
\hline Postgraduate & 0.32 & 0.29 & $\begin{array}{l}-0.25 \\
(0.36)\end{array}$ & -0.05 & 0.08 & 0.11 \\
\hline Majority*Auto & 0.50 & 0.28 & 0.46 & 0.28 & $\begin{array}{c}(0.15) \\
0.22\end{array}$ & $\begin{array}{l}(0.24) \\
0.05\end{array}$ \\
\hline & $(0.29)$ & $(0.32)$ & $(0.29)$ & $(0.32)$ & $(0.21)$ & $(0.19)$ \\
\hline $\begin{array}{c}\text { No high } \\
\text { school*Majority }\end{array}$ & $\begin{array}{l}1.33 \\
(0.70)\end{array}$ & $\begin{array}{l}1.25 \\
(0.79)\end{array}$ & $\begin{array}{c}0.49 \\
(0.66)\end{array}$ & $\begin{array}{c}0.71 \\
(0.78)\end{array}$ & $\begin{array}{c}0.37 \\
(0.39)\end{array}$ & $\begin{array}{c}0.41 \\
(0.47)\end{array}$ \\
\hline $\begin{array}{l}\text { Some college (no } \\
\text { degree) *Majority }\end{array}$ & $\begin{array}{c}-0.15 \\
(0.35)\end{array}$ & $\begin{array}{l}-0.33 \\
(0.39)\end{array}$ & $\begin{array}{c}0.08 \\
(0.35)\end{array}$ & $\begin{array}{l}-0.21 \\
(0.39)\end{array}$ & $\begin{array}{c}0.02 \\
(0.20)\end{array}$ & $\begin{array}{l}-0.16 \\
(0.23)\end{array}$ \\
\hline 2-year college*Majority & $\begin{array}{c}0.15 \\
(0.47)\end{array}$ & $\begin{array}{c}0.00 \\
(0.55)\end{array}$ & $\begin{array}{c}0.24 \\
(0.47)\end{array}$ & $\begin{array}{c}0.10 \\
(0.53)\end{array}$ & $\begin{array}{c}0.07 \\
(0.27)\end{array}$ & $\begin{array}{l}-0.08 \\
(0.31)\end{array}$ \\
\hline 4-year college*Majority & $\begin{array}{c}-0.02 \\
(0.38)\end{array}$ & $\begin{array}{l}-0.08 \\
(0.42)\end{array}$ & $\begin{array}{c}0.32 \\
(0.38)\end{array}$ & $\begin{array}{c}0.09 \\
(0.42)\end{array}$ & $\begin{array}{l}-0.02 \\
(0.22)\end{array}$ & $\begin{array}{c}-0.08 \\
(0.31)\end{array}$ \\
\hline Postgraduate*Majority & -0.17 & -0.51 & $\begin{array}{l}0.24 \\
(0.49)\end{array}$ & -0.18 & $\begin{array}{l}-0.05 \\
(0.28)\end{array}$ & -0.09 \\
\hline $\begin{array}{c}\text { No high } \\
\text { school*Automatic }\end{array}$ & $\begin{array}{c}0.64 \\
(0.62)\end{array}$ & $\begin{array}{c}0.81 \\
(0.69)\end{array}$ & $\begin{array}{c}0.76 \\
(0.64)\end{array}$ & $\begin{array}{c}0.76 \\
(0.71)\end{array}$ & $\begin{array}{c}0.33 \\
(0.37)\end{array}$ & $\begin{array}{c}0.22 \\
(0.32)\end{array}$ \\
\hline $\begin{array}{l}\text { Some college (no } \\
\text { degree) *Automatic }\end{array}$ & $\begin{array}{l}0.72 * \\
(0.35)\end{array}$ & $\begin{array}{c}0.73 \\
(0.40)\end{array}$ & $\begin{array}{l}\mathbf{0 . 8 8} * \\
(0.35)\end{array}$ & $\begin{array}{l}0.85 * \\
(0.40)\end{array}$ & $\begin{array}{l}0.54 * \\
(0.20)\end{array}$ & $\begin{array}{l}0.24 * \\
(0.43)\end{array}$ \\
\hline $\begin{array}{l}\text { 2-year college } \\
\text { *Automatic }\end{array}$ & $\begin{array}{c}0.83 \\
(0.50)\end{array}$ & $\begin{array}{c}0.67 \\
(0.57)\end{array}$ & $\begin{array}{c}0.78 \\
(0.50)\end{array}$ & $\begin{array}{c}0.53 \\
(0.56)\end{array}$ & $\begin{array}{c}0.41 \\
(0.29)\end{array}$ & $\begin{array}{c}0.51 \\
(0.23)\end{array}$ \\
\hline $\begin{array}{c}\text { 4-year } \\
\text { college*Automatic }\end{array}$ & $\begin{array}{c}0.25 \\
(0.39)\end{array}$ & $\begin{array}{c}0.09 \\
(0.43)\end{array}$ & $\begin{array}{c}0.39 \\
(0.38)\end{array}$ & $\begin{array}{c}0.16 \\
(0.42)\end{array}$ & $\begin{array}{c}0.11 \\
(0.22)\end{array}$ & $\begin{array}{c}-0.02 \\
(0.25)\end{array}$ \\
\hline Postgraduate*Automatic & $\begin{array}{c}0.42 \\
(0.50)\end{array}$ & $\begin{array}{c}0.35 \\
(0.55)\end{array}$ & $\begin{array}{l}1.24 * \\
(0.49)\end{array}$ & $\begin{array}{c}0.85 \\
(0.54)\end{array}$ & $\begin{array}{c}0.44 \\
(0.28)\end{array}$ & $\begin{array}{c}0.30 \\
(0.33)\end{array}$ \\
\hline $\begin{array}{c}\text { No high } \\
\text { school*Maj*Auto }\end{array}$ & $\begin{array}{l}-1.47 \\
(0.92)\end{array}$ & $\begin{array}{c}-0.90 \\
(1.06)\end{array}$ & $\begin{array}{l}-0.95 \\
(0.90)\end{array}$ & $\begin{array}{c}-0.60 \\
(1.05)\end{array}$ & $\begin{array}{l}-0.39 \\
(0.53)\end{array}$ & $\begin{array}{c}0.00 \\
(0.63)\end{array}$ \\
\hline $\begin{array}{l}\text { Some college (no } \\
\text { degree) *Maj*Auto }\end{array}$ & $\begin{array}{c}-0.19 \\
(0.50)\end{array}$ & $\begin{array}{c}-0.12 \\
(0.57)\end{array}$ & $\begin{array}{c}-0.43 \\
(0.50)\end{array}$ & $\begin{array}{l}-0.36 \\
(0.56)\end{array}$ & $\begin{array}{l}-0.20 \\
(0.29)\end{array}$ & $\begin{array}{l}-0.07 \\
(0.33)\end{array}$ \\
\hline $\begin{array}{c}\text { 2-year } \\
\text { college*Maj*Auto }\end{array}$ & $\begin{array}{l}-1.16 \\
(0.69)\end{array}$ & $\begin{array}{l}-0.60 \\
(0.80)\end{array}$ & $\begin{array}{l}-1.12 \\
(0.68)\end{array}$ & $\begin{array}{c}-0.74 \\
(0.77)\end{array}$ & $\begin{array}{l}-0.54 \\
(0.39)\end{array}$ & $\begin{array}{c}-0.22 \\
(0.46)\end{array}$ \\
\hline $\begin{array}{c}\text { 4-year } \\
\text { college*Maj*Auto }\end{array}$ & $\begin{array}{l}-0.83 \\
(0.55)\end{array}$ & $\begin{array}{l}-0.28 \\
(0.61)\end{array}$ & $\begin{array}{c}-0.81 \\
(0.55)\end{array}$ & $\begin{array}{c}-0.29 \\
(0.61)\end{array}$ & $\begin{array}{l}-0.35 \\
(0.31)\end{array}$ & $\begin{array}{c}0.00 \\
(0.36)\end{array}$ \\
\hline Postgraduate*Maj*Auto & $\begin{array}{l}-0.31 \\
(0.69)\end{array}$ & $\begin{array}{c}0.11 \\
(0.75)\end{array}$ & $\begin{array}{c}-1.09 \\
(0.68)\end{array}$ & $\begin{array}{l}-0.47 \\
(0.75)\end{array}$ & $\begin{array}{c}-0.29 \\
(0.38)\end{array}$ & $\begin{array}{c}0.02 \\
(0.43)\end{array}$ \\
\hline $\mathbf{N}$ & 1600 & 1270 & 1600 & 1270 & 1600 & 1600 \\
\hline Link & logit & logit & logit & logit & & \\
\hline AIC & 3945.24 & 3173.38 & 4026.18 & 3225.72 & 4757.114 & 3845.425 \\
\hline
\end{tabular}

Table SI -4.5 ${ }^{* * *} \mathrm{p}<0.001,{ }^{* *} \mathrm{p}<0.01,{ }^{*} \mathrm{p}<0.05$. We use an ordinal logistic regression to calculate the interaction effects between education and treatments variables on APPROPRIATE and DEFERENCE. The coefficients cannot be interpreted directly. We use an OLS to calculate the results for the 5-ITEM variable. This is why there is a link function for APPROPRIATE and DEFERENCE and not for the 5-ITEM. 
SI-4 (c) Moderating Effects: Climate Concern

\begin{tabular}{|l|c|l|l|l|l|l|}
\hline & & \multicolumn{2}{|c|}{ APPROPRIATE } & \multicolumn{2}{c|}{ DEFERENCE } & 5-ITEM \\
\hline & & $\begin{array}{l}\text { Difference } \\
\text { Pr(Agree) }\end{array}$ & $\begin{array}{l}\text { Difference } \\
\text { Pr(Disagree) }\end{array}$ & $\begin{array}{l}\text { Difference } \\
\text { Pr(Agree) }\end{array}$ & $\begin{array}{l}\text { Difference } \\
\text { Pr(Disagree) }\end{array}$ & $\begin{array}{l}\text { Mean } \\
\text { Difference }\end{array}$ \\
\hline ConLeg- & Full & $(-0.08,0.11)$ & $(0.00,0.00)$ & $(-0.13,0.08)$ & $(-0.00,0.01)$ & $(-0.25,0.12)$ \\
MajAuto & Reduced & $(-0.09,0.09)$ & $(0.00,0.00)$ & $(-0.13,0.09)$ & $(0.00,0.01)$ & $(-0.29,0.10)$ \\
\hline ConLeg- & Full & $(-0.15,0.03)$ & $(0.00,0.01)$ & $(-0.17,0.04)$ & $(0.00,0.01)$ & $(-0.35,0.03)$ \\
MajLeg & Reduced & $(-0.13,0.04)$ & $(0.00,0.00)$ & $(-0.16,0.06)$ & $(0.00,0.01)$ & $(-0.34,0.07)$ \\
\hline ConLeg- & Full & $(-0.08,0.11)$ & $(0.00,0.00)$ & $(-0.13,0.08)$ & $(0.00,0.01)$ & $(-0.15,0.21)$ \\
ConAuto & Reduced & $(-0.09,0.09)$ & $(0.00,0.00)$ & $(-0.13,0.09)$ & $(0.00,0.00)$ & $(-0.15,0.21)$ \\
\hline
\end{tabular}

Table SI-4.6: Bootstrap results for participants who are extremely concerned about climate change (12) from the USA, 1000 replications, 95 percent confidence intervals compared to a normal distribution

\begin{tabular}{|l|c|c|c|c|c|c|}
\hline & & \multicolumn{2}{|c|}{ APPROPRIATE } & \multicolumn{2}{c|}{ DEFERENCE } & 5-ITEM \\
\hline & & $\begin{array}{l}\text { Difference } \\
\text { Pr(Agree) }\end{array}$ & $\begin{array}{l}\text { Difference } \\
\text { Pr(Disagree) }\end{array}$ & $\begin{array}{l}\text { Difference } \\
\text { Pr(Agree) }\end{array}$ & $\begin{array}{l}\text { Difference } \\
\text { Pr(Disagree) }\end{array}$ & $\begin{array}{l}\text { Mean } \\
\text { Difference }\end{array}$ \\
\hline ConLeg- & Full & $(0.00,0.01)$ & $(-0.23,0.14)$ & $(-0.01,0.01)$ & $(-0.28,0.04)$ & $(-0.25,0.32)$ \\
MajAuto & Reduced & $(0.00,0.01)$ & $(-0.18,0.18)$ & $(0.00,0.01)$ & $(-0.30,0.01)$ & $(-0.24,0.24)$ \\
\hline ConLeg- & Full & $(0.00,0.01)$ & $(-0.30,0.02)$ & $(0.00,0.01)$ & $(-0.23,0.06)$ & $(-0.13,0.36)$ \\
MajLeg & Reduced & $(0.00,0.01)$ & $(-0.28,0.01)$ & $(0.00,0.01)$ & $(-0.24,0.05)$ & $(-0.09,0.31)$ \\
\hline ConLeg- & Full & $(0.00,0.01)$ & $(-0.26,0.06)$ & $(0.00,0.01)$ & $(-0.20,0.10)$ & $(-0.13,0.31)$ \\
ConAuto & Reduced & $(0.00,0.01)$ & $(-0.22,0.08)$ & $(0.00,0.01)$ & $(-0.22,0.09)$ & $(-0.17,0.21)$ \\
\hline
\end{tabular}

Table SI-4.7: Bootstrap results for participants who are not at all concerned about climate change (3) from the USA, 1000 replications, 95 percent confidence intervals compared to a normal distribution

\begin{tabular}{|l|c|l|l|l|l|c|}
\hline & & \multicolumn{2}{|c|}{ APPROPRATE } & \multicolumn{2}{c|}{ DEFERENCE } & 5-ITEM \\
\hline & & $\begin{array}{l}\text { Difference } \\
\text { Pr(Agree) }\end{array}$ & $\begin{array}{l}\text { Difference } \\
\text { Pr(Disagree) }\end{array}$ & $\begin{array}{l}\text { Difference } \\
\text { Pr(Agree) }\end{array}$ & $\begin{array}{l}\text { Difference } \\
\text { Pr(Disagree) }\end{array}$ & $\begin{array}{l}\text { Mean } \\
\text { Difference }\end{array}$ \\
\hline ConLeg- & Full & $(-0.14,0.01)$ & $(0.00,0.01)$ & $(-0.12,0.08)$ & $(0.00,0.01)$ & $(-0.32,0.03)$ \\
MajAuto & Reduced & $(-0.19,0.08)$ & $(0.00,0.01)$ & $(-0.15,0.06)$ & $(0.00,0.01)$ & $\mathbf{( - 0 . 3 8 , - 0 . 0 1 )}$ \\
\hline ConLeg- & Full & $(-0.05,0.19)$ & $(-0.01,0.00)$ & $(0.05,0.18)$ & $(0.00,0.01)$ & $(-0.12,0.24)$ \\
MajLeg & Reduced & $(-0.05,0.22)$ & $(-0.01,0.00)$ & $(-0.06,0.18)$ & $(0.00,0.00)$ & $(-0.13,0.25)$ \\
\hline ConLeg- & Full & $(-0.14,0.10)$ & $(-0.01,0.01)$ & $(-0.12,0.08)$ & $(0.00,0.01)$ & $(-0.21,0.14)$ \\
ConAuto & Reduced & $(-0.19,0.08)$ & $(0.00,0.01)$ & $(-0.15,0.06)$ & $(0.00,0.00)$ & $(-0.27,0.08)$ \\
\hline
\end{tabular}

Table SI-4.8: Bootstrap results for participants who are extremely concerned about climate change (12) from Germany, 1000 replications, 95 percent confidence intervals compared to a normal distribution 


\begin{tabular}{|l|c|l|l|l|l|l|}
\hline & & \multicolumn{2}{|c|}{ APPROPRIATE } & \multicolumn{2}{c|}{ DEFERENCE } & 5-ITEM \\
\hline & & $\begin{array}{l}\text { Difference } \\
\text { Pr(Agree) }\end{array}$ & $\begin{array}{l}\text { Difference } \\
\text { Pr(Disagree) }\end{array}$ & $\begin{array}{l}\text { Difference } \\
\text { Pr(Agree) }\end{array}$ & $\begin{array}{l}\text { Difference } \\
\text { Pr(Disagree) }\end{array}$ & $\begin{array}{l}\text { Mean } \\
\text { Difference }\end{array}$ \\
\hline ConLeg- & Full & $(-0.11,0.10)$ & $(-0.59,0.09)$ & $(-0.14,0.17)$ & $\mathbf{( - 0 . 8 6 , - 0 . 1 8 )}$ & $\mathbf{( 0 . 1 8 , ~ 1 . 4 5 )}$ \\
MajAuto & Reduced & $(-0.06,0.07)$ & $(-0.61,0.15)$ & $(-0.13,0.18)$ & $\mathbf{( - 0 . 9 9 , - 0 . 2 0 )}$ & $\mathbf{( 0 . 1 4 , ~ 1 . 5 6 )}$ \\
\hline ConLeg- & Full & $(-0.07,0.04)$ & $(-0.19,0.65)$ & $(-0.11,0.12)$ & $(-0.50,0.35)$ & $(-0.12,0.23)$ \\
MajLeg & Reduced & $(-0.07,0.05)$ & $(-0.23,0.69)$ & $(-0.16,0.20)$ & $(-0.58,0.34)$ & $(-0.13,0.25)$ \\
\hline ConLeg- & Full & $(-0.11,0.10)$ & $(-0.20,0.69)$ & $(-0.14,0.17)$ & $(-0.53,0.40)$ & $(-0.79,0.87)$ \\
ConAuto & Reduced & $(-0.06,0.07)$ & $(-0.51,0.52)$ & $(-0.130 .11)$ & $(-0.83,0.18)$ & $(-0.41,1.19)$ \\
\hline
\end{tabular}

Table SI-4.9: Bootstrap results for participants who are not at all concerned about climate change (3) from Germany, 1000 replications, 95 percent confidence intervals compared to a normal distribution 
SI-5 (a) Interaction of Authority and Perceived Authority

\begin{tabular}{|c|c|c|c|c|c|c|}
\hline \multirow[b]{3}{*}{ Majority } & \multicolumn{2}{|c|}{ Appropriateness } & \multicolumn{2}{|c|}{ Deference } & \multicolumn{2}{|c|}{ 5-ITEM } \\
\hline & Full & Reduced & Full & Reduced & Full & Reduced \\
\hline & $\begin{array}{c}0.13 \\
(0.76)\end{array}$ & $\begin{array}{l}0.245 \\
(0.83)\end{array}$ & $\begin{array}{l}-0.95 \\
(0.75)\end{array}$ & $\begin{array}{l}-0.96 \\
(0.83)\end{array}$ & $\begin{array}{l}-0.09 \\
(0.35)\end{array}$ & $\begin{array}{l}-0.11 \\
(0.38)\end{array}$ \\
\hline Automatic & $\begin{array}{c}0.78 \\
(0.65)\end{array}$ & $\begin{array}{c}0.87 \\
(0.67)\end{array}$ & $\begin{array}{c}0.10 \\
(0.68)\end{array}$ & $\begin{array}{l}-0.07 \\
(0.71)\end{array}$ & $\begin{array}{c}0.10 \\
(0.31)\end{array}$ & $\begin{array}{c}0.08 \\
(0.32)\end{array}$ \\
\hline USA & $\begin{array}{c}-0.36 \\
(0.606)\end{array}$ & $\begin{array}{l}-0.62 \\
(0.68)\end{array}$ & $\begin{array}{c}-1.77 * * \\
(0.62)\end{array}$ & $\begin{array}{c}-2.03^{* *} \\
(0.70)\end{array}$ & $\begin{array}{c}-0.77 * * \\
(0.29)\end{array}$ & $\begin{array}{c}-0.87 * * \\
(0.31)\end{array}$ \\
\hline Too little control & $\begin{array}{c}1.626^{* *} \\
(0.52)\end{array}$ & $\begin{array}{c}1.50 * * \\
(0.55)\end{array}$ & $\begin{array}{c}0.71 \\
(0.55)\end{array}$ & $\begin{array}{c}0.73 \\
(0.59)\end{array}$ & $\begin{array}{c}0.48 \\
(0.26)\end{array}$ & $\begin{array}{c}0.43 \\
(0.26)\end{array}$ \\
\hline Sufficient control & $\begin{array}{c}1.56 * * \\
(0.52)\end{array}$ & $\begin{array}{c}1.52 * * \\
(0.54)\end{array}$ & $\begin{array}{c}0.85 \\
(0.55)\end{array}$ & $\begin{array}{c}0.88 \\
(0.58)\end{array}$ & $\begin{array}{l}0.52^{*} \\
(0.25)\end{array}$ & $\begin{array}{c}0.49 \\
(0.26)\end{array}$ \\
\hline Too much control & $\begin{array}{l}1.23 * \\
(0.54)\end{array}$ & $\begin{array}{l}1.22^{*} \\
(0.57)\end{array}$ & $\begin{array}{c}1.08 \\
(0.58)\end{array}$ & $\begin{array}{l}1.17 \\
0.61)\end{array}$ & $\begin{array}{l}0.56^{*} \\
0.26)\end{array}$ & $\begin{array}{c}0.56 * \\
(0.27)\end{array}$ \\
\hline Maj*Automatic & $\begin{array}{l}-0.44 \\
(0.96)\end{array}$ & $\begin{array}{l}-0.82 \\
(1.04)\end{array}$ & $\begin{array}{c}0.26 \\
(0.96)\end{array}$ & $\begin{array}{c}0.45 \\
(1.05)\end{array}$ & $\begin{array}{l}-0.03 \\
(0.44)\end{array}$ & $\begin{array}{l}-0.02 \\
(0.47)\end{array}$ \\
\hline Maj*USA & $\begin{array}{c}0.68 \\
(0.90)\end{array}$ & $\begin{array}{c}0.45 \\
(1.00)\end{array}$ & $\begin{array}{c}1.60 \\
(0.89)\end{array}$ & $\begin{array}{c}1.74 \\
(1.00)\end{array}$ & $\begin{array}{c}0.56 \\
(0.41)\end{array}$ & $\begin{array}{c}0.54 \\
(0.45)\end{array}$ \\
\hline Auto*USA & $\begin{array}{l}-0.82 \\
(0.80)\end{array}$ & $\begin{array}{l}-0.47 \\
(0.88)\end{array}$ & $\begin{array}{c}0.09 \\
(0.82)\end{array}$ & $\begin{array}{c}0.79 \\
(0.91)\end{array}$ & $\begin{array}{l}-0.01 \\
(0.37)\end{array}$ & $\begin{array}{c}0.22 \\
(0.40)\end{array}$ \\
\hline Maj*Too little & $\begin{array}{l}-0.17 \\
(0.79)\end{array}$ & $\begin{array}{l}-0.34 \\
(0.86)\end{array}$ & $\begin{array}{c}1.02 \\
(0.78)\end{array}$ & $\begin{array}{c}0.91 \\
(0.87)\end{array}$ & $\begin{array}{c}0.13 \\
(0.37)\end{array}$ & $\begin{array}{c}0.12 \\
(0.40)\end{array}$ \\
\hline Maj*Sufficient & $\begin{array}{l}-0.26 \\
(0.79)\end{array}$ & $\begin{array}{l}-0.45 \\
(0.86)\end{array}$ & $\begin{array}{c}0.63 \\
(0.78)\end{array}$ & $\begin{array}{c}0.61 \\
(0.86)\end{array}$ & $\begin{array}{l}-0.01 \\
(0.37)\end{array}$ & $\begin{array}{c}0.00 \\
(0.39)\end{array}$ \\
\hline Maj*Too much & $\begin{array}{c}0.51 \\
(0.82)\end{array}$ & $\begin{array}{c}0.25 \\
(0.89)\end{array}$ & $\begin{array}{c}1.29 \\
(0.83)\end{array}$ & $\begin{array}{c}1.16 \\
(0.91)\end{array}$ & $\begin{array}{c}0.21 \\
(0.38)\end{array}$ & $\begin{array}{c}0.18 \\
(0.41)\end{array}$ \\
\hline Auto*Too little & $\begin{array}{l}-0.91 \\
(0.68)\end{array}$ & $\begin{array}{l}-0.95 \\
(0.71)\end{array}$ & $\begin{array}{l}-0.05 \\
(0.72)\end{array}$ & $\begin{array}{c}0.07 \\
(0.76)\end{array}$ & $\begin{array}{l}-0.13 \\
(0.32)\end{array}$ & $\begin{array}{l}-0.11 \\
(0.34)\end{array}$ \\
\hline Auto*Sufficient & $\begin{array}{l}-0.31 \\
(0.68)\end{array}$ & $\begin{array}{l}-0.48 \\
(0.70)\end{array}$ & $\begin{array}{c}0.19 \\
(0.71)\end{array}$ & $\begin{array}{c}0.30 \\
(0.75)\end{array}$ & $\begin{array}{c}0.04 \\
(0.32)\end{array}$ & $\begin{array}{c}0.05 \\
(0.33)\end{array}$ \\
\hline Auto*Too much & $\begin{array}{c}-0.46 \\
(0.80)\end{array}$ & $\begin{array}{l}-0.75 \\
(0.85)\end{array}$ & $\begin{array}{c}-0.6 \\
(0.85)\end{array}$ & $\begin{array}{l}-0.54 \\
(0.91)\end{array}$ & $\begin{array}{l}-0.26 \\
(0.38)\end{array}$ & $\begin{array}{l}-0.24 \\
(0.40)\end{array}$ \\
\hline USA*Too little & $\begin{array}{c}-0.62 \\
(0.65)\end{array}$ & $\begin{array}{l}-0.58 \\
(0.74)\end{array}$ & $\begin{array}{c}0.23 \\
(0.67)\end{array}$ & $\begin{array}{c}0.11 \\
(0.75)\end{array}$ & $\begin{array}{c}0.12 \\
(0.31)\end{array}$ & $\begin{array}{c}0.08 \\
(0.34)\end{array}$ \\
\hline USA*Sufficient & $\begin{array}{c}0.52 \\
(0.63)\end{array}$ & $\begin{array}{c}0.73 \\
(0.71)\end{array}$ & $\begin{array}{l}1.30 * \\
(0.65)\end{array}$ & $\begin{array}{l}1.49 * \\
(0.73)\end{array}$ & $\begin{array}{l}0.62 * \\
(0.30)\end{array}$ & $\begin{array}{l}0.70 * \\
(0.33)\end{array}$ \\
\hline
\end{tabular}




\begin{tabular}{|c|c|c|c|c|c|c|}
\hline USA*Too much & $\begin{array}{l}1.01 \\
(0.68)\end{array}$ & $\begin{array}{l}1.26 \\
(0.75)\end{array}$ & $\begin{array}{c}1.21 \\
(0.70)\end{array}$ & $\begin{array}{c}1.33 \\
(0.77)\end{array}$ & $\begin{array}{c}0.59 \\
(0.32)\end{array}$ & $\begin{array}{c}0.67 \\
(0.34)\end{array}$ \\
\hline Maj*Auto*USA & $\begin{array}{l}-0.33 \\
(1.15)\end{array}$ & $\begin{array}{l}-0.03782 \\
(1.27)\end{array}$ & $\begin{array}{l}-1.19 \\
(1.14)\end{array}$ & $\begin{array}{l}-1.91 \\
(1.28)\end{array}$ & $\begin{array}{l}-0.41 \\
(0.52)\end{array}$ & $\begin{array}{l}-0.53 \\
(0.57)\end{array}$ \\
\hline $\begin{array}{l}\text { Maj * Auto * } \\
\text { Too little }\end{array}$ & $\begin{array}{c}0.74 \\
(1.01)\end{array}$ & $\begin{array}{l}1.27 \\
(1.09)\end{array}$ & $\begin{array}{l}-0.34 \\
(1.00)\end{array}$ & $\begin{array}{l}-0.36 \\
(1.10)\end{array}$ & $\begin{array}{c}0.04 \\
(0.46)\end{array}$ & $\begin{array}{c}0.11 \\
(0.50)\end{array}$ \\
\hline $\begin{array}{l}\text { Maj * Auto * } \\
\text { Sufficient }\end{array}$ & $\begin{array}{c}0.21 \\
(1.00)\end{array}$ & $\begin{array}{c}0.63 \\
(1.08)\end{array}$ & $\begin{array}{l}-0.20 \\
(1.00)\end{array}$ & $\begin{array}{l}-0.36 \\
(1.09)\end{array}$ & $\begin{array}{c}0.03 \\
(0.46)\end{array}$ & $\begin{array}{c}0.02 \\
(0.49)\end{array}$ \\
\hline $\begin{array}{l}\text { Maj * Auto * } \\
\text { Too much }\end{array}$ & $\begin{array}{l}-2.25 \\
(1.21)\end{array}$ & $\begin{array}{l}-1.07 \\
(1.34)\end{array}$ & $\begin{array}{l}-2.33 \\
(1.24)\end{array}$ & $\begin{array}{l}-1.68 \\
(1.41)\end{array}$ & $\begin{array}{l}-1.00 \\
(0.56)\end{array}$ & $\begin{array}{l}-0.75 \\
(0.62\end{array}$ \\
\hline $\begin{array}{l}\text { Auto*Too little * } \\
\text { USA }\end{array}$ & $\begin{array}{c}0.52 \\
(0.87)\end{array}$ & $\begin{array}{c}0.19 \\
(0.97)\end{array}$ & $\begin{array}{l}-0.43 \\
(0.89\end{array}$ & $\begin{array}{l}-1.06 \\
(0.99\end{array}$ & $\begin{array}{l}-0.19 \\
(0.41)\end{array}$ & $\begin{array}{l}-0.40 \\
(0.44)\end{array}$ \\
\hline $\begin{array}{l}\text { Auto*Sufficient* } \\
\text { USA }\end{array}$ & $\begin{array}{c}0.47 \\
(0.84)\end{array}$ & $\begin{array}{c}0.43 \\
(0.93)\end{array}$ & $\begin{array}{l}-0.17 \\
(0.86)\end{array}$ & $\begin{array}{l}-0.77 \\
(0.95)\end{array}$ & $\begin{array}{l}-0.04 \\
(0.39)\end{array}$ & $\begin{array}{l}-0.18 \\
(0.43)\end{array}$ \\
\hline $\begin{array}{l}\text { Auto*Too much } \\
* \text { USA }\end{array}$ & $\begin{array}{c}0.45 \\
(0.98)\end{array}$ & $\begin{array}{c}0.45 \\
(1.09)\end{array}$ & $\begin{array}{r}0.59 \\
(1.02\end{array}$ & $\begin{array}{c}0.27 \\
(1.13\end{array}$ & $\begin{array}{c}0.24 \\
(0.46)\end{array}$ & $\begin{array}{c}0.11 \\
(0.50)\end{array}$ \\
\hline $\begin{array}{l}\text { Maj*Too little * } \\
\text { USA }\end{array}$ & $\begin{array}{l}-1.03 \\
(0.97)\end{array}$ & $\begin{array}{l}-0.69 \\
(1.08)\end{array}$ & $\begin{array}{l}-1.89 * \\
(0.96)\end{array}$ & $\begin{array}{l}-1.80 \\
(1.08)\end{array}$ & $\begin{array}{l}-0.80 \\
(0.45)\end{array}$ & $\begin{array}{l}-0.68 \\
(0.49)\end{array}$ \\
\hline $\begin{array}{l}\text { Maj*Sufficient* } \\
\text { USA }\end{array}$ & $\begin{array}{l}-0.15 \\
(0.94)\end{array}$ & $\begin{array}{c}0.18 \\
(1.04)\end{array}$ & $\begin{array}{l}-0.96 \\
(0.93)\end{array}$ & $\begin{array}{l}-1.06 \\
(1.04)\end{array}$ & $\begin{array}{l}-0.28 \\
(0.43)\end{array}$ & $\begin{array}{l}-0.27 \\
(0.47)\end{array}$ \\
\hline $\begin{array}{l}\text { Maj*Too much * } \\
\text { USA }\end{array}$ & $\begin{array}{l}-1.35 \\
(1.00)\end{array}$ & $\begin{array}{l}-0.95 \\
(1.11)\end{array}$ & $\begin{array}{l}-1.92 \\
(1.02)\end{array}$ & $\begin{array}{l}-1.82 \\
(1.12)\end{array}$ & $\begin{array}{l}-0.65 \\
(0.46)\end{array}$ & $\begin{array}{l}-0.55 \\
(0.50)\end{array}$ \\
\hline $\begin{array}{l}\text { Maj*Auto*USA* } \\
\text { Too little }\end{array}$ & $\begin{array}{l}1.13 \\
(1.25)\end{array}$ & $\begin{array}{c}0.62 \\
(1.39)\end{array}$ & $\begin{array}{l}2.08 \\
(1.25)\end{array}$ & $\begin{array}{c}2.51 \\
(1.40)\end{array}$ & $\begin{array}{c}0.87 \\
(0.57)\end{array}$ & $\begin{array}{c}0.90 \\
(0.63)\end{array}$ \\
\hline $\begin{array}{l}\text { Maj*Auto*USA* } \\
\text { Sufficient }\end{array}$ & $\begin{array}{c}0.69 \\
(1.21)\end{array}$ & $\begin{array}{c}0.37 \\
(1.34)\end{array}$ & $\begin{array}{c}1.19 \\
(1.21)\end{array}$ & $\begin{array}{c}2.04 \\
(1.35)\end{array}$ & $\begin{array}{c}0.46 \\
(0.55)\end{array}$ & $\begin{array}{c}0.65 \\
(0.60)\end{array}$ \\
\hline $\begin{array}{l}\text { Maj*Auto*USA* } \\
\text { Too much }\end{array}$ & $\begin{array}{c}2.18 \\
(1.47)\end{array}$ & $\begin{array}{c}0.59 \\
(1.68)\end{array}$ & $\begin{array}{c}2.02 \\
(1.49)\end{array}$ & $\begin{array}{c}1.35 \\
(1.73)\end{array}$ & $\begin{array}{c}0.96 \\
(0.67)\end{array}$ & $\begin{array}{c}0.56 \\
(0.75)\end{array}$ \\
\hline $\begin{array}{c}\mathbf{N} \\
\text { Link } \\
\text { AIC }\end{array}$ & $\begin{array}{c}3196 \\
\text { Logit } \\
7283.77\end{array}$ & $\begin{array}{c}2622 \\
\text { Logit } \\
5954.92\end{array}$ & $\begin{array}{c}3196 \\
\text { Logit } \\
6893.77\end{array}$ & $\begin{array}{c}2622 \\
\text { Logit } \\
5551.18\end{array}$ & $\begin{array}{c}3196 \\
8175.985\end{array}$ & $\begin{array}{c}2622 \\
6686.323\end{array}$ \\
\hline
\end{tabular}

Table SI-5.1: ${ }^{* * *} \mathrm{p}<0.001,{ }^{* *} \mathrm{p}<0.01,{ }^{*} \mathrm{p}<0.05$. We use an ordinal logistic regression to calculate the results for APPROPRIATENESS and DEFERENCE. We use an OLS to calculate results for 5-ITEM. Reduced samples are the participants who answered all three comprehension questions correctly by their second attempt. 
SI-5 (b) Interaction between Authority and Political Ideology

We interacted political ideology with the treatments. YouGov uses different questions for political ideology in Germany and the US. Therefore, we ran the analyses separately. Table SI-5.2 lists results for Germany and Table SI-5.3 for the US.

Germany: In political matters, people talk of " left" and "right". How would you place your views on this scale? (1-Left to 10-Right)

United States: In general, how would you describe your own political viewpoint? (Very liberal, Liberal, Moderate, Conservative, Very conservative, Not sure)

\begin{tabular}{|l|c|c|c|c|c|c|}
\hline & \multicolumn{2}{|c|}{ Appropriateness } & \multicolumn{2}{c|}{ Deference } & \multicolumn{2}{c|}{ 5-ITEM } \\
\hline & Full & Reduced & Full & Reduced & Full & Reduced \\
\hline Majority & 0.08 & 0.05 & -0.07 & -0.12 & -0.07 & -0.16 \\
& $(0.44)$ & $(0.48)$ & $(0.46)$ & $(0.51)$ & $(0.13)$ & $(0.13)$ \\
Auto & 0.41 & 0.32 & 0.52 & 0.47 & 0.08 & 0.06 \\
Left_Right & $(0.44)$ & $(0.47)$ & $(0.47)$ & $(0.51)$ & $(0.18)$ & $(0.19)$ \\
& -0.03 & -0.06 & -0.12 & -0.13 & $-0.06 *$ & $-0.07 *$ \\
Maj*Auto & $(0.06)$ & $(0.06)$ & $(0.06)$ & $(0.07)$ & $(0.17)$ & $(0.18)$ \\
Auto*Left_Right & 0.45 & 0.11 & -0.24 & -0.47 & 0.11 & 0.10 \\
& $(0.63)$ & $(0.69)$ & $(0.66)$ & $(0.73)$ & $(0.02)$ & $(0.03)$ \\
Maj*Left_Right & -0.02 & -0.01 & -0.08 & -0.09 & -0.01 & -0.01 \\
& $(0.08)$ & $(0.09)$ & $(0.09)$ & $(0.10)$ & $(0.25)$ & $(0.27)$ \\
Maj*Auto*Left_Right & 0.00 & -0.01 & -0.01 & -0.01 & 0.01 & 0.03 \\
& $(0.09)$ & $(0.09)$ & $(0.09)$ & $(0.10)$ & $(0.03)$ & $(0.04)$ \\
& -0.14 & -0.05 & 0.02 & 0.10 & -0.03 & -0.02 \\
N & $(0.12)$ & $(0.13)$ & $(0.13)$ & $(0.14)$ & $(0.05)$ & $(0.05)$ \\
\hline Link & 1600 & 1354 & 1600 & 1354 & 1600 & 1354 \\
AIC & Logit & Logit & Logit & Logit & & \\
& 3481.08 & 2981.65 & 3040.91 & 2553.84 & 3607.593 & 3044.65 \\
\hline
\end{tabular}

Table SI-5.2: ${ }^{* * *} \mathrm{p}<0.001,{ }^{* *} \mathrm{p}<0.01,{ }^{*} \mathrm{p}<0.05$. Results for Germany: We use an ordinal logistic regression to calculate the results for APPROPRIATENESS and DEFERENCE. We use an OLS to calculate results for 5-ITEM.

Reduced samples are the participants who answered all three comprehension questions correctly by their second attempt. 


\begin{tabular}{|l|c|c|c|c|c|c|}
\hline & \multicolumn{2}{|c|}{ Appropriateness } & \multicolumn{2}{c|}{ Deference } & \multicolumn{2}{c|}{ 5-ITEM } \\
\hline & Full & Reduced & Full & Reduced & Full & Reduced \\
\hline Majority & 0.21 & 0.31 & 0.26 & 0.38 & 0.10 & 0.20 \\
\multirow{5}{*}{ Auto } & $(0.47)$ & $(0.41)$ & $(0.45)$ & $(0.40)$ & $(0.20)$ & $(0.15)$ \\
& -0.09 & -0.13 & 0.33 & 0.26 & 0.17 & 0.17 \\
Left_Right & $(0.48)$ & $(0.42)$ & $(0.47)$ & $(0.41)$ & $(0.21)$ & $(0.21)$ \\
& $-0.86 * * *$ & $-0.52 * * *$ & $-0.77 * * *$ & $-0.45 * * *$ & $-0.44 * * *$ & $-0.29 * * *$ \\
Maj*Auto & $(0.10)$ & $(0.08)$ & $(0.10)$ & $(0.08)$ & $(0.05)$ & $(0.04)$ \\
& -0.07 & 0.03 & -0.22 & -0.06 & -0.14 & -0.13 \\
Auto*Left_Right & $(0.66)$ & $(0.59)$ & $(0.64)$ & $(0.58)$ & $(0.28)$ & $(0.29)$ \\
Maj*Left_Right & -0.06 & 0.03 & -0.14 & -0.07 & -0.09 & -0.06 \\
& $(0.15)$ & $(0.12)$ & $(0.14)$ & $(0.12)$ & $(0.07)$ & $(0.06)$ \\
Maj*Auto*Left_Right & -0.09 & -0.09 & -0.08 & -0.10 & -0.03 & -0.05 \\
& $(0.14)$ & $(0.12)$ & $(0.14)$ & $(0.12)$ & $(0.06)$ & $(0.06)$ \\
N & 0.14 & 0.06 & 0.12 & 0.05 & 0.08 & 0.07 \\
Link & $(0.20)$ & $(0.17)$ & $(0.20)$ & $(0.17)$ & $(0.09)$ & $(0.08)$ \\
\hline AIC & 1461 & 1270 & 1461 & 1270 & 1461 & 1270 \\
& Logit & Logit & Logit & Logit & & \\
& 3263.37 & 2933.29 & 3362.18 & 3010.13 & 3979.95 & 3585.55 \\
\hline
\end{tabular}

Table SI-5.3: ${ }^{* * *} \mathrm{p}<0.001,{ }^{* *} \mathrm{p}<0.01,{ }^{*} \mathrm{p}<0.05$. Results for US: We use an ordinal logistic regression to calculate the results for APPROPRIATENESS and DEFERENCE. We use an OLS to calculate results for 5-ITEM. Reduced samples are the participants who answered all three comprehension questions correctly by their second attempt. 
SI-6 Other factors influencing legitimacy perceptions

\begin{tabular}{|c|c|c|c|c|c|c|}
\hline & $\begin{array}{c}\text { Undemocratic } \\
\text { (Full) }\end{array}$ & $\begin{array}{c}\text { Undemocratic } \\
\text { (Reduced) }\end{array}$ & $\begin{array}{c}\text { Pressure } \\
\text { (Full) }\end{array}$ & $\begin{array}{c}\text { Pressure } \\
\text { (Reduced) }\end{array}$ & $\begin{array}{c}\text { Ineffective } \\
\text { (Full) }\end{array}$ & $\begin{array}{c}\text { Ineffective } \\
\text { (Reduced) }\end{array}$ \\
\hline Majority & -0.08 & -0.07 & -0.06 & -0.03 & -0.01 & 0.02 \\
& $(0.14)$ & $(0.14)$ & $(0.13)$ & $(0.14)$ & $(0.13)$ & $(0.14)$ \\
Automatic & 0.14 & 0.13 & -0.04 & -0.06 & -0.14 & -0.15 \\
& $(0.14)$ & $(0.15)$ & $(0.13)$ & $(0.14)$ & $(0.14)$ & $(0.14)$ \\
USA & 0.26 & 0.09 & $0.80 * * *$ & $0.73 * * *$ & -0.13 & -0.24 \\
& $(0.15)$ & $(0.15)$ & $(0.14)$ & $(0.14)$ & $(0.14)$ & $(0.15)$ \\
Majority*Automatic & -0.07 & -0.05 & 0.11 & 0.10 & 0.003 & 0.03 \\
& $(0.20)$ & $(0.21)$ & $(0.19)$ & $(0.20)$ & $(0.19)$ & $(0.20)$ \\
Majority*USA & -0.09 & 0.05 & -0.16 & -0.10 & 0.16 & 0.18 \\
& $(0.21)$ & $(0.22)$ & $(0.20)$ & $(0.20)$ & $(0.20)$ & $(0.21)$ \\
Automatic*USA & -0.15 & -0.02 & 0.09 & 0.14 & 0.02 & 0.18 \\
& $(0.21)$ & $(0.22)$ & $(0.20)$ & $(0.21)$ & $(0.20)$ & $(0.22)$ \\
Majority*Automatic & -0.16 & -0.36 & -0.47 & -0.46 & -0.32 & -0.40 \\
*USA & $(0.29)$ & $(0.32)$ & $(0.28)$ & $(0.30)$ & $(0.28)$ & $(0.30)$ \\
& & & & & & \\
\hline N & 2463 & 2189 & 2765 & 2446 & 2693 & 2383 \\
Link & logit & logit & logit & logit & logit & logit \\
AIC & 6565.49 & 5729.68 & 7460.60 & 6565.53 & 6889.42 & 6033.41 \\
\hline
\end{tabular}

Table SI-6.1: ${ }^{* * *} \mathrm{p}<0.001,{ }^{* *} \mathrm{p}<0.01,{ }^{*} \mathrm{p}<0.05$. We use an ordinal logistic regression to calculate the results. Undemocratic, Pressure, and Ineffective are ordinal variables with response categories: agree, somewhat agree, somewhat disagree, and disagree. 


\begin{tabular}{|c|c|}
\hline United States & Germany \\
\hline $\begin{array}{l}\text { Please read the following statement carefully. If you choose to participate in } \\
\text { this survey, please click on the button next to "I have read and understood } \\
\text { the consent form and agree to participate in this survey." If you choose not to } \\
\text { participate, please click on the "Cancel" button at the bottom of this page. }\end{array}$ & $\begin{array}{l}\text { Bitte lesen Sie die folgende Erklärung sorgfältig durch.Wenn Sie an dieser } \\
\text { Umfrage teilnehmen möchten, wählen Sie bitte die Option „Ich habe die } \\
\text { Erklärung gelesen und verstanden und willige ein, an der Umfrage } \\
\text { teilzunehmen.“ Wenn Sie nicht an dieser Umfrage teilnehmen möchten, } \\
\text { wählen Sie bitte die Option „Abbrechen“. }\end{array}$ \\
\hline $\begin{array}{l}\text { This survey is carried out for a research project led by Professor Thomas } \\
\text { Bernauer from ETH Zürich. Its objective is to better understand personal } \\
\text { opinions concerning international politics. This survey is for scientific } \\
\text { purposes only. It has no commercial or government-related purpose. There } \\
\text { are no known risks or costs when participating in the survey. The } \\
\text { information you provide will help us understand opinions concerning } \\
\text { international politics. This survey is anonymous. The information you } \\
\text { provide in this survey will not be stored or used in any way that could } \\
\text { reveal your personal identity. }\end{array}$ & $\begin{array}{l}\text { Diese Umfrage ist Teil eines Forschungsprojekts der ETH Zürich, das von } \\
\text { Professor Thomas Bernauer geleitet wird. Ziel der Umfrage ist ein besseres } \\
\text { Verständnis über persönliche Meinungen zur internationalen Politik. Ihre } \\
\text { Angaben werden ausschließlich für wissenschaftliche Zwecke ausgewertet. } \\
\text { Die Teilnahme an der Umfrage ist freiwillig und birgt keine bekannten } \\
\text { Risiken oder Kosten. Die von Ihnen zur Verfügung gestellten Informationen } \\
\text { werden anonymisiert ausgewertet und gespeichert, sodass keine } \\
\text { Rückschlüsse auf Ihre Person möglich sind. }\end{array}$ \\
\hline $\begin{array}{l}\text { If you have any questions or concerns about completing the questionnaire or } \\
\text { about participating in this survey, you may contact us at } \\
\text { thbesurveyone@gess.ethz.ch or write to Thomas Bernauer, ETH Zürich, } \\
\text { Haldeneggsteig 4, } 8092 \text { Zürich, Switzerland. The ETH Zürich Ethics Review } \\
\text { Commission has reviewed and approved this project. If you have any } \\
\text { concerns about your rights in this survey, please contact us at } \\
\text { thbesurveyone@gess.ethz.ch or Raffael Iturrizaga from the ETH Zürich } \\
\text { Ethics Review Commission at raffael.iturrizaga@sl.ethz.ch or +41 } 44632 \\
2354 \text { with reference to its decision EK 2012-N-41. } \\
\text { (1) I have read and understood the consent form and agree to participate in } \\
\text { the survey } \\
\text { (2) Cancel }\end{array}$ & $\begin{array}{l}\text { Wenn Sie Fragen oder Anliegen zum Fragebogen oder zur Teilnahme an } \\
\text { dieser Umfrage haben, können Sie den Projektleiter per E-Mail } \\
\text { (thbesurveyone@gess.ethz.ch) oder auf dem Postweg (Thomas Bernauer, } \\
\text { ETH Zürich, Haldeneggsteig 4, 8092 Zürich, Schweiz) kontaktieren. Die } \\
\text { Ethikkommission der ETH Zürich hat dieses Forschungsprojekt überprüft } \\
\text { und genehmigt. Bei Fragen zu diesem Punkt können Sie sich an Raffael } \\
\text { Iturrizaga von der Ethikkommission der ETH Zürich unter } \\
\text { raffael.iturrizaga@ethz.ch oder unter +41 } 446322354 \text { mit Verweis auf den } \\
\text { Beschluss EK 2012-N-41 wenden. } \\
\text { (1) Ich habe die Erklärung gelesen und verstanden und willige ein, an der } \\
\text { Umfrage teilzunehmen } \\
\text { (2) Abbrechen }\end{array}$ \\
\hline
\end{tabular}


Welcome to the survey. Our research will only produce meaningful results if you read and think about each question carefully and express your true opinion. Thank you for keeping this in mind! We anticipate that the survey will take you no longer than 15 minutes to complete. Please take your time. We greatly appreciate your contribution. Lastly, please avoid using the 'Back' button of your browser during the Survey.
Willkommen zu dieser Umfrage. Unsere Studie kann nur dann

aussagekräftige Ergebnisse hervorbringen, wenn Sie jede Frage aufmerksam lesen, darüber nachdenken und Ihre tatsächliche Meinung wiedergeben.

Vielen Dank, dass Sie dies berücksichtigen! Wir gehen davon aus, dass die Umfrage Sie nicht länger als 15 Minuten in Anspruch nehmen wird. Bitte lassen Sie sich Zeit. Wir schätzen Ihre Mitwirkung sehr. Bitte verwenden Sie während der Umfrage nicht die 'Zurück'-Taste Ihres Internetbrowsers.

\section{Explanation of Climate Change}

We burn large amounts of coal, oil and gas when producing energy and in transportation. When we burn these fossil fuels, we emit carbon dioxide $\left(\mathrm{CO}_{2}\right)$ into the atmosphere. Growing amounts of carbon dioxide $\left(\mathrm{CO}_{2}\right)$ in the atmosphere cause the global temperature to rise. This is commonly referred to as climate change or global warming. To prevent further temperature increases, governments from around the world are meeting to design a worldwide strategy.

\section{Description of Global Climate Conference}

Specifically, governments meet annually at the Global Climate Conference, which includes 190 countries along with the United States. Their aim is to negotiate an international agreement to reduce carbon dioxide $\left(\mathrm{CO}_{2}\right)$ emissions worldwide. This meeting is also known as the Conference of the Parties to the Framework Convention on Climate Change.

Negotiations at the Global Climate Conference focus on two issues:

- How much should worldwide carbon dioxide $\left(\mathrm{CO}_{2}\right)$ emissions be reduced?

- How much should each country reduce its carbon dioxide $\left(\mathrm{CO}_{2}\right)$ emissions

to achieve the worldwide goal?

Wir verbrennen große Mengen an Kohle, Öl und Gas bei der Energieproduktion und im Transportwesen. Bei der Verbrennung dieser fossilen Energieträger stoßen wir Kohlendioxid $\left(\mathrm{CO}_{2}\right)$ in die Erdatmosphäre aus. Zunehmende Mengen an $\mathrm{CO}_{2}$ in der Erdatmosphäre verursachen steigende Temperaturen weltweit. Dies wird gemeinhin als Klimawandel oder globale Erderwärmung bezeichnet. Um weitere Temperaturanstiege zu verhindern, treffen sich Regierungen aus aller Welt um globale Maßnahmen auszuarbeiten.

Konkret treffen sich die Regierungen jährlich zur Weltklimakonferenz, an der insgesamt 190 Staaten teilnehmen, inklusive Deutschland. Ihr Ziel ist es, ein internationales Ankommen zur weltweiten Reduktion der Emissionen von Kohlendioxid $\left(\mathrm{CO}_{2}\right)$ auszuhandeln. Dieses Treffen ist auch bekannt als Konferenz der Vertragsparteien des Rahmenabkommens über Klimaveränderungen.

Verhandlungen an der Weltklimakonferenz konzentrieren sich auf zwei Fragestellungen:

- Um wie viel soll der weltweite Kohlendioxidausstoß $\left(\mathrm{CO}_{2}\right)$ insgesamt reduziert werden?

- Um wie viel soll jedes einzelne Land seinen Kohlendioxidausstoß $\left(\mathrm{CO}_{2}\right)$ reduzieren, um das weltweite Gesamtziel zu erreichen? 


\section{Comprehension Check}

If question below answered incorrectly, redirect to previous page. After which, participants continue regardless.

According to what you read on the previous page, the Global Climate Conference's purpose is to:

- Reduce carbon dioxide $\left(\mathrm{CO}_{2}\right)$ emissions

- Prevent melting of the ice in the Arctic

- Prevent the extinction of endangered species

- Don't know
Gemäß den Informationen, die Sie auf der vorherigen Seite gelesen haben, ist das Ziel der Weltklimakonferenz:

- Den Ausstoß von Kohlendioxid $\left(\mathrm{CO}_{2}\right)$ zu verringern

- Das Schmelzen des Arktischen Eises zu verhindern

- Das Aussterben von bedrohten Arten zu verhindern

- Ich weiß nicht

\section{International Voting Treatment}

Randomly assign participants to either majority or consensus voting

\section{Majority}

At the meeting, countries negotiate their positions and draft a proposed agreement. Once countries complete these negotiations, they will vote for or against a proposed agreement. As mentioned before, the proposed agreement focuses on two issues:

- How much should worldwide carbon dioxide $\left(\mathrm{CO}_{2}\right)$ emissions be reduced? - How much should each country reduce its carbon dioxide $\left(\mathrm{CO}_{2}\right)$ emissions to achieve the worldwide goal?

The voting rule is as follows:

- If more than half of the participating countries (the majority) vote in favor of the proposed agreement, then the proposed agreement will pass and negotiations will end even if the United States voted against.

- If more than half of the participating countries vote against the proposed agreement, then the proposed agreement will not pass even if the United States voted in favor. In that case, there is no agreement and countries
Auf der Weltklimakonferenz verhandeln die Staaten ihre Positionen und formulieren einen Entwurf für ein internationales Abkommen zur Reduktion der weltweiten Emissionen von Kohlendioxid. Sobald die Staaten ihre Verhandlungen über ein solches Abkommen abgeschlossen haben, findet eine Abstimmung über den ausgehandelten Entwurf statt. Jeder Staat kann dann für oder gegen den Entwurf des Abkommens stimmen. Wie bereits erwähnt, konzentriert sich das vorgesehene Abkommen auf zwei Punkte: - Um wie viel soll der weltweite Kohlendioxidausstoß $\left(\mathrm{CO}_{2}\right)$ insgesamt reduziert werden?

- Um wie viel soll jedes einzelne Land seine Emissionen von Kohlendioxid $\left(\mathrm{CO}_{2}\right)$ reduzieren, um das weltweite Gesamtziel zu erreichen?

Die Abstimmungsregel lautet wie folgt:

- Wenn mehr als die Hälfte der teilnehmenden Staaten (die Mehrheit) für den Entwurf des Abkommens stimmt, dann gilt der Entwurf als 


\begin{tabular}{|c|c|}
\hline will resume negotiations next year. & $\begin{array}{l}\text { beschlossen und die Verhandlungen sind beendet. Das Abkommen kann also } \\
\text { auch dann zustande kommen, wenn Deutschland dagegen stimmt. } \\
\text { • Wenn mehr als die Hälfte der teilnehmenden Länder gegen den } \\
\text { Entwurf des Abkommens stimmt, dann gilt der Entwurf als abgelehnt. In } \\
\text { diesem Fall kommt kein Abkommen zustande und die Staaten werden ihre } \\
\text { Verhandlungen im nächsten Jahr wiederaufnehmen. Das Abkommen kann } \\
\text { also auch dann abgelehnt werden und nicht zustande kommen, wenn } \\
\text { Deutschland dafür stimmt. }\end{array}$ \\
\hline \multicolumn{2}{|l|}{ Consensus } \\
\hline $\begin{array}{l}\text { At the meeting, countries negotiate their positions and draft a proposed } \\
\text { agreement. Once countries complete these negotiations, they will vote for or } \\
\text { against a proposed agreement. As mentioned before, the proposed agreement } \\
\text { focuses on two issues: } \\
\text { - How much should worldwide carbon dioxide }\left(\mathrm{CO}_{2}\right) \text { emissions be reduced? } \\
\text { - How much should each country reduce its carbon dioxide }\left(\mathrm{CO}_{2}\right) \text { emissions } \\
\text { to achieve the worldwide goal? } \\
\text { - } \\
\text { The voting rule is the following: } \\
\text { - If all participating countries (unanimity) vote in favor of the proposed } \\
\text { agreement, then the proposed agreement will pass and negotiations will end } \\
\text { as long as the United States also votes in favor. } \\
\text { - If any participating country votes against the proposed agreement, then } \\
\text { the proposed agreement will not pass even ifthe United States voted in favor. } \\
\text { In that case, there is no agreement and countries will resume negotiations } \\
\text { next year. }\end{array}$ & $\begin{array}{l}\text { Auf der Weltklimakonferenz verhandeln die Staaten ihre Positionen und } \\
\text { formulieren einen Entwurf für ein internationales Abkommen zur Reduktion } \\
\text { der weltweiten Emissionen von Kohlendioxid. Sobald die Staaten ihre } \\
\text { Verhandlungen über ein solches Abkommen abgeschlossen haben, findet } \\
\text { eine Abstimmung über den ausgehandelten Entwurf statt. Jeder Staat kann } \\
\text { dann für oder gegen den Entwurf des Abkommens stimmen. Wie bereits } \\
\text { erwähnt, konzentriert sich das vorgesehene Abkommen auf zwei Punkte: } \\
\text { • Um wie viel soll der weltweite Kohlendioxidausstoß (CO } 2) \text { insgesamt } \\
\text { reduziert werden? } \\
\text { • Um wie viel soll jedes einzelne Land seine Emissionen von Kohlendioxid } \\
\left.\text { (CO }{ }_{2}\right) \text { reduzieren, um das weltweite Gesamtziel zu erreichen? } \\
\text { Die Abstimmungsregel lautet wie folgt: } \\
\text { • Wenn alle teilnehmenden Staaten einstimmig für den Entwurf des } \\
\text { Abkommen stimmen, dann gilt der Entwurf als beschlossen und die } \\
\text { Verhandlungen sind beendet. Das Abkommen kann also nur dann zustande } \\
\text { kommen, wenn auch Deutschland dafür stimmt. } \\
\text { • Wenn irgendeiner der teilnehmenden Staaten gegen den Entwurf des } \\
\text { Abkommen stimmt, dann gilt der Entwurf als abgelehnt. In diesem Fall } \\
\text { kommt kein Abkommen zustande und die Staaten werden ihre } \\
\text { Verhandlungen im nächsten Jahr wiederaufnehmen. Das Abkommen kann } \\
\text { also auch dann abgelehnt werden und nicht zustande kommen, wenn } \\
\text { Deutschland dafür stimmt. }\end{array}$ \\
\hline
\end{tabular}




\section{Comprehension Check: International Voting \\ If question below answered incorrectly, redirect to previous page. After which, participants continue regardless.}

According to what you just read on the previous page, a proposed agreement will pass:

- If the majority of countries votes in favor even if the United States votes against

- Only if all countries, including the United States, vote in favor

- Don't know
Gemäß den Informationen, welche Sie auf der vorherigen Seite gelesen haben, gilt der Entwurf für ein Abkommen als beschlossen:

- Sobald die Mehrheit der Staaten zustimmt, selbst wenn Deutschland dagegen stimmt

- Sobald alle Staaten, einschließlich Deutschland, dafür stimmen

- Ich weiß nicht

\section{Domestic Ratification Treatment}

\section{Randomly assign participants to either automatic implementation or approval by legislature}

\section{Automatic Implementation}

Once international negotiations end and if an agreement passes, the agreement needs to be implemented within participating countries (at the domestic level). Imagine that all countries participating in the Global Climate Conference, including the United States, decided before the negotiations to automatically implement an agreement if one is passed. This means that if the Conference passes an agreement, the United States must reduce its carbon dioxide $\left(\mathrm{CO}_{2}\right)$ emissions by the amount specified in that agreement. However, if the Conference does not pass an agreement, the United States has no obligation to reduce its carbon dioxide $\left(\mathrm{CO}_{2}\right)$ emissions.
Sobald die internationalen Verhandlungen beendet sind und ein Vertragsentwurf nach der gültigen Abstimmungsregel angenommen worden ist, muss dieses Abkommen im nächsten Schritt von den einzelnen Staaten auf der nationalen Ebene umgesetzt werden. Stellen Sie sich vor, dass vor den internationalen Verhandlungen alle Staaten, die an der Weltklimakonferenz teilnehmen - einschließlich Deutschland - Folgendes beschlossen haben: Alle teilnehmenden Staaten der Weltklimakonferenz müssenautomatisch einen im Rahmen der Verhandlungen angenommenen Vertragsentwurf umsetzen. Das bedeutet, dass Deutschland den eigenen Ausstoß von Kohledioxid $\left(\mathrm{CO}_{2}\right)$ um die im Abkommen festgelegte Menge verringern muss. Sollte an der Weltklimakonferenz jedoch kein Abkommen zustande kommen, so hat Deutschland keine Verpflichtung, den eigenen Ausstoß von Kohlendioxid $\left(\mathrm{CO}_{2}\right)$ zu verringern.

\section{Legislature}


Once international negotiations end and if an agreement passes, the agreement needs to be implemented within participating countries (at the domestic level). Imagine that all countries participating in the Global Climate Conference, including the United States, decided before the negotiations to implement an agreement reached by the Conference only after their respective parliament/legislature back home has approved the agreement as well. This means that if Congress approves the agreement, the United States must reduce its carbon dioxide $\left(\mathrm{CO}_{2}\right)$ emissions by the amount specified in that agreement. However, if Congress does not approve the agreement, the United States has no obligation to reduce its carbon $\left(\mathrm{CO}_{2}\right)$ emissions.

Comprehension Check: Domestic Ratification

If question below answered incorrectly, redirect to previous page. After which, participants continue regardless.

According to what you read on the previous page, once the Climate

Conference reaches an agreement, the United States:

- Must implement the agreement only if the Environmental Protection

Agency approves the agreement

- Must implement the agreement only if Congress approves the agreement

- Must automatically implement the agreement

- Don't know
Sobald die internationalen Verhandlungen beendet sind und ein Entwurf für ein Abkommen nach der gültigen Abstimmungsregel angenommen worden ist, muss dieses Abkommen im nächsten Schritt von den einzelnen Staaten auf der nationalen Ebene umgesetzt werden. Stellen Sie sich vor, dass alle an der Weltklimakonferenz teilnehmenden Staaten, einschließlich Deutschland, vor den Verhandlungen vereinbart haben, dass ein im Rahmen der

\section{Verhandlungen angenommener Entwurf für das Abkommen nur dann} innerhalb der teilnehmenden Staaten umgesetzt werden muss, wenn die jeweiligen nationalen Parlamente das Abkommen genehmigen. Das bedeutet, dass Deutschland den eigenen Ausstoß von Kohledioxid $\left(\mathrm{CO}_{2}\right)$ um die im Abkommen festgelegte Menge nur dann verringern muss, wenn der Bundestag und Bundesrat dem Abkommen zustimmt. Sollte der Bundestag und Bundesrat dem Abkommen jedoch nicht zustimmen, so hat Deutschland keine Verpflichtung, den eigenen Ausstoß von Kohlendioxid $\left(\mathrm{CO}_{2}\right) \mathrm{zu}$ verringern.

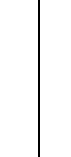

\section{Show Corresponding Flow Chart of Global Climate Conference Procedure}

We would like to know your opinion about the Global Climate Conference

Wir interessieren uns für Ihre Meinung zur Weltklimakonferenz, wie sie auf as it was described a moment ago.

Gemäß der Informationen, die Sie auf der vorherigen Seite gelesen haben. Sobald bei der Weltklimakonferenz ein Entwurf für ein Abkommen zustande gekommen ist, muss Deutschland:

- Das Abkommen nur dann umsetzen, wenn das Bundesumweltministerium das Abkommen genehmigt

- Das Abkommen nur dann umsetzen, wenn der Bundestag und der Bundesrat dem Abkommen zustimmen

- Das Abkommen automatisch umsetzen

- Ich weiß nicht 


\begin{tabular}{|c|c|}
\hline & Fragen stellen. \\
\hline \multicolumn{2}{|l|}{$\begin{array}{l}\text { 5-ITEM Legitimacy Measure } \\
\text { Randomize the order of the items and the direction of the scale between participants }\end{array}$} \\
\hline $\begin{array}{l}\text { Please state the extent to which you agree, somewhat agree, somewhat } \\
\text { disagree or disagree with the following statements: } \\
\text { - I believe the Global Climate Conference is necessary. } \\
\text { - The principles of the Global Climate Conference match my own. } \\
\text { - I sympathize with the goals of the Global Climate Conference. } \\
\text { - I think the Global Climate Conference serves an important role in society. } \\
\text { - The Global Climate Conference should continue to make decisions in the } \\
\text { future. }\end{array}$ & $\begin{array}{l}\text { Bitte geben Sie an, ob Sie den folgenden Aussagen zustimmen, eher } \\
\text { zustimmen, sie eher ablehnen oder ablehnen: } \\
\text { • Ich glaube, dass die Weltklimakonferenz notwendig ist. } \\
\text { • Die Werte der Weltklimakonferenz stimmen mit meinen eigenen Werten } \\
\text { überein. } \\
\text { - Ich teile die Ziele der Weltklimakonferenz. } \\
\text { - Ich denke, dass die Weltklimakonferenz eine wichtige Rolle in der } \\
\text { Gesellschaft spielt. } \\
\text { • Die Weltklimakonferenz sollte auch in der Zukunft Entscheidungen treffen. }\end{array}$ \\
\hline \multicolumn{2}{|l|}{ Fairness Measure } \\
\hline $\begin{array}{l}\text { I believe that this way of deciding how much countries, including the United } \\
\text { States, must reduce carbon dioxide }\left(\mathrm{CO}_{2}\right) \text { emissions is the right way to find a } \\
\text { solution to the climate change problem. } \\
\text { - Disagree } \\
\text { - Somewhat disagree } \\
\text { - Somewhat agree } \\
\text { - Agree }\end{array}$ & $\begin{array}{l}\text { Bitte sagen Sie uns ob Sie der folgenden Aussage zustimmen oder diese } \\
\text { ablehnen: Der beschriebene Prozess legt fest, um wie viel die beteiligten } \\
\text { Staaten, darunter auch Deutschland, ihren Ausstoß von Kohlendioxid } \\
\text { reduzieren müssen }\left(\mathrm{CO}_{2}\right) \text {. Dies ist der richtige Weg zur Lösung des } \\
\text { Klimawandelproblems. } \\
\text { - Lehne ab } \\
\text { - Lehne eher ab } \\
\text { - Stimme eher zu } \\
\text { - Stimme zu }\end{array}$ \\
\hline \multicolumn{2}{|l|}{$\begin{array}{l}\text { Manipulation Check } \\
\text { Did participants perceive the varying levels of authority? }\end{array}$} \\
\hline $\begin{array}{l}\text { Do you think this process from the previous pages describing whether and } \\
\text { how much the United States must reduce its carbon dioxide emissions gives } \\
\text { the United States too little or too much control over this policy? }\end{array}$ & $\begin{array}{l}\text { Denken Sie nochmals an den Abstimmungs- und Umsetzungsprozess bei der } \\
\text { Weltklimakonferenz und auf der nationalen Ebene, so wie dieser auf den } \\
\text { vorherigen Seiten beschrieben wurde. Finden Sie, dass dieser Prozess }\end{array}$ \\
\hline
\end{tabular}




\section{- No control \\ - Too little control \\ - Sufficient control \\ - Too much control}

\section{Climate Change Concern}

Randomize the order of questions and the direction of response categories between participants

When do you think global climate change will harm people?

- It will never harm people

- It will not harm people for many years

- It will harm people in the next few years

- It is harming people around the world now

In your view, how serious of a problem is global climate change?

- Not a problem

- Not too serious

- Somewhat serious

- Very serious

How concerned are you, if at all, that global climate change will harm you personally at some point in your lifetime?

- Very concerned

- Somewhat concerned
Deutschland zu wenig oder zu viel Kontrolle darüber gibt, ob und wie viel es seinen Ausstoß von Kohlendioxid $\left(\mathrm{CO}_{2}\right)$ verringert?

- Keine Kontrolle

- Zu wenig Kontrolle

- Genügend Kontrolle

- Zu viel Kontrolle
Glauben Sie, dass der Klimawandel den Menschen bereits heute weltweit schadet, den Menschen erst in den nächsten paar Jahren weltweit schaden wird, den Menschen für viele Jahre nicht schaden wird, oder den Menschen nie schaden wird?

- Den Menschen nie schaden wird

- Den Menschen für viele Jahre nicht schaden wird

- Den Menschen erst in den nächsten paar Jahren weltweit schaden wird

- Der Klimawandel den Menschen bereits heute weltweit schadet

Ist Ihrer Ansicht nach der Klimawandel ein sehr ernstes Problem, relativ ernstes Problem, nicht zu ernstes Problem oder gar kein Problem?

- Gar kein Problem

- Nicht zu ernstes

- Relativ ernstes

- Sehr ernstes

Wie besorgt sind Sie, falls überhaupt, dass der Klimawandel Ihnen persönlich im Verlauf Ihres Lebens schaden wird? Sind Sie sehr besorgt, etwas besorgt, nicht zu besorgt, oder gar nicht besorgt?

- Sehr besorgt 


\begin{tabular}{|c|c|}
\hline $\begin{array}{l}\text { - Not too concerned } \\
\text { - Not at all concerned }\end{array}$ & $\begin{array}{l}\text { - Etwas besorgt } \\
\text { - Nicht zu besorgt } \\
\text { - Gar nicht besorgt }\end{array}$ \\
\hline \multicolumn{2}{|l|}{ Interest in international politics } \\
\hline $\begin{array}{l}\text { How interested are you in international politics? } \\
\text { • Extremely interested } \\
\text { • Very interested } \\
\text { - Somewhat interested } \\
\text { - Not at all interested• }\end{array}$ & $\begin{array}{l}\text { Wie interessiert sind Sie an internationaler Politik? } \\
\text { • Überhaupt nicht interessiert } \\
\text { • Etwas interessiert } \\
\text { - Sehr interessiert } \\
\text { - Extrem interessiert }\end{array}$ \\
\hline \multicolumn{2}{|l|}{ Self-Described Understanding of Treatments } \\
\hline $\begin{array}{l}\text { Now that you have read the description at the beginning of the survey, how } \\
\text { well do you understand what the Global Climate Conference is and how it } \\
\text { works? } \\
\text { - Not at all } \\
\text { - A bit } \\
\text { - To some extent } \\
\text { - Well } \\
\text { - Very well }\end{array}$ & $\begin{array}{l}\text { Nach dem Lesen und Beantworten dieser Umfrage, wie gut verstehen Sie aus } \\
\text { Ihrer Sicht, was auf der Weltklimakonferenz passiert und wie diese } \\
\text { funktioniert? } \\
\text { • Verstehe sehr gut } \\
\text { - Verstehe ziemlich gut } \\
\text { • Verstehe einigermassen } \\
\text { - Verstehe überhaupt nicht }\end{array}$ \\
\hline \multicolumn{2}{|c|}{$\begin{array}{l}\text { Mechanisms } \\
\text { Please tell us whether you agree, somewhat agree, somewhat disagree or disagree with the following statement. Order randomized participants }\end{array}$} \\
\hline It does not matter how negotiations are conducted and what the voting rules & Die Weltklimakonferenz ist zu wirkungslos, um den Klimawandel zu \\
\hline
\end{tabular}




\begin{tabular}{|c|c|}
\hline are, the Global Climate Conference is too ineffective to stop climate change. & $\begin{array}{l}\text { stoppen, egal wie die Verhandlungen durchgeführt werden und wie die } \\
\text { Abstimmungs- und Umsetzungsregeln lauten. }\end{array}$ \\
\hline $\begin{array}{l}\text { No country should be pressured into reducing its carbon dioxide }\left(\mathrm{CO}_{2}\right) \\
\text { emissions if it does not want to. }\end{array}$ & $\begin{array}{l}\text { Kein Land sollte unter Druck gesetzt werden, seinen Kohlendioxidausstoß zu } \\
\text { reduzieren, wenn es dazu nicht bereit ist. }\end{array}$ \\
\hline $\begin{array}{l}\text { The Global Climate Conference creates strong pressure on the United States } \\
\text { to act against climate change. }\end{array}$ & $\begin{array}{l}\text { Die Weltklimakonferenz setzt Deutschland unter starken Druck, etwas gegen } \\
\text { den Klimawandel zu tun. }\end{array}$ \\
\hline $\begin{array}{l}\text { An international body, in which many countries are involved, should not be } \\
\text { allowed to tell the United States what to do. }\end{array}$ & $\begin{array}{l}\text { Einer internationalen Konferenz, an der viele andere Staaten beteiligt sind, } \\
\text { sollte nicht gestattet sein, Deutschland vorzuschreiben, was es tun muss. }\end{array}$ \\
\hline $\begin{array}{l}\text { The climate change problem can only be solved if the Global Climate } \\
\text { Conference has the authority to decide how much each country must reduce } \\
\text { its carbon dioxide emissions even if it's against the will of the United States. }\end{array}$ & $\begin{array}{l}\text { Das Problem des Klimawandels kann nur gelöst werden, wenn die } \\
\text { Weltklimakonferenz frei entscheiden kann, wie viel Kohlendioxidausstoß } \\
\text { jeder Staat reduzieren muss, wenn nötig auch gegen den Willen } \\
\text { Deutschlands. }\end{array}$ \\
\hline The Global Climate Conference is undemocratic. & Die Weltklimakonferenz ist undemokratisch. \\
\hline \multicolumn{2}{|l|}{ YouGov Demographic Questions } \\
\hline In what year were you born? & In what year were you born? \\
\hline Are you male or female? & Bitte geben Sie Ihr Geschlecht an. ( männlich/weiblich) \\
\hline Thinking back over the last year, what was your family's annual income? & Wie hoch war das durchschnittliche Monatseinkommen Ihres Haushalts vor \\
\hline
\end{tabular}




\begin{tabular}{|c|c|}
\hline $\begin{array}{l}\text { - Less than } \$ 10,000 \\
\text { - } \$ 10,000 \text { - } \$ 19,999 \\
\text { - } \$ 20,000 \text { - } \$ 29,999 \\
\text { - } \$ 30,000 \text { - } \$ 39,999 \\
\text { - } \$ 40,000 \text { - } \$ 49,999 \\
\text { - } \$ 50,000 \text { - } \$ 59,999 \\
\text { - } \$ 60,000 \text { - } \$ 69,999 \\
\text { - } \$ 70,000 \text { - } \$ 79,999 \\
\text { - } \$ 80,000 \text { - } \$ 99,999 \\
\text { - } \$ 100,000 \text { - } \$ 119,999 \\
\text { - } \$ 120,000 \text { - } \$ 149,999 \\
\text { - Prefer not to say }\end{array}$ & $\begin{array}{l}\text { Steuern in den vergangenen } 12 \text { Monaten? Bitte zählen Sie hierzu Einkünfte } \\
\text { aus Lohn, Gehalt, selbständiger Tätigkeit, Rente, Pension, jeweils ohne } \\
\text { Abzug der Steuern und Sozialversicherungsbeiträge. Rechnen Sie bitte auch } \\
\text { die Einkünfte aus öffentlichen Beihilfen, Einkommen aus Vermietung, } \\
\text { Verpachtung, Wohngeld, Kindergeld und sonstige Einkünfte hinzu. } \\
\text { • Weniger als } 750 \text { Euro } \\
\text { - } 750 \text { bis unter } 1.250 \text { Euro } \\
\text { - } 1.250 \text { bis unter } 1.750 \text { Euro } \\
\text { - } 1.750 \text { bis unter } 2.250 \text { Euro } \\
\text { - } 2.250 \text { bis unter } 2.750 \text { Euro } \\
\text { - } 2.750 \text { bis unter } 3.250 \text { Euro } \\
\text { - } 3.250 \text { bis unter } 3.750 \text { Euro } \\
\text { - } 3.750 \text { bis unter } 4.250 \text { Euro } \\
\text { - } 4.250 \text { bis unter } 4.750 \text { Euro } \\
\text { - } 4.750 \text { bis unter } 5.250 \text { Euro } \\
\text { • } 5.250 \text { bis unter } 5.750 \text { Euro } \\
\text { - } 5.750 \text { bis unter } 6.250 \text { Euro } \\
\text { - } 6.250 \text { Euro und meh }\end{array}$ \\
\hline In which state do you live? & In welchem Bundesland leben Sie? \\
\hline $\begin{array}{l}\text { In general, how would you describe your own political viewpoint? } \\
\text { - Very liberal } \\
\text { - Liberal } \\
\text { - Moderate } \\
\text { - Conservative } \\
\text { - Very conservative } \\
\text { - Not sure }\end{array}$ & $\begin{array}{l}\text { In der Politik spricht man von "links" und "rechts". Wie würden Sie } \\
\text { persönlich Ihren politischen Standpunkt auf dieser Liste einordnen? (1 to 10) }\end{array}$ \\
\hline What racial or ethnic group best describes you? & \\
\hline
\end{tabular}




\begin{tabular}{|c|c|}
\hline $\begin{array}{l}\text { - White } \\
\text { - Black or African-American } \\
\text { - Hispanic or Latino } \\
\text { - Asian or Asian-American } \\
\text { - Native American } \\
\text { - Middle Eastern } \\
\text { - Mixed Race } \\
\text { - Other (please specify) }\end{array}$ & \\
\hline $\begin{array}{l}\text { What is the highest level of education you have completed? } \\
\text { - Did not graduate from high school } \\
\text { - High school graduate } \\
\text { - Some college, but no degree (yet) } \\
\text { - 2-year college degree } \\
\text { - 4-year college degree } \\
\text { - Postgraduate degree (MA, MBA, MD, JD, PhD, etc.) }\end{array}$ & $\begin{array}{l}\text { Welchen höchsten Schulabschluss haben Sie? } \\
\text { - } \text { - Hoch in schulischer Ausbildung } \\
\text { - } \text { Realschul- oder gleichwertiger Abschluss (POS, Mittlere Reife) } \\
\text { - } \text { Abitur, Fachhochschulreife } \\
\text { - } \text { Ohne Schulabschluss } \\
\text { Weine Angabe } \\
\text { - Keinen Abschluss } \\
\text { - Noch in Ausbildung } \\
\text { - Noch im Studium } \\
\text { - Lehre oder vergleichbarer Abschluss } \\
\text { - Universitäts- oder Fachhochschulabschluss } \\
\text { - keine Angabe } \\
\text { Wann haben stoppen Sie Ihre Ausbildung? } \\
\text { - } 15 \text { oder jünger } \\
\text { - } 16 \\
\text { - } 17-18 \\
\text { - } 20 \text { oder älter }\end{array}$ \\
\hline
\end{tabular}




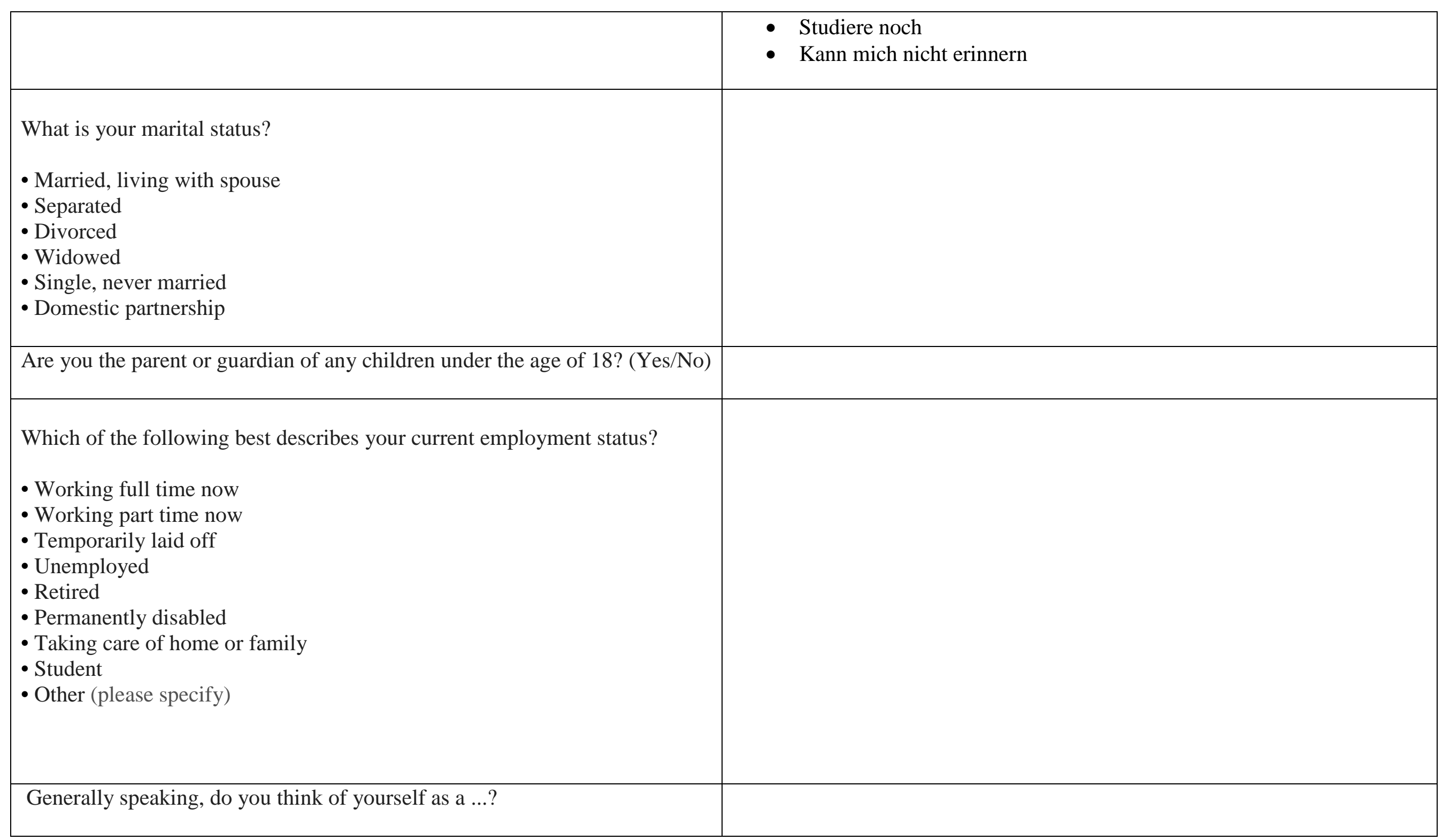




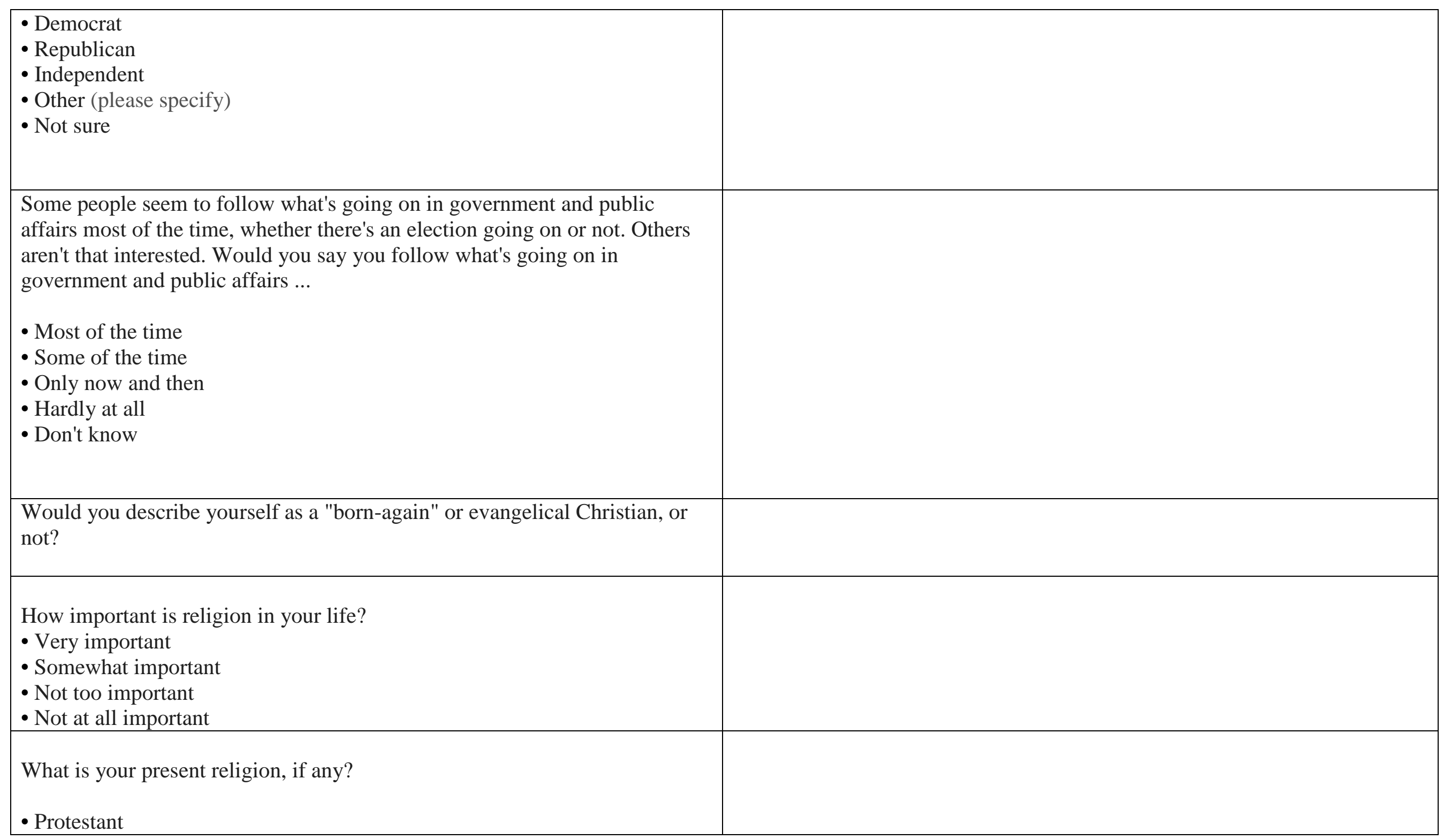




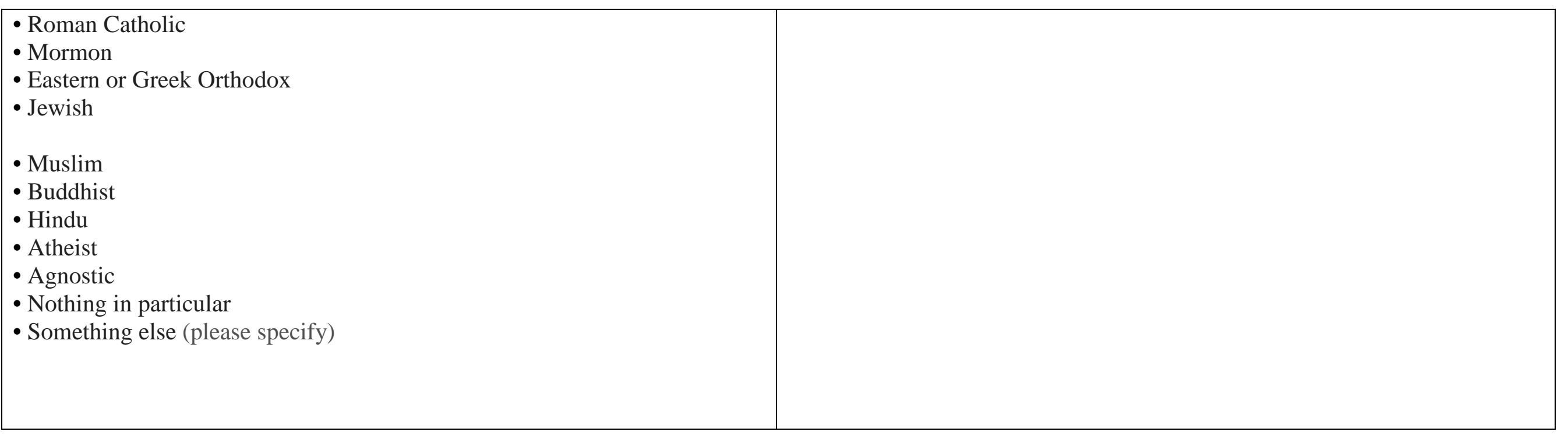




\section{SI 8: Robustness checks}

Insignificant treatment effects could be problematic because of possible false negatives (type II error). Hence, we engage in several robustness checks. One potential concern could be the complexity of the issue to which survey participants are exposed. Under such conditions, insignificant results might stem from participants' inability to understand the context, the treatments, and the dependent variable items. In the worst case, this could result in participants providing socially desirable answers to our legitimacy items irrespective of treatment conditions. The combination of "noisy" treatments and ceiling effects due to social desirability bias on dependent variable items would then result in insignificant treatment effects.

We are able to refute this potential concern by estimating all models with samples excluding respondents who incorrectly answered one or more of the comprehension questions by their second attempt. The results remain the same for the direct effects. For the moderating effects, we find the same significant interaction between treatments and cognitive mobilization. Those who are more cognitively mobilized in the US sample perceive Majority-Automatic as more legitimate than Consensus-Legislature in the reduced sample. For the moderating effect of climate concern, we find similar results, specifically, no significant interaction effect between authority and climate concern on legitimacy beliefs.

Moreover, one might argue that answering a comprehension check question correctly by the second attempt could be luck and not truly reflect actual understanding of the treatment. To assess this possibility, we conducted analyses on the sample of participants who answered the three comprehension questions correctly by their second attempt and whose self-reported understanding to the question, Now that you have read the description at the beginning of the survey, how well do you understand what the Global Climate Conference is and how it works, was either well or very well. For the analyses of the main effects and moderating effects for those who are extremely interested we obtain the same results. The results of these robustness checks support the conclusion that our results are unlikely to be artifacts of participants' incomprehension of the policy context or the treatments. Moreover, the results for the manipulation check demonstrate that the treatments were effective in the sense of treated participants being aware of shifted authority, and in the sense of, their country losing at least some control over the policymaking process.

Another potential concern might be that our dependent variables fail to accurately measure legitimacy perceptions. The existing literature tends to use trust and confidence, which, as noted earlier, are necessary conditions for legitimacy but not sufficient. Moreover, relying on individual survey items, rather than scales consisting of several items, increases the risk of measurement error. Therefore, we carried out analyses with the 5-ITEM dependent variable in order to capture different facets of legitimacy. In addition, the 5-ITEM measure is not skewed towards high perceived legitimacy levels, unlike APPROPRIATE and DEFERENCE, making ceiling effects unlikely. The results remained unchanged when using the 5-ITEM measure. Given the robustness of the results using the two single-item measures and the composite dependent variable, our findings are quite robust.

To assess the robustness of the observed effect of authority level on perceived legitimacy amongst more cognitively mobilized individuals in the US, we use another measure of cognitive mobilization. We conducted ordinal logistic regressions for the full and reduced samples, with APPROPRIATE and DEFERENCE as well as the 5-ITEM measure as dependent variables. The results indicate that those with a high school education in the full US sample find 
the climate governance framework with legislature approval more legitimate than automatic implementation. Likewise, those with some college find automatic implementation more legitimate than legislature approval. Overall, these results confirm the findings reported further above (see SI-4 (b)).

The evidence from the core part of our survey experiment shows that the mass public is able to understand the implications of pooling authority internationally. However, shifting authority does not seem to significantly affect citizen's legitimacy perceptions with respect to the climate governance framework. 